\title{
Behavior of Mercury and lodine During Vitrification of Simulated Alkaline Purex Waste
}

L. K. Holton

September 1981

Prepared for the U.S. Department of Energy under Contract DE-AC06-76RLO 1830

Pacific Northwest Laboratory Operated for the U.S. Department of Energy by Battelle Memorial Institute 

BEHAVIOR OF MERCURY AND IODINE DURING VITRIFICATION OF

SIMULATED ALKALINE PUREX WASTE

L. K. Holton

September 1981

Prepared for the U.S. Department of Energy under Contract DE-AC06-76RLO-1830

Pacific Northwest Laboratory Richland, Washington 99352 
.

: 


\section{ACKNOWLEDGMENTS}

Considerable effort from other PNL researchers was required to conduct this experimental study. The author appreciates the assistance from F. E. Haun in conducting the experiments, J. E. Coleman in performing the x-ray microprobe and SEM analyses,. H. E. Kissinger in performing the x-ray diffraction analyses, F. T. MCBarron in performing the ion chromatography analyses, J. H. Reeves in performing the neutron activation analyses and $F$. T. Hara in performing the ICP and $x$-ray fluorescence analysis. The author also wishes to thank M. A. Eierdam and V. M. Groves for their skillful assistance in preparing this report. 


\section{CONTENTS}

ACKNOWLEDGMENTS

i i i

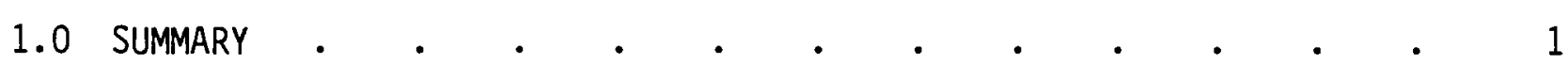

2.0 INTRODUCTION

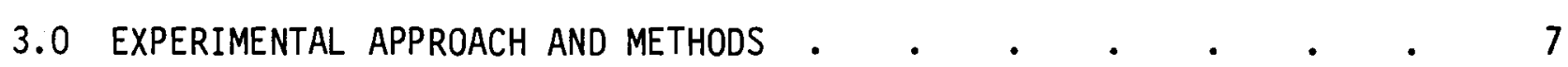

3.1 EXPERIMENTAL DESIGN

3.2 SOLIDIFICATION PROCESS AND EQUIPMENT DESCRIPTION • • • 10

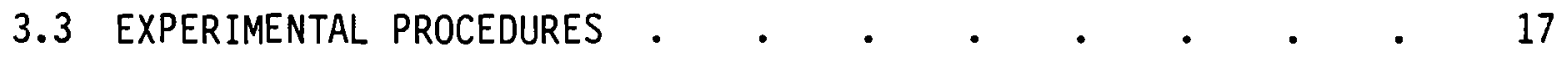

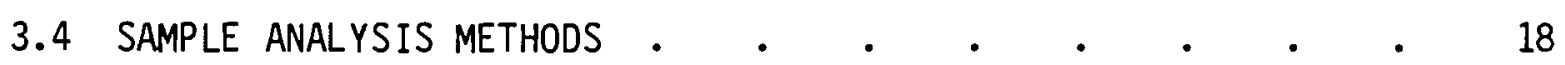

4.0 EXPERIMENTAL RESULTS $\quad$.

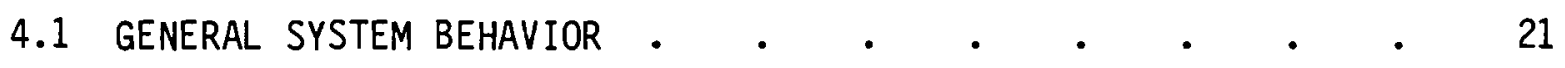

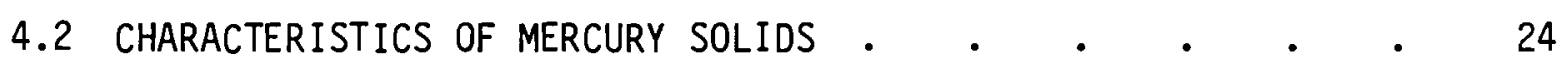

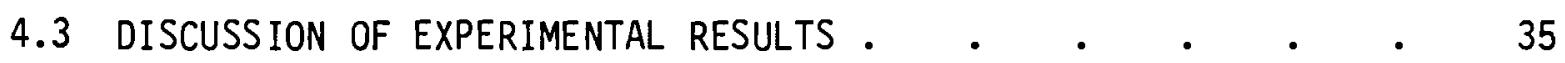

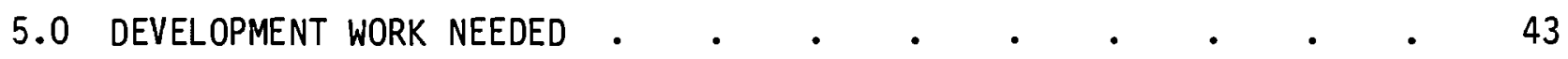

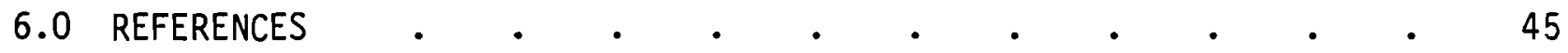

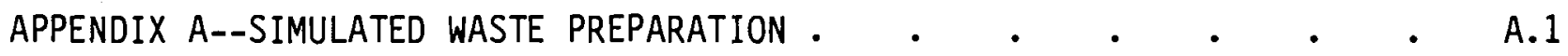

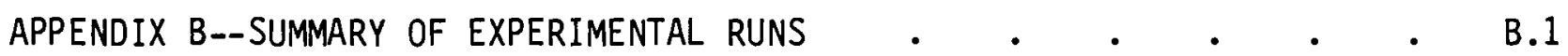




\section{FIGURES}

3.1 Yates $2^{3}$ Experimental Design for Mercury Study . . . . 7

3.2 Free Energy Versus Temperature of Various Mercury Compounds

B-Boiling Temperature, M-Melting Temperature, D-Decomposition

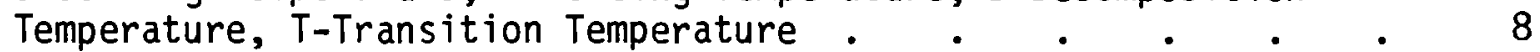

3.3 Reaction Equilibrium Between Mercury and Iodine . . . . 9

3.4 Schematic of Experimental System for Mercury Study . . . . 11

3.5 Schematic of Venturi Scrubber . . . . . . . 15

3.6 Schematic of Cyclone Scrubber . . . . . . . 16

4.1 Percent Iodide Retention in Glass for Experiments Performed

4.2 Mercury Composition of Off-Gas Solids Collected During 28

4.3 Iodide Composition of Off-Gas Solids Collected During Mercury

Study Experiments . . . • . • . • . . 28

4.4 Chloride Composition of Off-Gas Solids Collected During Mercury

Study Experiments . . . . . . . . . . 29

4.5 X-Ray Micrograph of Venturi Solid Sample Feature (Point Number 1)

from Experiment No. $1 . \quad . \quad . \quad . \quad . \quad . \quad . \quad . \quad$.

4.6 X-Ray Micrograph of Venturi Solid Sample Feature (Point Number 2)

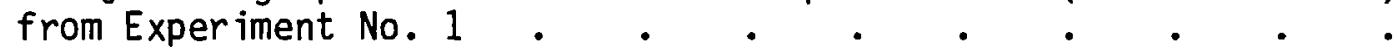

4.7 X-Ray Micrograph of Venturi Solid Sample General Area Scan from

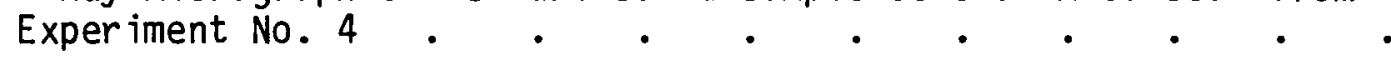

4.8 X-Ray Micrograph of Venturi Solid Sample Amorphous Feature

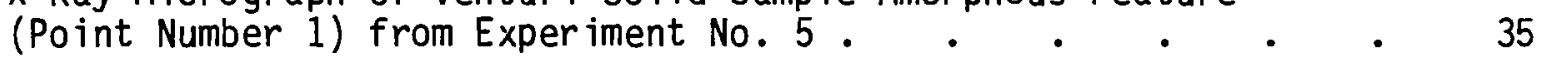

4.9 X-Ray Micrograph of Venturi Solid Sample Flat Feature

(Point Number 2) from Experiment No. 5 . . . . • . 36

4.10 X-Ray Micrograph of Venturi Solid Sample, HgI Particle

from Experiment No. 7 (Point Number 1) . . . . . . 
4.11 X-Ray Micrograph of Venturi Solid Sample, HgCl Particle

from Experiment No. 7 (Point Number 2) . . . . . . 38

4.12 X-Ray Micrograph of Venturi Solid Sample and General Area

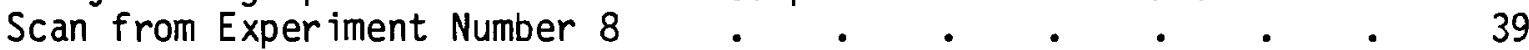

$\underline{\text { TABLES }}$

2.1 Major Components of SRP High-Level Waste Sludges . . $_{4} \quad$ • 4

3.1 Summary of Design Features of the Laboratory Scale Spray Calciner/

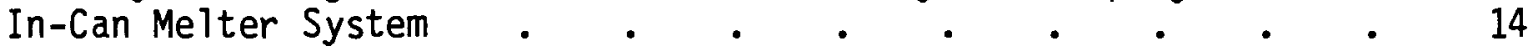

3.2 Analysis Methods for Samples Collected During Mercury Study 19

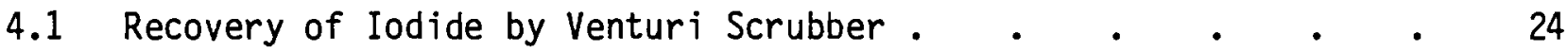

\begin{tabular}{l} 
4.2 Characteristics of Mercury Solids Recovered from Venturi \\
Scrub Tank \\
\hline
\end{tabular}

PHOTOGRAPHS

3.1. Photograph of Laboratory Scale Spray Calciner/In-Can Melter

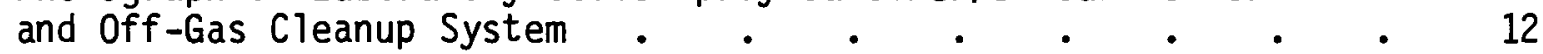

4.1. Photograph of Mercury Solids Collected From Venturi. Solution, Experiment No. 1 Showing $\mathrm{HgCl}$ and $\mathrm{HgI}$ particulate $(10,000 \mathrm{X})$

4.2. Photograph of Mercury Solids Collected From Venturi Solution, Experiment No. 4 Showing Crystalline $\mathrm{HgCl}(3,000 \mathrm{X})$. . . 32

4.3. Photograph of Mercury Solids Collected From Venturi Solution, Experiment No. 5 Showing Mercury Metal and $\mathrm{HgI}(10,000 \mathrm{X})$. . 34

4.4. Photograph of Mercury Solids Collected From Venturi Solution, Experiment No. 7 Showing $\mathrm{HgCl}$ and $\mathrm{HgI}$ Particulate $(10,000 \mathrm{X})$

4.5. Photograph of Mercury Solids Collected From Venturi Solution, Experiment No. 8 Showing HgI Particulate $(10,000 \mathrm{X})$. . 


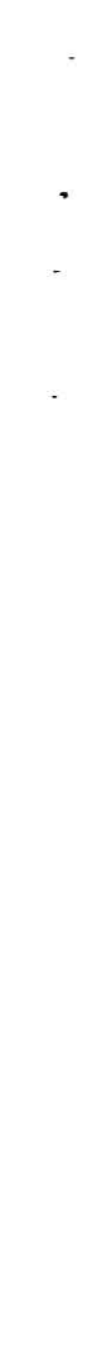




\subsection{SUMMARY}

Current plans indicate that the high-level wastes stored at the Savannah River Plant (SRP) will be solidified by vitrification. The behavior of mercury and iodine during the vitrification process is of concern because: mercury is present in the waste in high concentrations (0.1 to $2.8 \mathrm{wt} \%)$; mercury will react with iodine and the other halogens present in the waste during vitrification and; the mercury compounds formed will be volatilized from the vitrification process placing a high particulate load in the vitrification system off-gas.

Twe lve experiments were completed to study the behavior of mercury during vitrification of simulated SRP Purex waste. Three independent variables, forming eight nodes in a $2^{3}$ experimental design were varied for experimentation. Four experiments were repeated to improve experimental reliability. Experimental variables and bounding values were: 1) the iodide to mercury molar ratio in the simulated waste set at 0.1 and $0.9,2$ ) the vitrification system outlet gas temperature set at $300^{\circ} \mathrm{C}$ and $600^{\circ} \mathrm{C}$, and 3 ) the oxygen content of the vitrification system atmosphere set at approximately zero volume percent and twenty volume percent. These experimental variables with bounding values are anticipated to form the bounds for process conditions in actual plant operations.

The experiments were conducted using a laboratory scale spray calciner/ in-can melter system and vitrification off-gas cleanup system. The off-gas cleanup system consisted of a venturi scrubber, cyclone, downdraft condenser, off-gas heater and a HEPA filter. Simulated alkaline Purex waste was prepared by precipitation of metallic nitrates and batch washing of the resultant sludge to remove soluble salts. Simulated waste prepared by this method is believed to duplicate as accurately as possible the chemical behavior of actual alkaline Purex waste.

The mercury was completely volatized from the vitrification system in all experiments. The mercury reacted with iodine, chlorine and oxygen to form a fine particulate solid. Quantitative recovery of mercury compounds formed in 
the vitrification system off-gas was not possible due to high (37 to $90 \%$ ) deposition of solids in the off-gas piping.

The behavior of mercury and iodine was most strongly influenced by the vitrification system atmosphere. During experiments performed in which the oxygen content of the vitrification system atmosphere was low ( $<1 \mathrm{vol \%}$ ); iodine retention in the glass product was 27 to 55\%, the mercury composition of the solids recovered from the off-gas scrub solutions was 75 to $85 \mathrm{wt} \%$, and a small quantity of metallic mercury was recovered from the off-gas scrub solution. During experiments performed in which the oxygen content of the vitrification system atmosphere was high ( $20 \mathrm{vol} \%$ ), iodide retention in the glass product was 3 to $15 \%$, the mercury composition of the solids recovered from the off-gas scrub solutions, was 60 to $80 \mathrm{wt} \%$, and very little metallic mercury was recovered from the off-gas scrub solution.

The kinetics of reaction between iodine and mercury was concluded to be fast. However, there is competition between chlorine and iodine for reaction with mercury. The reaction between mercury and iodine was complete when there was a low ratio of iodide to mercury $(0.10)$ in the simulated waste feed; the reaction was only partially complete ( $\sim 50$ to $90 \%$ ) when the iodide to mercury ratio in the simulated waste was high $(0.90)$.

From the experimental work conducted we have identified the need for further study. Areas needing attention are:

- Buildup of the mercury solids in the off-gas piping during long-term equipment operations.

- Develop processes for quantitative recovery of mercury from the alkaline Purex waste prior to vitrification.

- Separation of mercury solids from the scrub solutions and recovery of mercury from the solids.

- Assessment of corrosion by mercury and mercury compounds on the vitrification and off-gas equipment. 


\subsection{INTRODUCTION}

Nuclear fuels reprocessed by the Savannah River Plant (SRP) over a span of 25 years have produced approximately $9.0 \times 10^{4} \mathrm{~m}^{3}$ of alkaline high-level radioactive wastes. These wastes consist of liquid ( 58 vol\%), salt cake ( 29 vol\%) and sludge ( 13 vol\%).

The stored SRP wastes, which are mainly the product of two processing schemes, can be roughly grouped into high-iron- and high-aluminum-containing wastes. A Purex process, operated in the SRP F Area, produced a waste containing high concentrations of iron. In addition, coating waste, obtained from decladding targets that were processed in $F$ Area, added high concentrations of aluminum and mercury to the $F$ Area waste tanks. A modified Purex process in the SRP $H$ Area was used to process aluminum clad uranium fuel. Both the aluminum cladding and uranium were codissolved using mercury as a dissolution catalyst. The resultant HAW waste contains high aluminum concentrations while the LAW waste from the process is similar to Purex waste and has high concentrations of iron. Major chemical and radiochemical components of the $F$ Area and $H$ Area high-level waste sludges are summarized in Table 2.1.

Current plans indicate that these high-level wastes will be solidified by vitrification. The behavior of mercury during the vitrification process is of concern because of the high concentration of mercury in the wastes $(0.1$ to $2.8 \mathrm{wt} \%$ ) and the fact that mercury and mercury compounds will be volatilized from the vitrification process thus placing a high particulate load in the vitrification off-gas.

Only limited information is presently available on the behavior of mercury and its interaction with iodine in the vitrification process. This information is limited to simple experimental studies directed towards characterization of the recombination kinetics of mercury and iodine, and thermodynamic computer studies directed towards predicting the chemical form of mercury in the vitrification system off-gas(G. B. Woolsey, Savannah River Laboratory). 
TABLE 2.1. Major Components of SRP High-Level Waste Sludges(a)

\begin{tabular}{|c|c|c|}
\hline \multirow[b]{2}{*}{ Const ituent } & \multicolumn{2}{|c|}{ Concentration Range (wt\%) } \\
\hline & F Area & HArea \\
\hline A1 & 1.5 to 2.5 & 7.1 to 33.5 \\
\hline $\mathrm{Ca}$ & 0.6 to 2.3 & 0.2 to 2.9 \\
\hline $\mathrm{Fe}$ & 8.9 to 32.8 & 3.1 to 27.9 \\
\hline $\mathrm{Hg}$ & 0.1 to 0.7 & 0.9 to 2.8 \\
\hline$M n$ & 2.0 to 10.8 & 1.7 to 8.8 \\
\hline $\mathrm{Na}$ & 2.8 to 6.1 & 1.0 to 3.1 \\
\hline $\mathrm{Ni}$ & 2.1 to 6.3 & 0.3 to 0.7 \\
\hline $\mathrm{NO}_{3}$ & 0.12 to 1.2 & 0.2 to 0.4 \\
\hline $\mathrm{NO}_{2}$ & 0.02 to 0.12 & 0.01 to 0.2 \\
\hline $\mathrm{SO}_{4}$ & $<0.5$ & $<0.05$ \\
\hline$U$ & 3.3 to 15.4 & 0.9 to 4.5 \\
\hline
\end{tabular}

\begin{tabular}{|c|c|c|}
\hline \multirow{2}{*}{$\frac{\text { Radionuclide }}{{ }^{144} \mathrm{Ce}}$} & \multicolumn{2}{|c|}{$\frac{\text { Activity Range (mCi/g of sludge) }}{\text { FArea }}$} \\
\hline & 0.21 to 30.5 & 0.3 to 17.4 \\
\hline 60 & 1 to 1 & 0.01 to 0.06 \\
\hline & 0.01 to $<0.02$ & $<0.01$ to 0.03 \\
\hline & 0.7 to 1.30 & 0.05 to 0.30 \\
\hline & $<0.01$ to 0.6 & 0.08 to 1.18 \\
\hline${ }^{95} \mathrm{Nb}$ & $<0.01$ to $<0.03$ & $\leq 0.02$ \\
\hline $103_{\mathrm{Ru}}$ & $<0.01$ to $<0.02$ & $<0.01$ \\
\hline & 1.3 to 11.4 & 0.08 to 1.74 \\
\hline${ }^{125} \mathrm{Sb}$ & 0.43 & 0.12 to 1.27 \\
\hline${ }^{90} \mathrm{Sr}$ & 27.03 to 177.5 & 15.49 to 55.0 \\
\hline
\end{tabular}

(a) Stone (1976a); Ondrejoin (1974); Gray, Donnan, and Okamoto (1979); Stone (1976b); Stone, Goforth, and Smith (1979). 
The purpose of this experimental study was therefore to characterize the chemical behavior of mercury during vitrification of simulated alkaline SRP waste when key process parameters are varied. The behavior of mercury, as influenced by the three process variables listed below, was studied.

- iodide-to-mercury molar ratio in the simulated SRP waste feed

- vitrification system outlet off-gas temperature

- oxygen $\left(\mathrm{O}_{2}\right)$ concentration in the vitrification system atmosphere. 


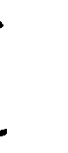




\subsection{EXPERIMENTAL APPROACH AND METHODS}

The experimental methods and system used to conduct the mercury study are summarized in this section. Particular emphasis has been placed on the experimental methods and the experimental system to represent as completely as possible expected waste solidification plant conditions.

\subsection{EXPERIMENTAL DESIGN}

The experimental approach was based on a Yates $2^{3}$ experimental design (Cochran and Cox 1957) shown in Figure 3.1. The three study variables (iodide to mercury molar ratio, temperature of vitrification system off-gas and oxygen concentration of vitrification off-gas) form eight nodes in the $2^{3}$ experimental design. The iodide-to-mercury ratio in the simulated waste was controlled at 0.10 and 0.90 along each of two experimental planes, the off-gas outlet temperature of the vitrification system was controlled at $300^{\circ} \mathrm{C}$ and $600^{\circ} \mathrm{C}$ along each of two experimental planes, and the vitrification system

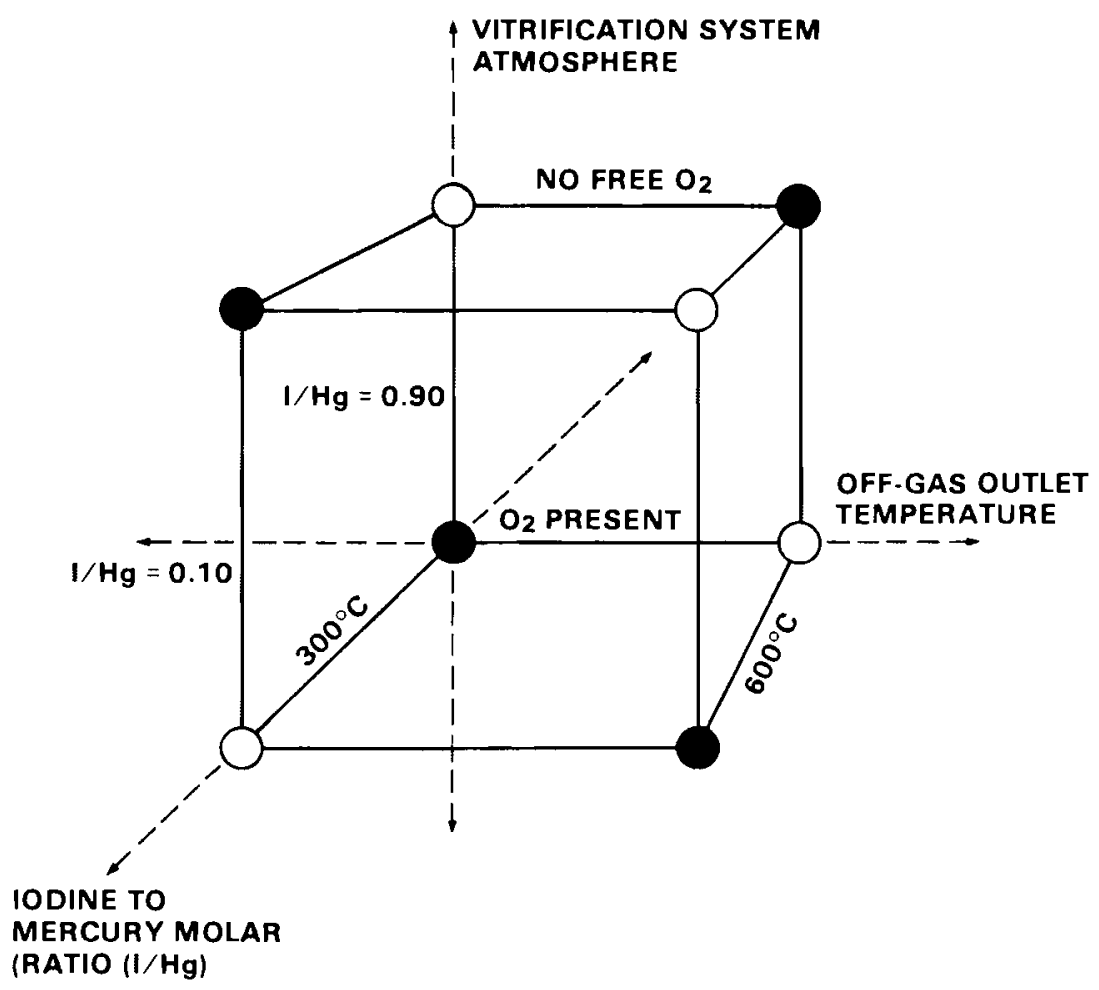

FIGURE 3.1. Yates $2^{3}$ Experimental Design for Mercury Study 
atmosphere was controlled at a condition where virtually no oxygen was present and at a condition where the oxygen concentration was approximately the same as atmospheric concentrations. Four experiments, indicated by the shaded nodes in Figure 3.1 were repeated to improve experimental certainty.

The basis for selecting each of the three experimental variables was the expected difference in chemical behavior of mercury at each experimental node.

Iodine will react with mercury in the gas phase and be condensed as a solid. This reaction pathway can be used to remove volatile iodine from the vitrification off-gas system. The other halogens, chloride and fluoride which are also present in the alkaline waste will react with mercury. Figure 3.2

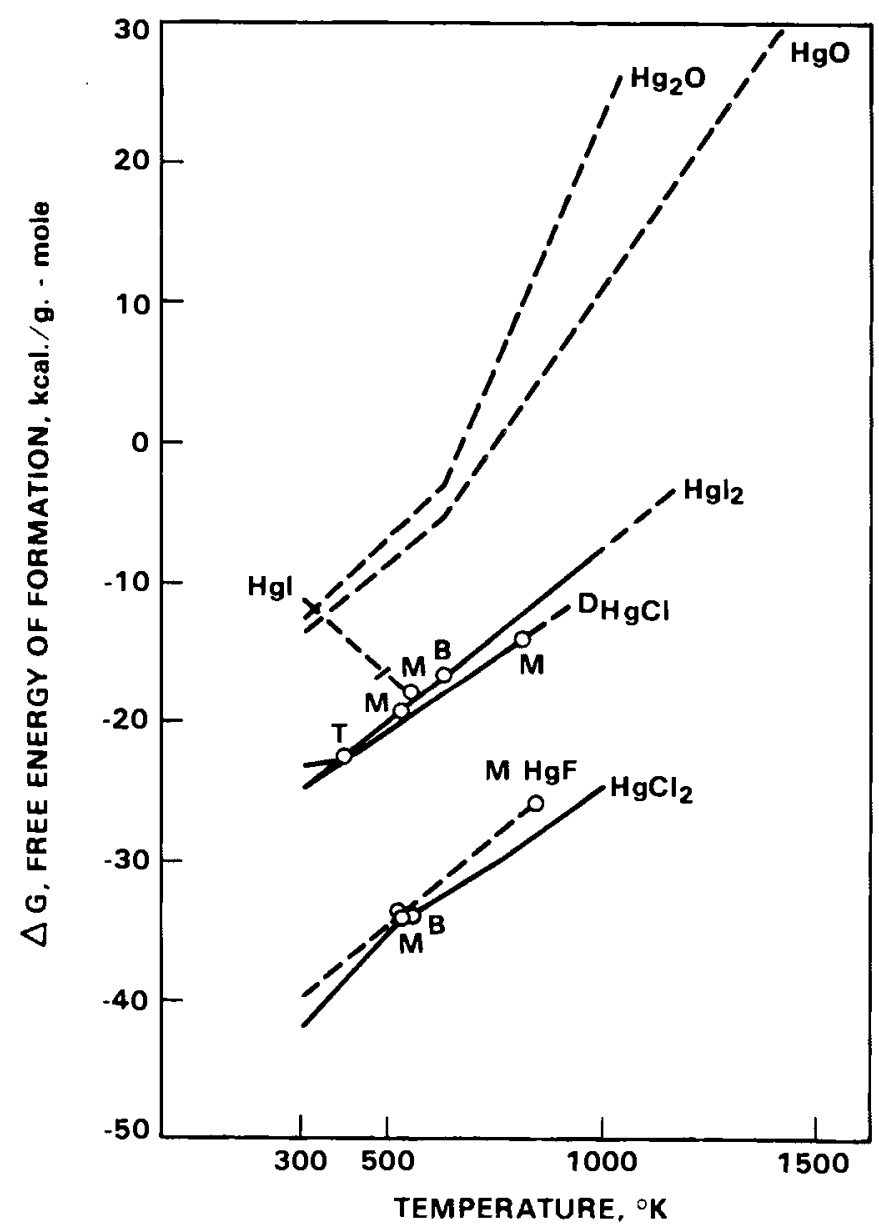

FIGURE 3.2. Free Energy Versus Temperature of Various Mercury Compounds B-Boiling Temperature, M-Melting Temperature D-Decomposition Temperature, T-Transition Temperature. (Adapted from Wicks and Block 1963.) 
depicts graphically the free energy of various mercury compounds as a function of temperature. This data indicates that chloride and fluoride are thermodynamically more favored to react with mercury than iodide. Based upon this data there maybe competition among the various reactants. Evaluating the mercuryiodine reaction at iodide to mercury molar ratios of 0.10 and 0.90 provided information regarding efficiency and competition between reactants. Chloride and fluoride concentrations in the simulated alkaline waste were not intentionally varied for the experiments.

The equilibrium reaction between mercury and iodine is temperature sensitive. A plot of the equilibrium fraction of iodine present in the form $\mathrm{HgI}_{2}$ as a function of temperature is shown in Figure 3.3. This plot indicates that the limiting reactant, iodine, is virtually totally reacted with mercury in the reaction:

$$
\mathrm{Hg}+\mathrm{I}_{2}=\mathrm{HgI}_{2} \text {, (gas phase) }
$$

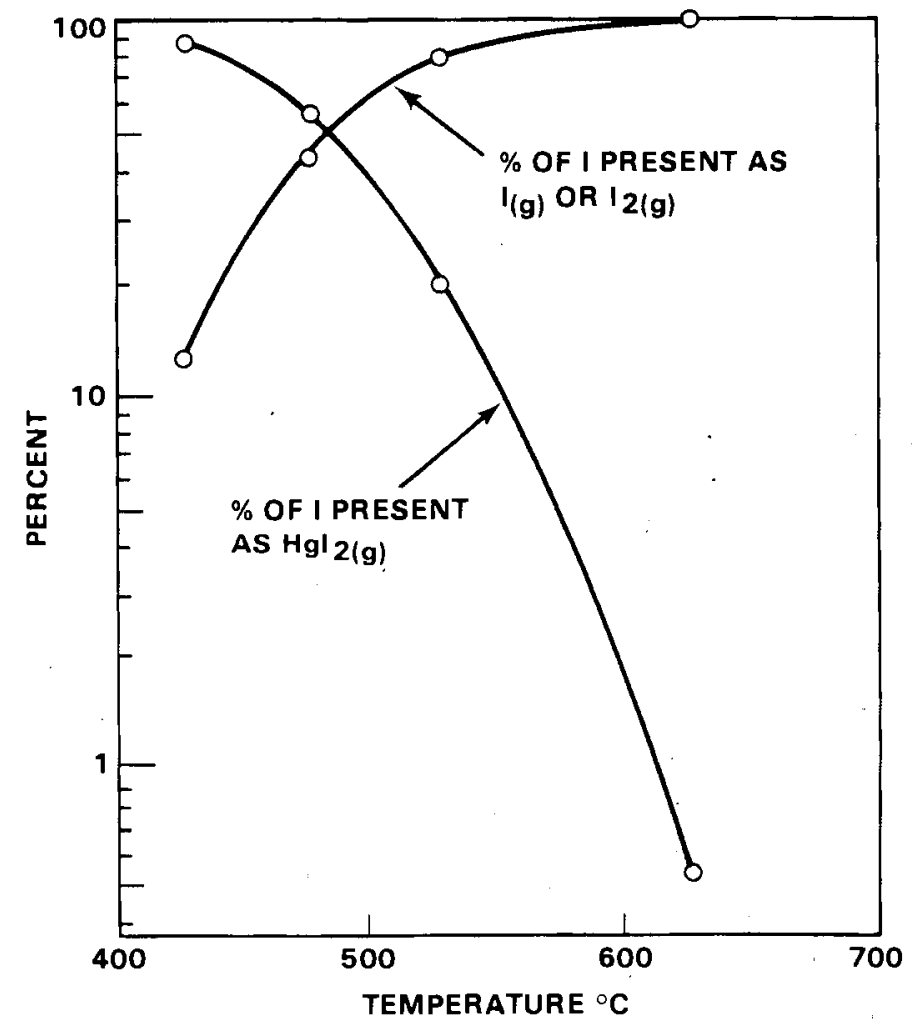

FIGURE 3.3. Reaction Equilibrium Between Mercury and Iodine (Adapted from data in Stul1 and Prophet 1971) 
at temperatures below $350^{\circ} \mathrm{C}$ and is virtually unreacted at temperatures above $600^{\circ} \mathrm{C}$. The reaction product, $\mathrm{HgI}_{2}$, is a covalent vapor molecule in the off gas above its saturation point. The recombination kinetics between $\mathrm{Hg}$ and $\mathrm{I}_{2}$ have been shown to be fast at temperatures below $200^{\circ} \mathrm{C}$ (G. B. Woolsey, Savannah River Laboratory). Based upon this, it is expected that the vitrification system off-gas characteristics at $300^{\circ} \mathrm{C}$ and $600^{\circ} \mathrm{C}$ would be significantly different. However, the off-gas characteristics should be similar after quenching. This, of course, does not consider the interactions of mercury with chloride or fluoride which are also present in the simulated SRP waste. Varying the vitrification system outlet temperature at $300^{\circ} \mathrm{C}$ and $600^{\circ} \mathrm{C}$ will provide information confirming the expected reaction kinetics between mercury and iodine.

The oxygen concentration of the vitrification system atmosphere was varied from containing virtually no oxygen, to containing approximately 20 volume percent oxygen. This experimental variable is evaluated to determine if mercury metal can be formed in and condensed from the vitrification system off-gas in the absence of oxygen. This is an assumption which has been made in the development of Defense Waste Processing Facility (DWPF) flowsheet (Landon 1980).

The three experimental variables (iodide-to-mercury ratio in the simulated waste, off-gas outlet temperature and oxygen concentration of vitrification system atmosphere) are anticipated to form the bounds for process conditions during plant operations. The chemical behavior of mercury and iodine at each of these bounding cases will be evaluated providing information regarding mercury behavior in anticipated plant operations. This information will provide the basis for selection of any alternative waste processing schemes for handling mercury in the DWPF.

\subsection{SOLIDIFICATION PROCESS AND EQUIPMENT DESCRIPTION}

A laboratory scale spray calciner/in-can melter (SC/ICM) and gaseous effluent cleanup system was the waste solidification system used for the mercury study. A simplified schematic of this system is shown in Figure 3.4, and a photograph of the system is shown in Photograph 3.1. The SC/ICM system is comprised of the following major equipment pieces. 


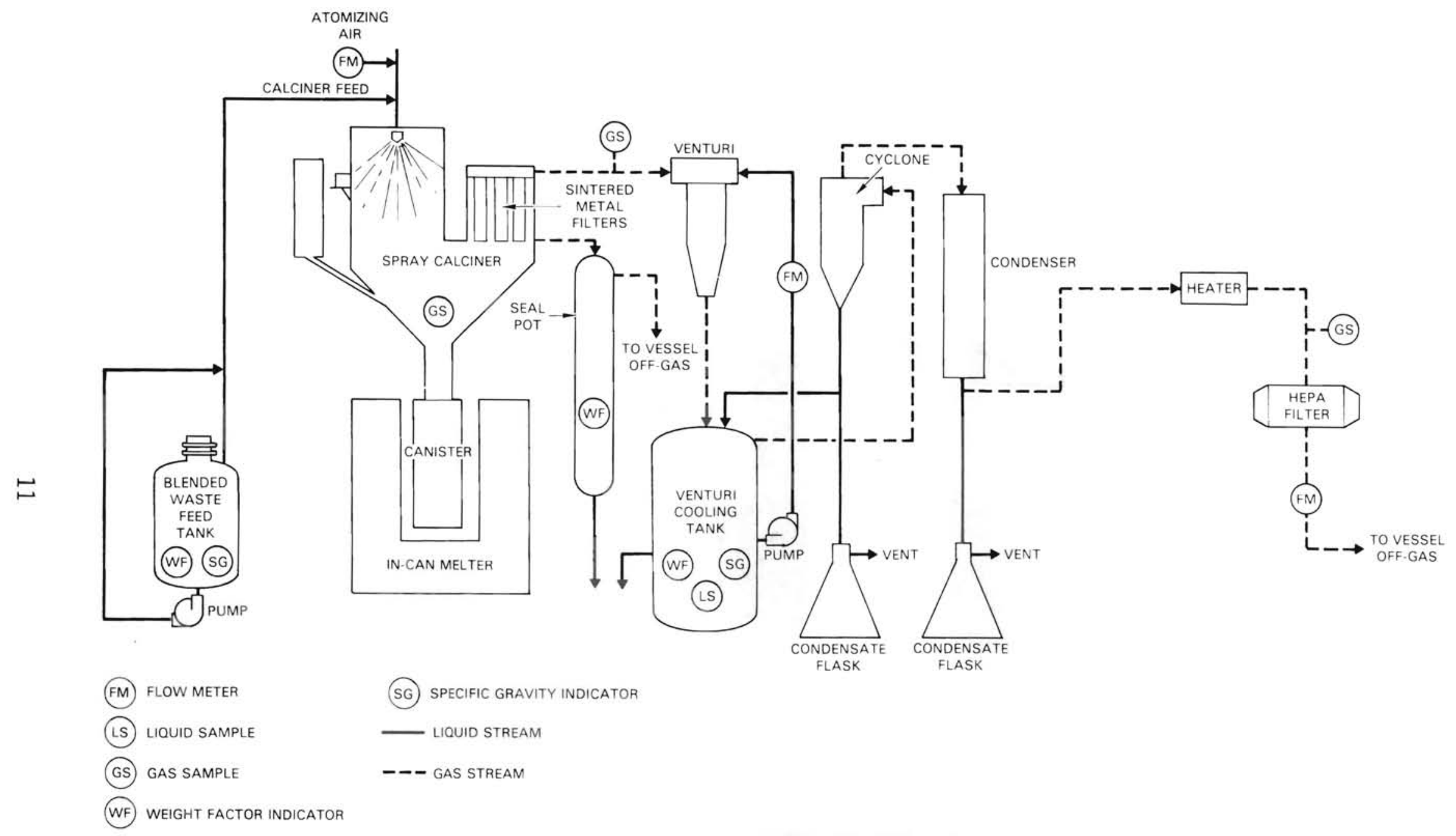

FIGURE 3.4. Schematic of Experimental System for Mercury Study 


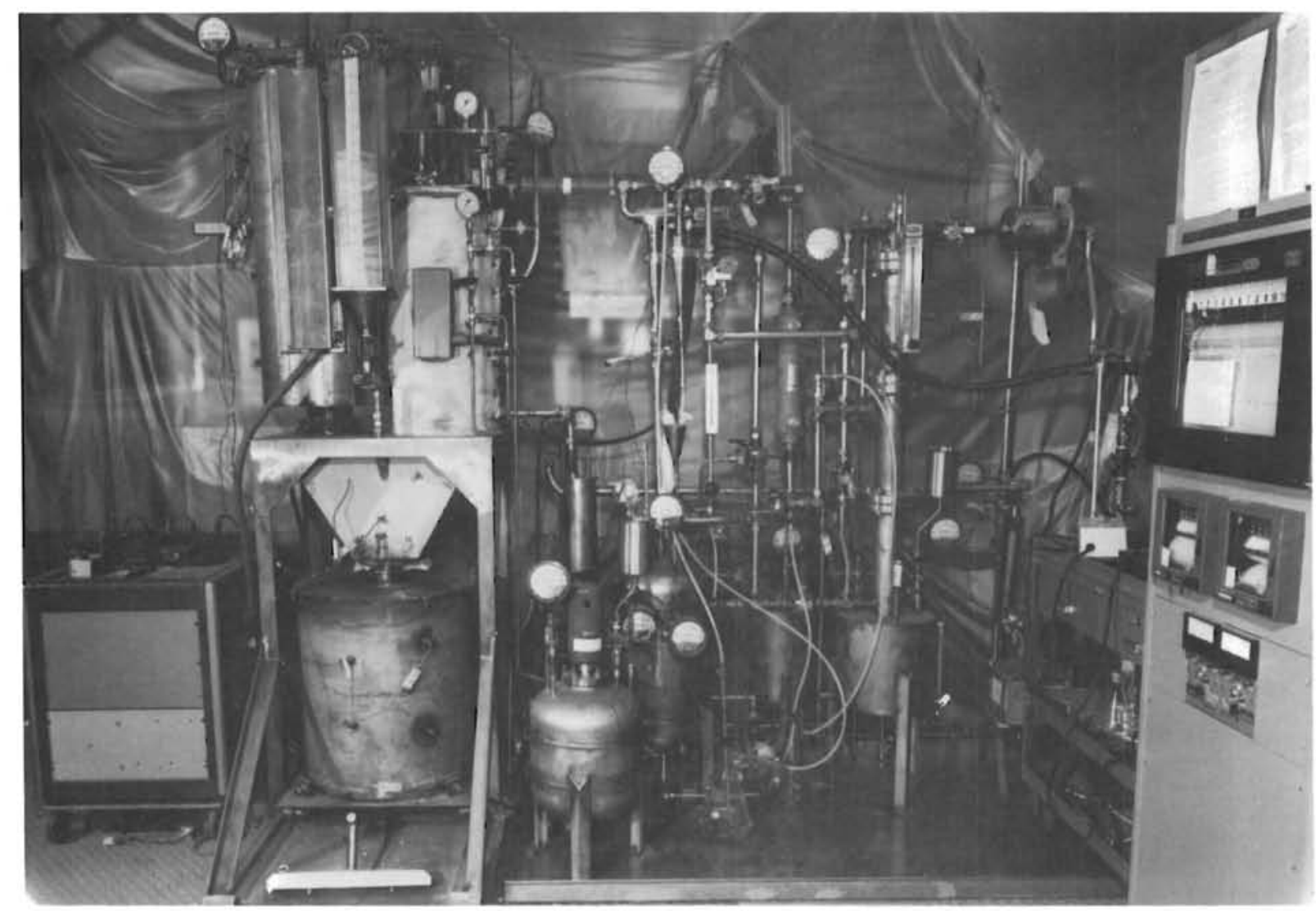

PHOTO 3.1. Photograph of Laboratory Scale Spray Calciner/In-Can Melter and Off-Gas Cleanup System

- liquid waste blend and feed system

- spray calciner/in-can melter

- venturi off-gas scrubber and recycle scrub tank

- cyclone separator and condensate collection flask

- downdraft condenser and condensate collection flask

- off-gas line heater

- HEPA filter

Simulated liquid waste is pumped through the spray calciner feed system and atomized by air in a commercially available spray nozzle (Spraying Systems ${ }^{\circledR}$ nozzle used) located at the top of the spray calciner. Liquid waste droplets

( Registered trademark of Spraying Systems Company. 
( $0.1 \mathrm{~mm} \mathrm{dia)} \mathrm{formed} \mathrm{by} \mathrm{the} \mathrm{spray} \mathrm{nozzle} \mathrm{are} \mathrm{dried} \mathrm{and} \mathrm{partially} \mathrm{decomposed} \mathrm{to}$ metallic oxides and salts as they fall through the heated wall spray calciner chamber. The nominal operating temperature of the spray calciner is 650 to $750^{\circ} \mathrm{C}$. The dried waste powder is called calcine. The calcine is mixed with glass forming chemicals as it falls from the cone section of the spray calciner into a heated receiving canister. The solid calcine/glass former mixture is heated to a temperature of 1000 to $1050^{\circ} \mathrm{C}$ and converted to a vitreous product.

Off-gas from the solidification process consists primarily of atomizing gas, water vapor, $\mathrm{NO}_{x}$ from nitrate decomposition, volatile waste components ( $\mathrm{Hg}, \mathrm{HgO}, \mathrm{HgCl}_{2}, \mathrm{HgI}_{2}$ ) and semivolatile components (cesium and ruthenium). This off-gas is filtered through the spray calciner filters before being decontaminated by successive stages of scrubbing, condensation, physical separation, and filtration in the off-gas cleaning system.

The design features of the SC/ICM are summarized in Table 3.1. The SC/ICM was designed to solidify liquid wastes at a rate of 1 to $4 \mathrm{~L} / \mathrm{h}$, corresponding to a glass production rate of 0.3 to $1.3 \mathrm{~kg} / \mathrm{h}$.

The venturi scrubber located approximately $50 \mathrm{~cm}$ from the spray calciner filter outlet cools and partially condenses water vapor from the off-gas filters and scrubs entrained particulate solid from the gas stream. The venturi scrubber (Figure 3.5) was designed to cool $130 \mathrm{~g}$-moles of noncondensibles gases and $70 \mathrm{~g}$-moles of condensible gases per hour from 350 to $100^{\circ} \mathrm{C}$ using $12 \mathrm{~L} / \mathrm{h}$ of scrub solution. During experimental operations the venturi scrubber cooled the off-gas from approximately 600 to $60^{\circ} \mathrm{C}$ using 20 to $30 \mathrm{~L} / \mathrm{h}$ of scrub solution. The flow rate of scrub solution is measured by a flowmeter and controlled by adjusting the rotational speed of the pump. The off-gas and scrub solution are separated in a cooling tank, where the scrub solution is cooled. Chilled scrub solution is recycled to the venturi scrubber. The venturi scrubber is fabricated from 304-L stainless steel bar stock. The venturi cooling tank is fabricated from 12-in. stainless steel pipe. It is equipped with cooling coils and has an nominal operating capacity of $30 \mathrm{~L}$. The cooling tank is equipped with diplegs and temperature sensing instrumentation to record the weight factor, specific gravity and temperature of the scrub solution. 
TABLE 3.1. Summary of Design Features of the Laboratory Scale Spray Calciner/ In-Can Melter System

Spray Calciner

Spray Chamber Diameter

Spray Chamber Height

Ten-Element Single-Phase Furnace

Total Power

5.05 in. $(12.8 \mathrm{~cm})$

41.5 in. $(105.4 \mathrm{~cm})$

$10.1 \mathrm{~kW}$

Filters (three)

Pall

Inconel 600

Diameter

Length

Surface Area

1.88 in. $(4.8 \mathrm{~cm})$

18 in. $(45.7 \mathrm{~cm})$

Filter Heater

149.9 in. $^{2}\left(966.9 \mathrm{~cm}^{2}\right)$

Six-Element Single-Phase

Total Power

$7.02 \mathrm{~kW}$

$\underline{\text { In-Can Me1ter }}$

Furnace Diameter

Furnace Height

Eight-Element Single-Phase Furnace

Total Power

5.75 in. $(37.1 \mathrm{~cm})$

20.25 in. $(130.6 \mathrm{~cm})$

Canisters

5 in. dia $\times 21$ in. height

\section{System Capacity}

Liquid Waste to Spray Calciner

Glass Production Rates

$8.6 \mathrm{~kW}$

The cyclone separator (see Figure 3.6) was designed for a gas flow rate of $190 \mathrm{~L} / \mathrm{min}\left(6.75 \mathrm{ft}^{3} / \mathrm{min}\right)$ at $350^{\circ} \mathrm{C}$. The dimensions of the cyclone are those recommended by the Stairmand (Koch and Licht 1980) design for a highefficiency cyclone. With recommended dimensions, the cyclone has an $88 \%$ efficiency for removing entrained water droplets and particulate from the gas stream. The cyclone was fabricated from 304-L stainless steel bar stock. A $2 \mathrm{~L}$ glass vacuum flask was used to collect condensates from the cyclone. 


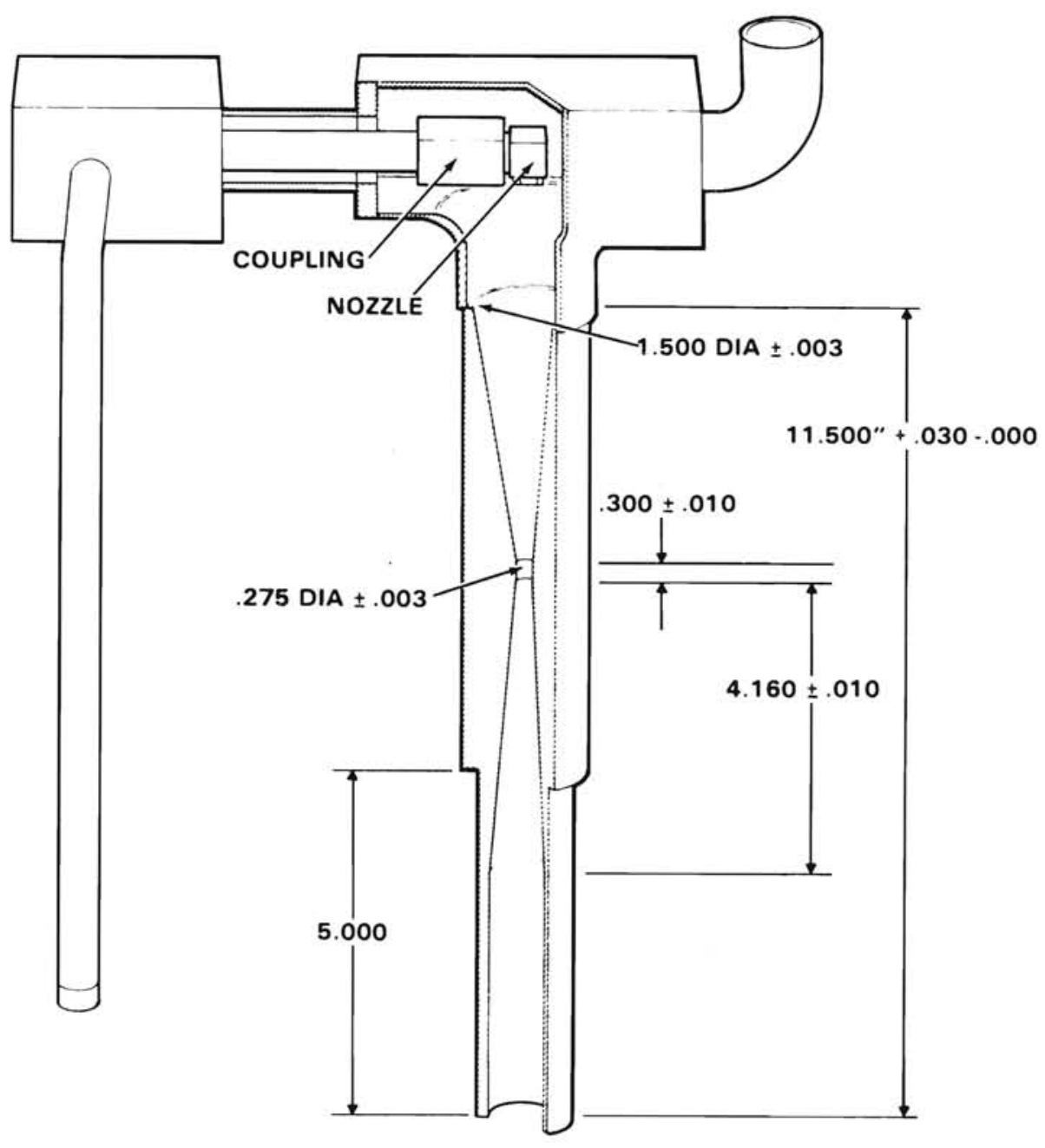

FIGURE 3.5. Schematic of Venturi Scrubber

The downdraft condenser is a commercially available American Standard sheil and tube heat exchanger. The condenser is fabricated from 4-3/16-in. dia 316 stainless steel pipe. The tubes are $1 / 4$ in. dia, having a total surface area of $4.3 \mathrm{ft}^{2}$. Water at a temperature of 8 to $15^{\circ} \mathrm{C}\left(40\right.$ to $\left.60^{\circ} \mathrm{F}\right)$ and a pressure of 30 psig is used as a coolant on the shell side. A $4 \mathrm{~L}$ glass vacuum flask was used to collect condensates from the condenser. During experimental operations the condenser cooled the off-gas stream from approximately 50 to $12^{\circ} \mathrm{C}$.

An off-gas heater was installed in the off-gas system to heat the gaseous effluent above its dew point before passage through a HEPA filter. The heater 


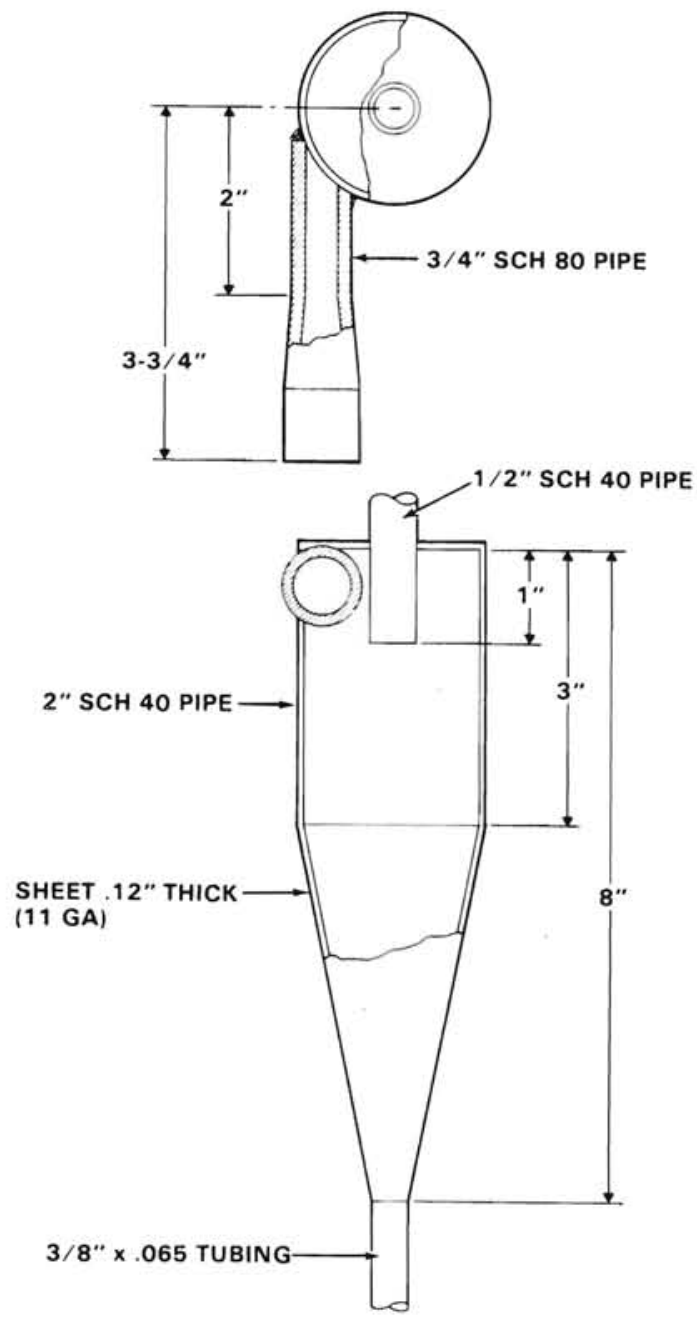

FIGURE 3.6. Schematic of Cyclone Separator

was constructed by mounting, and thermally and electrically insulating Thermcraft ${ }^{\circledR}$ heaters around 2 in. dia, 304-L stainless steel pipe. The power rating on the 120 -volt heaters is 10.4 watts.

The HEPA filters used were manufactured by American Air Filter Company. The filter size was used 8 in. $x 8$ in. $x 5-7 / 8$ in. depth. The filters are rated for a gas flow of $190 \mathrm{~L} / \mathrm{min}\left(50 \mathrm{ft}^{3} / \mathrm{min}\right)$.

@ R Registered trademark Thermcraft Incorporated 


\subsection{EXPERIMENTAL PROCEDURES}

The experimental parameters varied between experiments were; iodide to mercury ratio in the simulated waste, the off-gas temperature at the filter outlet, and the atmospheric conditions within the spray calciner/in-can melter system. All other process variables including the simulated waste composition were kept as consistent as possible for each experiment.

Simulated waste was prepared by precipitation of metallic nitrates and batch washing of the resultant sludge. This feed preparation method, (described in Appendix $A$ ) was used to prepare a simulated waste that represents as closely as possible the physical and chemical properties of actual alkaline Purex waste sludge. The simulated waste for each experimental run was chemically adjusted as required. Routine chemical additions included; sodium chloride, sodium fluoride, and potassium iodide. Particular attention was given to maintaining the iodide to mercury molar ratio at the required values of 0.10 and 0.90 .

The SC/ICM atmospheric conditions were changed by using two different atomizing and service gases. Compressed air was used in the experiments were the initial oxygen content of the off-gas was held at $\sim 20$ vo1\%. An argon/ hydrogen gas mixture of $95 \% \mathrm{Ar} / 5 \% \mathrm{H}_{2}$ was used in those experiments where the oxygen content of the vitrification off gas was controlled to low concentrations (<1 vol\%).

The off-gas outlet temperature was controlled at $300^{\circ} \mathrm{C}$ or $600^{\circ} \mathrm{C}$ by regulating power supplied to heaters located around the spray calciner filter chamber. Temperature sensing elements located in the calciner outlet gas stream were used to detect the gas temperature and provide response information for the power controller.

Prior to each experiment, a canister was weighed and placed inside the in-can melter. The canister was then connected to the spray calciner and a leak check made on the spray calciner/in-can melter system. Sources of detectable off gas inleakage into the system were identified and eliminated. 
The venturi scrub solution was replaced after each experiment with approximately $10 \mathrm{~L}$ of water. Condensates from the cyclone and condenser collection flasks were collected after each experiment and the volume measured.

Solids or metallic mercury accumulated in the venturi scrub solution, the cyclone condensate and in the condenser condensate during all experiments. These solids were separated by vacuum filtration, dried in an oven at 30 to $50^{\circ} \mathrm{C}$ and weighed.

Samples collected during each experiment were initial venturi scrub solution samples, feed samples taken hourly, and off-gas samples. Samples collected after the completion of an experiment were; scrub solution and condensate filtrate samples (venturi, cyclone and condenser), glass samples and various samples of interest such as material deposits in the off-gas piping.

Off-gas samples were collected in stainless steel sample bombs after the off-gas had been passed through a glassware scrub system. This glassware scrub system consisted of a condenser, three gas washing bottles; one filled with water, one empty, and one filled with calcium carbonate, and a $10 \mu \mathrm{m}$ silver particulate filter: The purpose of the gas scrubbing system was to cool and remove water vapor and particulate from the off gas, providing a dry gas sample free of particulate for analysis.

\subsection{SAMPLE ANALYSIS METHODS}

A wide range of chemical analysis methods were used to characterize the samples collected during each experiment. The analyses methods used for each type of sample are summarized in Table 3.2. Analyses of particular interest are those for mercury and iodide. Mercury analyses for the liquid samples and glass samples were performed by flameless atomic absorption spectroscopy. Mercury analysis for solids recovered from the venturi scrub solution were performed using x-ray fluorescence, comparing the response peak areas to a known standard. Iodide analysis were normally performed using neutron activation analysis. The irradiated samples were compared against a standard after corrections for decay were made. Iodide in the feed samples was also determined by x-ray fluorescence. 
TABLE 3.2. Analysis Methods for Samples Collected During Mercury Study

\begin{tabular}{|c|c|c|c|c|c|}
\hline \multirow[b]{2}{*}{ Analysis Method } & \multicolumn{5}{|c|}{ Sample Type } \\
\hline & $\begin{array}{c}\text { Simulated } \\
\text { Alkaline Feed } \\
\text { Slurry (Liquid) } \\
\end{array}$ & $\begin{array}{l}\text { Scrub Solution } \\
\text { and Condensate } \\
\text { Samples (Liquid) } \\
\end{array}$ & $\begin{array}{l}\text { Glass } \\
\text { Samples } \\
\text { (Powder) } \\
\end{array}$ & $\begin{array}{l}\text { Venturi } \\
\text { Solid Samples } \\
\text { (Powder) } \\
\end{array}$ & $\begin{array}{c}\text { Calciner } \\
\text { Off-Gas } \\
\text { (Gas) } \\
\end{array}$ \\
\hline $\begin{array}{l}\text { Induction-Coupled } \\
\text { Plasma }\end{array}$ & $x$ & $x$ & $x$ & & \\
\hline $\begin{array}{l}\text { Flameless Atomic } \\
\text { Absorption }(\mathrm{Hg})\end{array}$ & $x$ & $x$ & $x$ & & \\
\hline Ion Chromatography & $x$ & $x$ & $x$ & $x$ & \\
\hline Mass Spectroscopy & & & & & $x$ \\
\hline $\begin{array}{l}\text { Neutron Activation } \\
\text { Analys is (I) }\end{array}$ & & $x$ & $x$ & $x$ & \\
\hline X-Ray Diffraction & & & & $x$ & \\
\hline $\begin{array}{l}\text { X-Ray Fluorescence } \\
(\mathrm{Hg}, \mathrm{I})\end{array}$ & $x$ & & & $x$ & \\
\hline $\begin{array}{l}\text { Scanning Electron } \\
\text { Microscope, X-Ray } \\
\text { Microprobe }\end{array}$ & & & & $x$ & \\
\hline
\end{tabular}




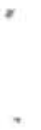

. 


\subsection{EXPERIMENTAL RESULTS}

Twelve experiments were successfully completed during the mercury study project. Eight of these experiments formed the nodes in the $2^{3}$ experimental design. Four of the twelve experiments were duplicated to increase reliability of the experimental data.

\subsection{GENERAL SYSTEM BEHAVIOR}

Some generalizations can be concluded about the behavior of mercury during vitrification of alkaline Purex waste. Essentially all of the mercury was volatized from the vitrification system. Approximately $90 \%$ of this mercury reacts in the gas phase with other chemical components in the system, predominately iodine, chlorine, and oxygen to form a dense particulate. The remaining $10 \%$ of the mercury is recovered as metallic mercury. Essentially all of the mercury can be recovered from the vitrification off gas by scrubbing and condensation. However, accumulation of mercury solids within the off-gas piping prevented quantitative recovery of mercury for material balance purposes.

Essentially all of the mercury fed to the vitrification process is volatized. Mercury was detected in the glass product, however its concentration was less than $5 \times 10^{-4} \mathrm{wt} \%$. The majority of this mercury volatized from the vitrification process was recovered by the venturi scrubber (20 to $50 \%$ ) and lesser quantities were recovered in the cyclone (0.5 to $3 \%$ ) and condenser ( 1 to $5 \%$ ). A large fraction ( 37 to $90 \%$ of $\mathrm{Hg}$ in original waste) of mercury was not recovered in the scrub or condensate solutions. The unrecovered mercury was deposited within the off-gas piping as mercury and mercury compounds formed from reaction with chlorine, iodine, and oxygen. The off-gas leaving the condenser was cooled to a temperature of 7 to $13^{\circ} \mathrm{C}$. The condenser acting as cold trap (mercury vapor pressure $<0.001 \mathrm{~mm} \mathrm{Hg}$ ) is believed to have contained all the mercury within the off-gas system. A summary of the experimental runs is found in Appendix B.

Mercury recovered from the vitrification system off-gas formed either a dense solid or mercury globules. Particulate solid recovered by the venturi and cyclone scrubbers were comprized primarily of mercury halide and oxide 
compounds. Mercury recovered by the condenser was primarily metallic mercury formed by condensation of mercury vapor. These two different forms of mercury indicate that effective mercury removal from the vitrification off gas will require both particulate scrubbing and scrubbing by condensation.

The fate of iodide in the vitrification and off-gas system was strongly influenced by the oxygen content of the system. As shown in Figure 4.1 iodide retention in the glass formed varied from 27 to $55 \%$ when the vitrification system atmosphere contained a small oxygen concentration ( $<1$ vol\%). Iodide retention in the glass was reduced to 3 to $15 \%$ when the oxygen concentration of the vitrification system was approximately $20 \%$. Uncertainties in the experimental data did not allow any conclusions to be drawn from the variation in iodide content in the glass as a function of vitrification system outlet gas temperature or iodide to mercury ratio in the alkaline waste feed. Differences

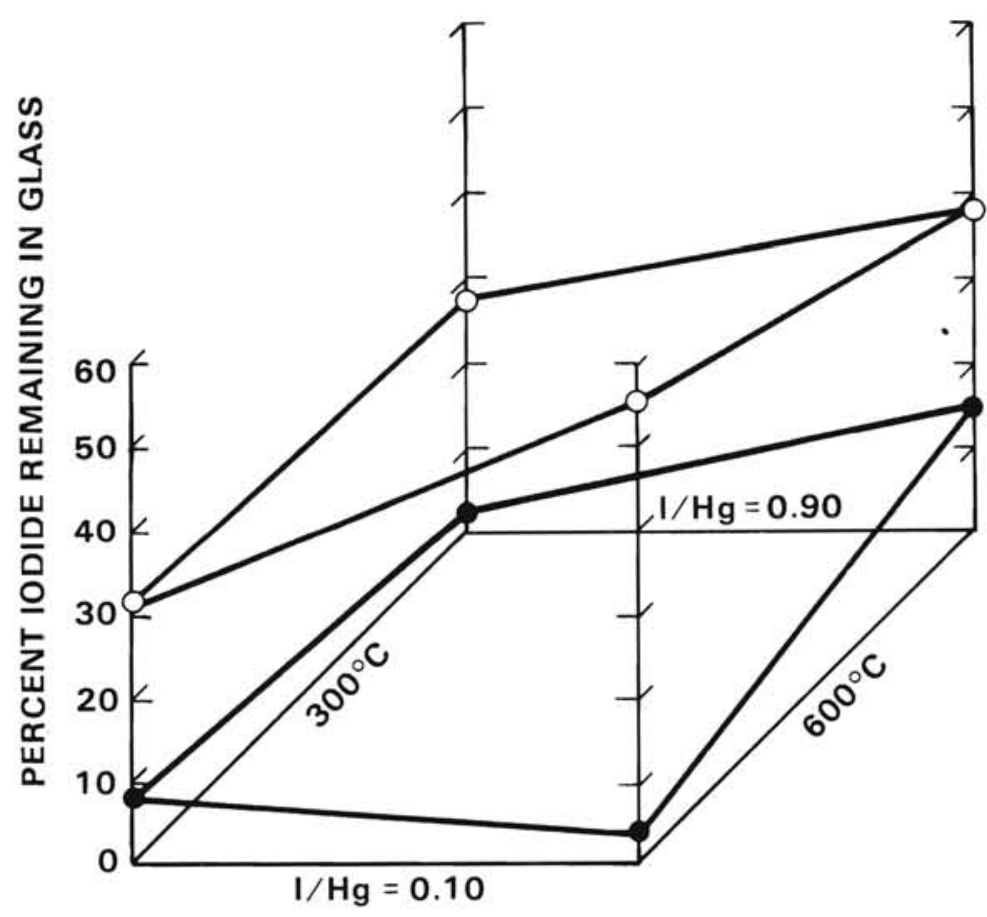

- VITRIFICATION SYSTEM ATMOSPHERE, AIR

O VITRIFICATION SYSTEM ATMOSPHERE, 95\% ARGON, 5\% HYDROGEN

FIGURE 4.1. Percent Iodide Retention in Glass for Experiments Performed in Mercury Study 
in the amount of iodide retained in the glass between the two atmospheric conditions suggests that iodide volatization from the vitrification process is a function of oxygen content in the vitrification off-gas. Iodide and chloride, which exhibits similar behavior, react with oxygen to form volatile iodine and chlorine.

Iodide can react in basic solutions to form iodine which has a low solubility $\left(\sim 10^{-3} \underline{M}\right)$ in the solution (Cotton and Wilkinson 1972). Iodine evolution from the slightly basic waste solution is therefore possible however, this does not explain the significant difference in iodide retention in the vitreous product with change in vitrification system atmosphere.

Once volatile iodine and chlorine are formed they will be removed from the process and potentially react with mercury metal also believed to be formed in the gas phase. Iodide and chloride not converted to volatile iodine or chlorine will remain in the glass as a salt, such as $\mathrm{NaI}$ and $\mathrm{NaCl}$.

Recovery of iodine from the vitrification system off-gas was low. Iodine losses ranged from 30 to $75 \%$ dependent upon the atmospheric conditions as discussed before. It is believed that the majority of the unrecovered iodide is combined with mercury as solid deposits in the off-gas piping. The only significant iodine trapping mechanism is reaction with mercury in the gas phase to form a semivolatile compound (probably $\mathrm{HgI}_{2}$ ) which can be removed from the off-gas by scrubbing. Iodine recovery efficiencies by reaction with mercury ranged from 20 to $50 \%$ based on the collected solids only. Recovery efficiencies were not significantly dependent upon the vitrification system outlet gas temperature. However, the iodine recovery efficiency was found to be dependent upon the iodide to mercury ratio in the simulated waste. Table 4.1 illustrates these results.

Iodide retention in solids recovered from the venturi scrubber tank is significantly reduced at high iodide to mercury ratios $(0.90)$ in the simulated waste. The iodide retention in the glass did not vary signficantly with iodide to mercury ratio in the waste (refer to Figure 4.1 ). This suggests that there is competition between iodine and other compounds for reaction with mercury. 
TABLE 4.1. Recovery of Iodide by Venturi Scrubber

Oxygen Concentration

in Vitrification

System Atmosphere

(Vol\%)

น20

Molar Ratio
I/Hg in
Simulated Wast

Percent

$\sim 20$

0.1

Recovery

$\sim 0$

0.9

0.1

0.9

in Venturi

39 to 51

21 to 28

32 to 38

5 to 6

These other chemical species are probably oxygen and chlorine. The lack of dependence of iodide recovery on the vitrification system temperature is important, because this confirms that the reaction kinetics between mercury and iodine are fast.

\subsection{CHARACTERISTICS OF MERCURY SOLIDS}

The majority of the mercury recovered from the vitrification off gas condensed to form a dense, finely divided solid. Mercury solids were formed in all experiments conducted, however the chemical composition of the solids varied between each experiment. Table 4.2 summarizes for each experiment the process conditions and the physical and chemical characteristics of the mercury solids recovered from the venturi scrub solution. Flouride was not detected in the mercury solids. The physical characteristics of the mercury solids were identified from x-ray diffraction, scanning electron microscopy, and x-ray microprobe analysis. The mercury concentration in the solids was determined by $x$-ray fluorescence, the iodide concentration by neutron activation analys is and the chloride concentration by ion chromatography. Unidentified material in the mercury solids is thought to be a comprised of oxygen and water.

Mercury solids were also recovered from the cyclone condensate. The quantity of these solids was small $(<1 \mathrm{~g})$, such that chemical analysis of these solids was not practical. The cyclone solids appeared to be very similar to the venturi solids in physical appearance. It was assumed the cyclone solids 
TABLE 4.2. Characteristics of Mercury Solids Recovered from Venturi Scrub Tank

\begin{tabular}{|c|c|c|c|}
\hline $\begin{array}{c}\text { Run } \\
\text { Number }\end{array}$ & $\begin{array}{l}\text { Iodide to } \\
\text { Mercury } \\
\text { Molar } \\
\text { Ratio }\end{array}$ & $\begin{array}{l}\text { Outlet off } \\
\text { Gas Tempera- } \\
\left.\text { ture ( }{ }^{\circ} \mathrm{C}\right)\end{array}$ & \begin{tabular}{l}
\multicolumn{1}{c}{ Oxygen } \\
Concentration \\
Vitrification \\
Off Gas (Vol\%)
\end{tabular} \\
\hline 01 & 0.9 & 300 & $20(h)$ \\
\hline
\end{tabular}

\begin{tabular}{l}
\multicolumn{1}{c}{$\begin{array}{c}\text { Mercury Solids } \\
\text { Characteristics }\end{array}$} \\
\hline XRD(a); Strong HgI line, \\
weak HgCL line, est imate \\
$80 \% \mathrm{HgI}, 20 \% \mathrm{HgCl}$, amor- \\
phous material present \\
MP(b); Very small Hg drop- \\
lets present. Comprised of \\
irregular solids character- \\
istics of HgI. Discrete \\
particles of HgI and $\mathrm{HgCl}$ \\
present.
\end{tabular}

Composition of Mercury Solids(g) (wt\%)

$\mathrm{Hg} \quad 64.2$

I 26.3

C1 2.5

Unidentified 7

02

$\begin{array}{lll}0.1 & 300 & 20\end{array}$

XRD; $\mathrm{HgI}, \mathrm{HgCl}$ weak to moderate approximately equal amounts

MP; Platlet material present ident ified as $\mathrm{HgCL}$, amorphous $\mathrm{HgI}$ present, approximately equal amounts of $\mathrm{HgI}$ and $\mathrm{HgCl}$

XRD, strong $\mathrm{HgI}$, weak to moderate $\mathrm{HgCl}$, estimate $70 \%$ $\mathrm{HgI}, 30 \% \mathrm{HgCl}$ more crystalline character than 01

$\begin{array}{lr}\mathrm{Hg} & 73.8 \\ \mathrm{I} & 14.1 \\ \mathrm{Cl} & 2.2 \\ \text { Unidentified } & 9.9\end{array}$

MP; More amorphous character than 01 no clear differentiation between individual particles

XRD; strong $\mathrm{HgI}$, weak to moderate $\mathrm{HgCl}$ similar to Experiment No. 3 except both patterns weaker less $\mathrm{HgI}$ more $\mathrm{HgCL}$ crystals than 01

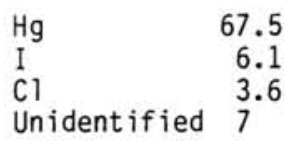

MP; $\mathrm{HgCL}$ more prevalent than $\mathrm{HgI}$ solid is crystalline, small crystals cubic in shape $\mathrm{Fe}, \mathrm{Cr}$ present in sample

XRD; Very weak $\mathrm{HgI}$, no $\mathrm{HgCL}$ amorphous halo on spectrograph indicates no crystalline material present

MP; Spectrograph indicates no $\mathrm{HgCl}$, very weak $\mathrm{HgI}$. $V$ isually many small mercury beads present, material amorphous

XRD; Weaker HgI signal than Exper iment No. 5, mostly uncrystallized material

MP; No $\mathrm{HgCL}$ observed, small amount of $\mathrm{HgI}$; visually amorphous material with many small mercury beads

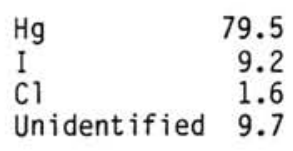

$\begin{array}{lr}\mathrm{Hg} & 86.4 \\ \mathrm{I} & 3.0 \\ \mathrm{Cl} & 0.2 \\ \text { Unident if ied } & 10.4\end{array}$


TABLE 4.2. (contd)

\begin{tabular}{|c|c|c|c|c|c|c|}
\hline $\begin{array}{c}\begin{array}{c}\text { Run } \\
\text { Number }\end{array} \\
\end{array}$ & $\begin{array}{l}\text { Iodide to } \\
\text { Mercury } \\
\text { Molar } \\
\text { Ratio } \\
\end{array}$ & $\begin{array}{l}\text { Outlet off } \\
\text { Gas Tempera- } \\
\text { ture (OC) } \\
\end{array}$ & \begin{tabular}{l}
\multicolumn{1}{c}{ Oxygen } \\
Concentration \\
Vitrification \\
Off Gas (Vol\%) \\
\end{tabular} & $\begin{array}{l}\text { Mercury Solids } \\
\text { Characteristics }\end{array}$ & \multicolumn{2}{|c|}{$\begin{array}{c}\text { Composition of } \\
\text { Mercury Solids } \\
\text { (wt\%) }\end{array}$} \\
\hline 07 & 0.9 & 300 & 0 & $\begin{array}{l}\text { XRD; Moderate HgI, no } \mathrm{HgCL} \text {, } \\
\text { HgI intensity like } 05 \\
\text { MP; HgI, HgCL present, dis- } \\
\text { crete particles observable, } \\
\text { a lot of crystalline } \mathrm{HgCL} \\
\text { present, amorphous } \mathrm{HgI} \text { pre- } \\
\text { sent }\end{array}$ & $\begin{array}{l}\mathrm{Hg} \\
\mathrm{I} \\
\mathrm{Cl} \\
\text { Unident ified }\end{array}$ & $\begin{array}{r}81.6 \\
8.8 \\
0.3 \\
9.3\end{array}$ \\
\hline 08 & 0.90 & 600 & 0 & $\begin{array}{l}\text { XRD; Very strong } \mathrm{HgI} \text {, no } \\
\mathrm{HgCL} \text { present amorphous } \\
\text { material present } \\
\text { MP; Solid very amorphous } \\
\text { in character comprised of } \\
\mathrm{HgI} \text {, no HgCL present }\end{array}$ & $\begin{array}{l}\mathrm{Hg} \\
\mathrm{I} \\
\mathrm{Cl} \\
\text { Unidentified }\end{array}$ & $\begin{array}{r}79.8 \\
10.6 \\
0.06 \\
9.54\end{array}$ \\
\hline $09(c)$ & 0.1 & 300 & 20 & $\begin{array}{l}\text { MP; Solid composed of largely } \\
\mathrm{HgI} \text { with Some } \mathrm{HgCl} \text {. Solid } \\
\text { amorphous in form }\end{array}$ & $\begin{array}{l}\mathrm{Hg} \\
\mathrm{I} \\
\mathrm{Cl} \\
\text { Unidentified }\end{array}$ & $\begin{array}{r}71.1 \\
17.6 \\
0.7 \\
10.6\end{array}$ \\
\hline $10(d)$ & 0.9 & 600 & 20 & $\begin{array}{l}\text { MP; Solid comprised mostly of } \\
\text { HgI with more } \mathrm{HgCl} \text { than } 09 . \\
\text { Crystalline solids present } \\
\text { characteristic of } \mathrm{HgCl}\end{array}$ & $\begin{array}{l}\mathrm{Hg} \\
\mathrm{I} \\
\mathrm{Cl} \\
\text { Unidentified }\end{array}$ & $\begin{array}{r}61.5 \\
15.1 \\
2.0 \\
21.4\end{array}$ \\
\hline $11(\mathrm{e})$ & 0.9 & 300 & 0 & $\begin{array}{l}\text { MP; Solid amorphous in struc- } \\
\text { ture, some } \mathrm{Hg} \text { droplets present } \\
\text { strong } \mathrm{HgI} \text { response from solid } \\
\text { sample }\end{array}$ & $\begin{array}{l}\mathrm{Hg} \\
\mathrm{I} \\
\mathrm{Cl} \\
\text { Unidentified }\end{array}$ & $\begin{array}{r}74.2 \\
19.0 \\
0.2 \\
6.6\end{array}$ \\
\hline $12(f)$ & 0.1 & 600 & 0 & $\begin{array}{l}\text { MP; Solid has some crystalline } \\
\text { characteristics some mercury } \\
\text { droplets present }\end{array}$ & $\begin{array}{l}\mathrm{Hg} \\
\mathrm{I} \\
\mathrm{Cl} \\
\text { Unidentified }\end{array}$ & $\begin{array}{r}79.0 \\
11.5 \\
0.4 \\
9.1\end{array}$ \\
\hline
\end{tabular}

(a) XRD; Information obtained from $x$-ray diffraction.

(b) MP; Information obtained from Scanning Electron Microscope and Microprobe $X$-Ray Analysis.

(c) Repeat of experiment no. 2.

(d) Repeat of experiment no. 3.

(e) Repeat of experiment no. 7 .

(f) Repeat of experiment no. 5 .

(g) Analysis methods: $\mathrm{Hg}$, x-ray fluorescence; I, neutron activation analysis; $\mathrm{Cl}$ ion chromatography.

(h) Typical gas composition leaving vitrification system; $\mathrm{CO}_{2} 2.07 \%, \mathrm{Ar}$ $0.89 \%, 0_{2} 22.1 \%, \mathrm{~N}_{2} 74.4 \%$, CO $0.4 \%$, $\mathrm{NO}_{\mathrm{x}} 0.13 \%$.

(i) Typical gas composition leaving vitrification system; $\mathrm{CO}_{2} 0.67 \%, \mathrm{Ar}$ $72.4 \%, \mathrm{O}_{2} 0.01 \%, \mathrm{~N}_{2} 26.3 \%, \mathrm{H}_{2} 0.13 \%, \mathrm{~N}_{2} \mathrm{O} 0.47 \%$. 
had the same chemical composition as the venturi solids for material balance purposes. Metallic mercury was the primary mercury species recovered from the condenser condensate.

The chemical composition of the mercury solids for eight different experiments conducted is shown graphically in Figure 4.2 for mercury, in Figure 4.3 for iodide, and in Figure 4.4 for chloride. The axes, iodide to mercury molar ratio in the simulated waste and off-gas outlet temperature are approximate, based upon average values.

There are significant differences in the chemical composition of the mercury solids which are related the process operating variables; the vitrification system atmosphere, the outlet gas temperature, and the iodide to mercury molar ratio in the waste. As shown in Figure 4.2 the mercury concentration of the mercury solids was 75 to $85 \mathrm{wt} \%$ when there is essentially no oxygen present in the vitrification off-gas. The mercury concentration was reduced to 65 to $75 \mathrm{wt} \%$ when atmospheric concentrations ( $20 \mathrm{v}$ v $1 \%$ ) of oxygen are present in the vitrification off gas. The difference is due to the low oxygen concentration present in the vitrification off-gas which retains a greater fraction of iodide and chloride in the glass, being unavailable to react with mercury in the gas phase. It cannot be deduced from the chemical composition of solids whether or not there is less mercury as oxide in the solids formed, in experiments performed with very little oxygen present, as compared to the experiments performed with $\sim 20$ v01\% oxygen present. The key to drawing this conclusion is in characterization of the unidentified solid component of the mercury solids. It is believed that the unidentified chemical species are principally oxygen and water.

The iodide and chloride concentrations in the mercury solids are greater in the experiments conducted with atmospheric concentrations of oxygen present in the vitrification system. This is the result of two phenomena. First, the iodide and chloride are converted to volatile iodine and chlorine to a greater extent when large quantities of oxygen are present. Secondly, the higher relative concentrations of iodine and chlorine in the gas phase react with mercury to produce higher concentrations of the mercury halide compounds. 


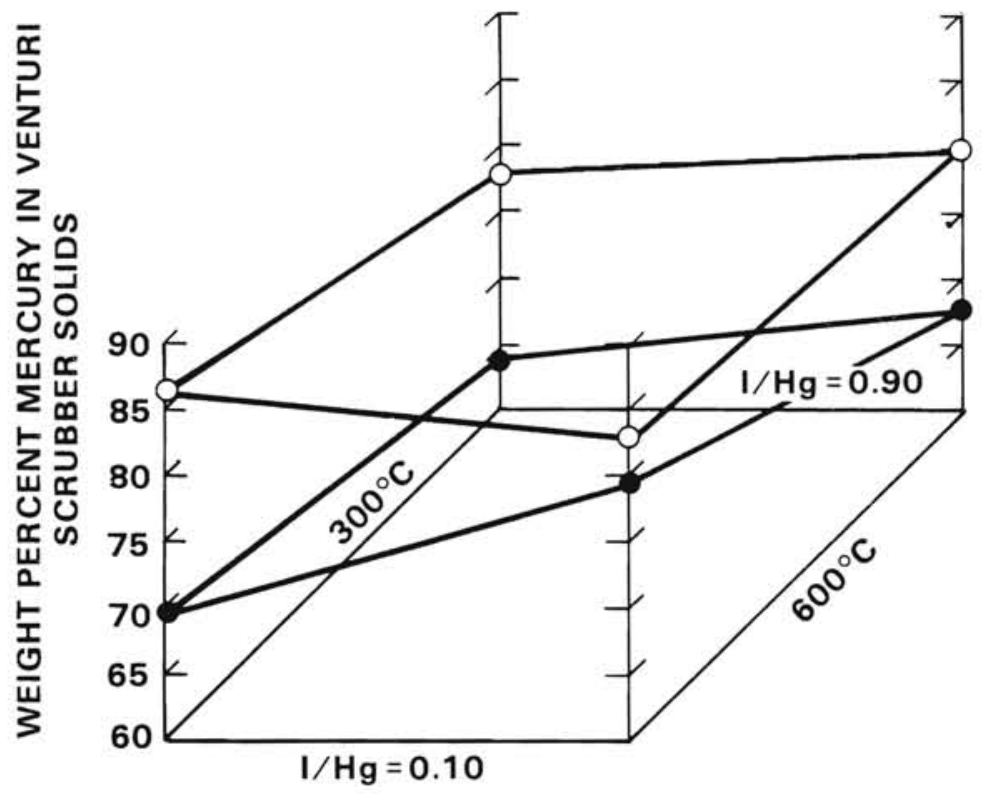

- VITRIFICATION SYSTEM ATMOSPHERE, AIR

O VITRIFICATION SYSTEM ATMOSPHERE, 95\% ARGON, $5 \%$ HYDROGEN

FIGURE 4.2. Mercury Composition of Off-Gas Solids Collected During Experiments

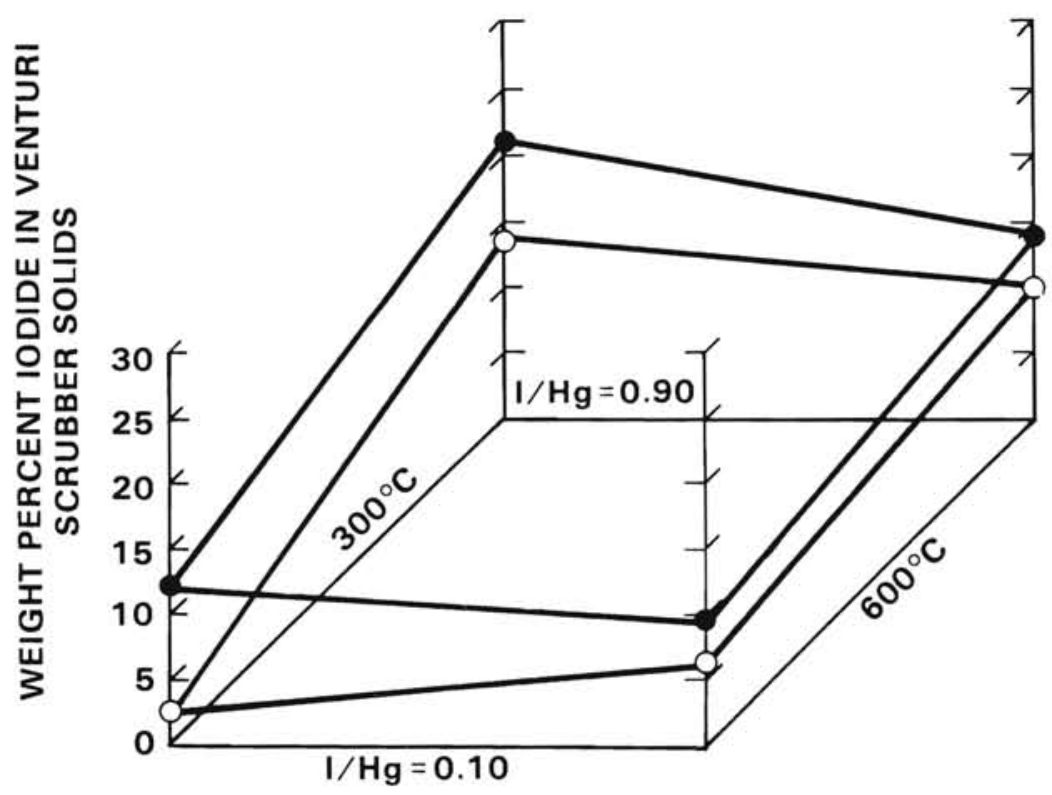

VITRIFICATION SYSTEM ATMOSPHERE AIR

O VITRIFICATION SYSTEM ATMOSPHERE, 95\% ARGON 5\% HYDROGEN

FIGURE 4.3. Iodide Composition of Off-Gas Solids Collected During Mercury Study Experiments 


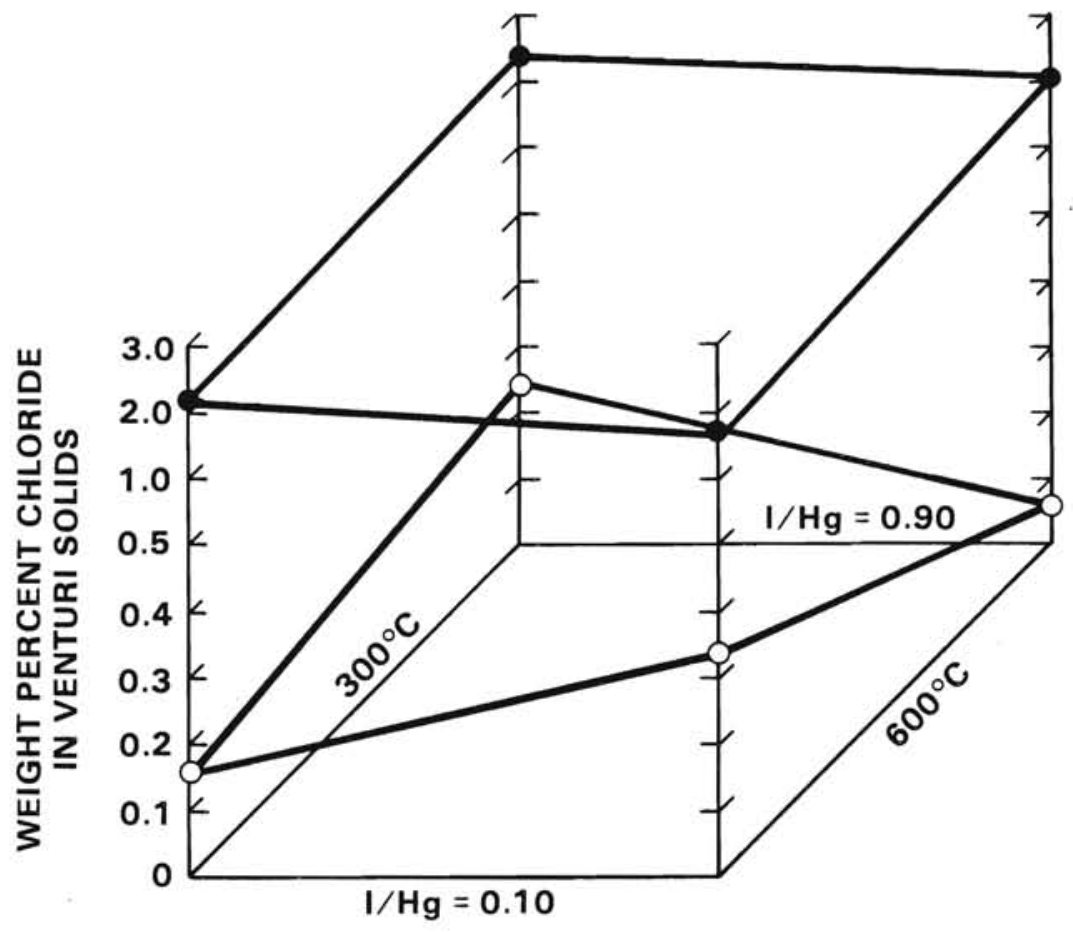

- VITRIFICATION SYSTEM ATMOSPHERE AIR

O VITRIFICATION SYSTEM ATMOSPHERE, 95\% ARGON, 5\% HYDROGEN

FIGURE 4.4. Chloride Composition of Off-Gas Solids Collected During Mercury Study Experiments

Recall that the mercury halides are thermodynamically preferred over the mercury oxides as reaction products in the gas phase.

The mercury solids recovered from the scrub solution were identified as $\mathrm{HgI}$ (or $\mathrm{Hg}_{2} \mathrm{I}_{2}$ ) and $\mathrm{HgCl}$ (or $\mathrm{Hg}_{2} \mathrm{Cl}_{2}$ ) by $x$-ray diffraction analyses. These two compounds are relatively insoluble, and are in equilibrium with; $\mathrm{Hg}, \mathrm{HgI}_{2}$ and $\mathrm{Hg}, \mathrm{HgCl}_{2}$, respectively. The equilibrium constants for these reactions are summarized below. (Lindsay 1979)

$$
\begin{aligned}
& \frac{[\mathrm{Hg}]\left[\mathrm{HgI}_{2}\right]}{\left[\mathrm{Hg}_{2} \mathrm{Cl}_{2}\right]}=2.2 \times 10^{-3} \\
& \frac{[\mathrm{Hg}][\mathrm{HgCl}]}{\left[\mathrm{Hg}_{2} \mathrm{Cl}{ }_{2}\right]}=8.3 \times 10^{-6}
\end{aligned}
$$


The reaction equilibria between; $\mathrm{Hg}, \mathrm{Hg}_{2} \mathrm{I}_{2}$ and $\mathrm{HgI}_{2}$ or $\mathrm{Hg}, \mathrm{Hg}_{2} \mathrm{Cl}_{2}$ and $\mathrm{HgCl}_{2}$ is a disproportionation reaction. The mercuric form $\left(\mathrm{Hg}^{+2}\right)$ is readily soluble by complexation with excess chloride or iodide. However, because mercury metal is essentially insoluble in water $\left(10^{-7} \mathrm{M}\right.$ @ $\left.25^{\circ} \mathrm{C}\right)$ the disproportionation can occur only to a very limited extent, explaining the small equilibrium constants. It is thought that $\mathrm{HgI}_{2}$ and $\mathrm{HgCl}_{2}$ are the chemical species formed in the gas phase. Upon quenching the off-gas by the scrub solution or condenser, $\mathrm{HgI}_{2}$ disproportionates to $\mathrm{Hg}_{2} \mathrm{I}_{2}$. A similar mechanism is postulated for $\mathrm{HgCl}_{2}$ and $\mathrm{Hg}_{2} \mathrm{Cl}_{2}$. The $\mathrm{HgI}_{2}$ compound is more stable than $\mathrm{Hg}_{2} \mathrm{I}_{2}$ in the gas phase, the opposite is true in the liquid or condensed phase.

Photographs of the mercury solids recovered from the venturi scrub solution for five of the twelve experiments are shown in Photos 4.1 through 4.5. These photographs were taken with a scanning electron microscope (SEM). Each photograph records characteristics of the mercury solids coincident with the experimental conditions.

Photograph 4.1 (from Experiment No. 1) displays the difference in physical structure between the $\mathrm{HgCl}$ and $\mathrm{HgI}$ particles. The $\mathrm{HgCl}$ compound is comprised of particles which are crystalline in character (Point 1). The HgI compound is comprised of particles which are largely amorphous in character (Point 2). The microprobe (x-ray) micrographs of each of the two particulate types are shown in Figure 4.5 and 4.6 , respectively. No metallic mercury was found in the sample. The reason for this is that mercury has completely reacted with the halogens (chloride and iodide) and oxygen present in the system. Mercury is the limiting reactant in this system. HgI comprises approximately $65 \%$ of the sample and $\mathrm{HgCl}$ comprises approximately $22 \%$ of the solid sample.

Photograph 4.2 (from Experiment No. 4) also displays the difference in character between $\mathrm{HgI}$ and $\mathrm{HgCl}$. This venturi solids sample is comprised of a relatively large quantity of $\mathrm{HgCl}$ when compared to $\mathrm{HgI}$ as indicated by the predominance of cubic crystalline particles present. An x-ray micrograph of the solid is shown in Figure 4.7. The mercury levels in the solid are high, suggesting that mercury oxide may also be present in the sample. 0xygen 


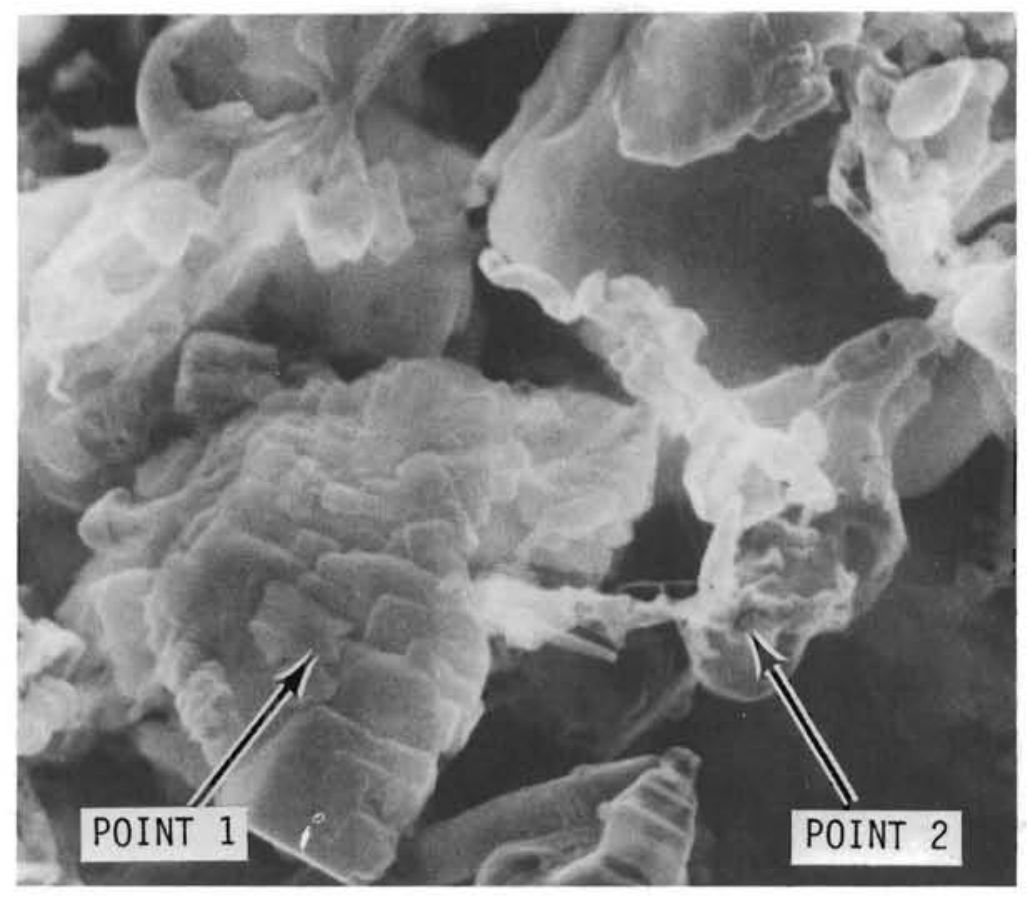

PHОTO 4.1. Photograph of Mercury Solids Collected From Venturi Solution, Experiment No. 1 Showing $\mathrm{HgCl}$ and $\mathrm{HgI}$ particulate $(10,000 \mathrm{X})$

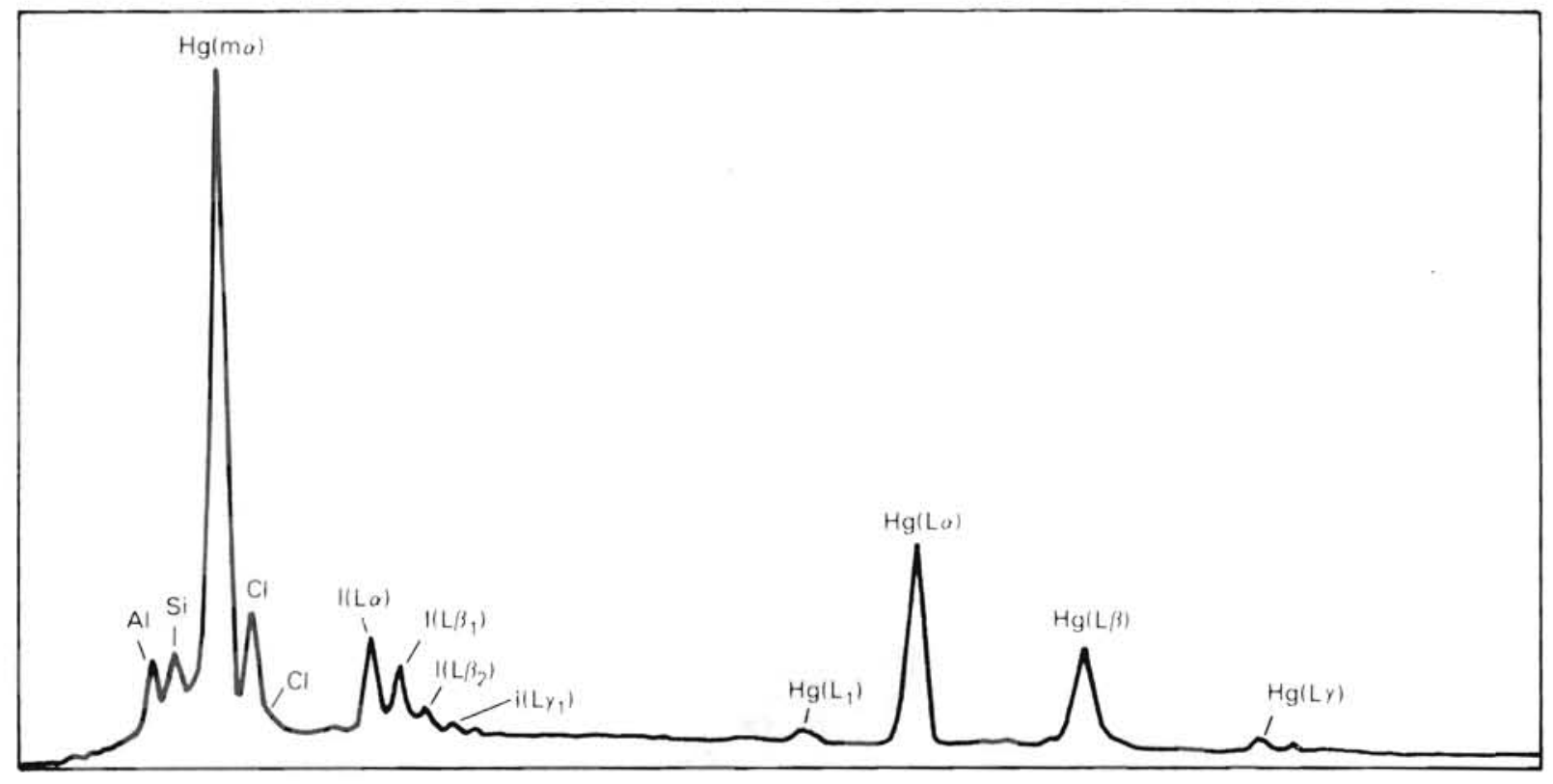

FIGURE 4.5. X-Ray Micrograph of Venturi Solid Sample Feature (Point Number 1) from Experiment No. 1 


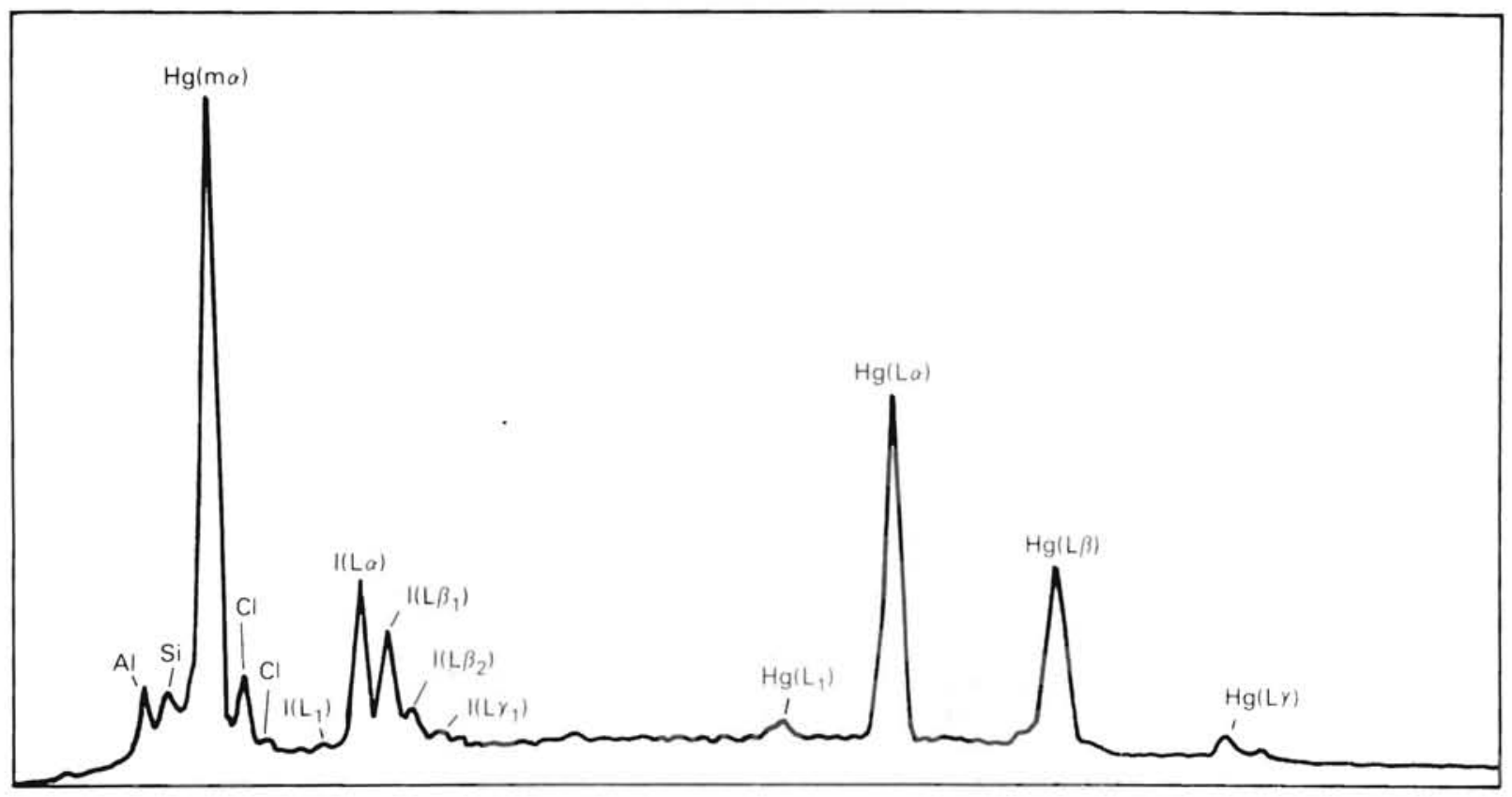

FIGURE 4.6. X-Ray Micrograph of Venturi Solid Sample Feature (Point Number 2) from Experiment No. 1

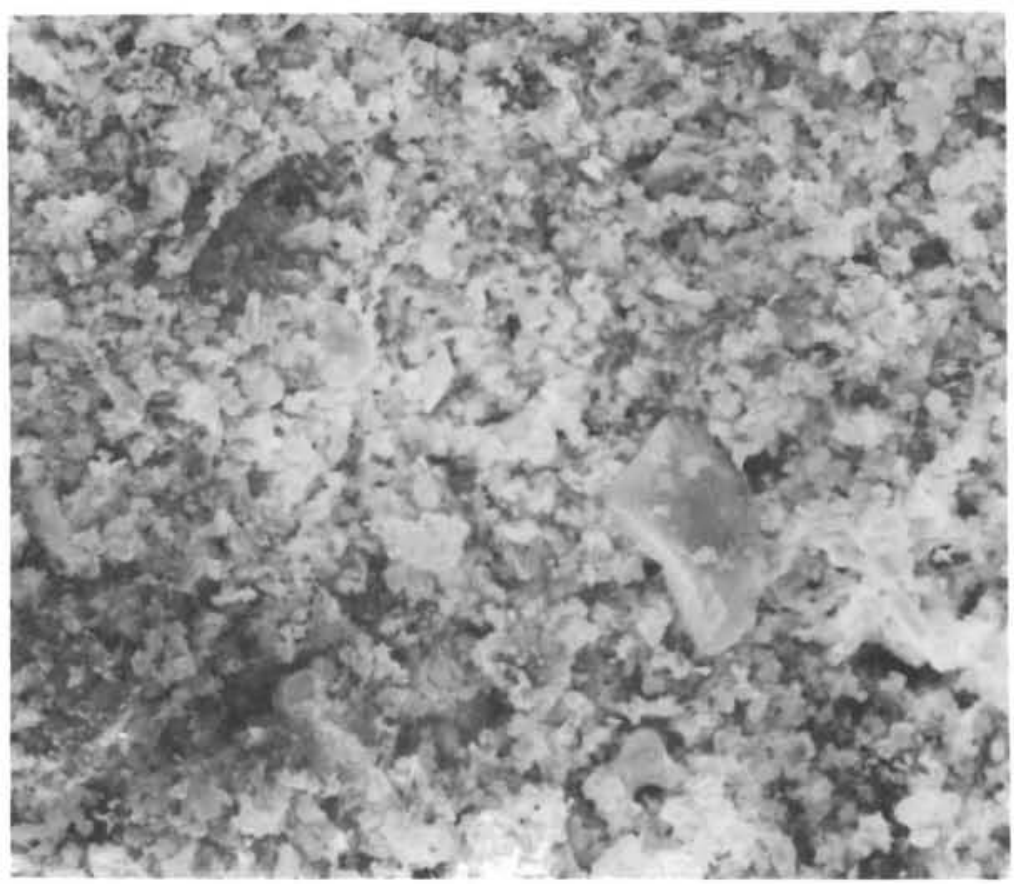

PHOTO 4.2. Photograph of Mercury Solids Collected From Venturi Solution, Experiment No. 4 Showing Crystalline $\mathrm{HgCl}(3,000 \mathrm{X})$ 


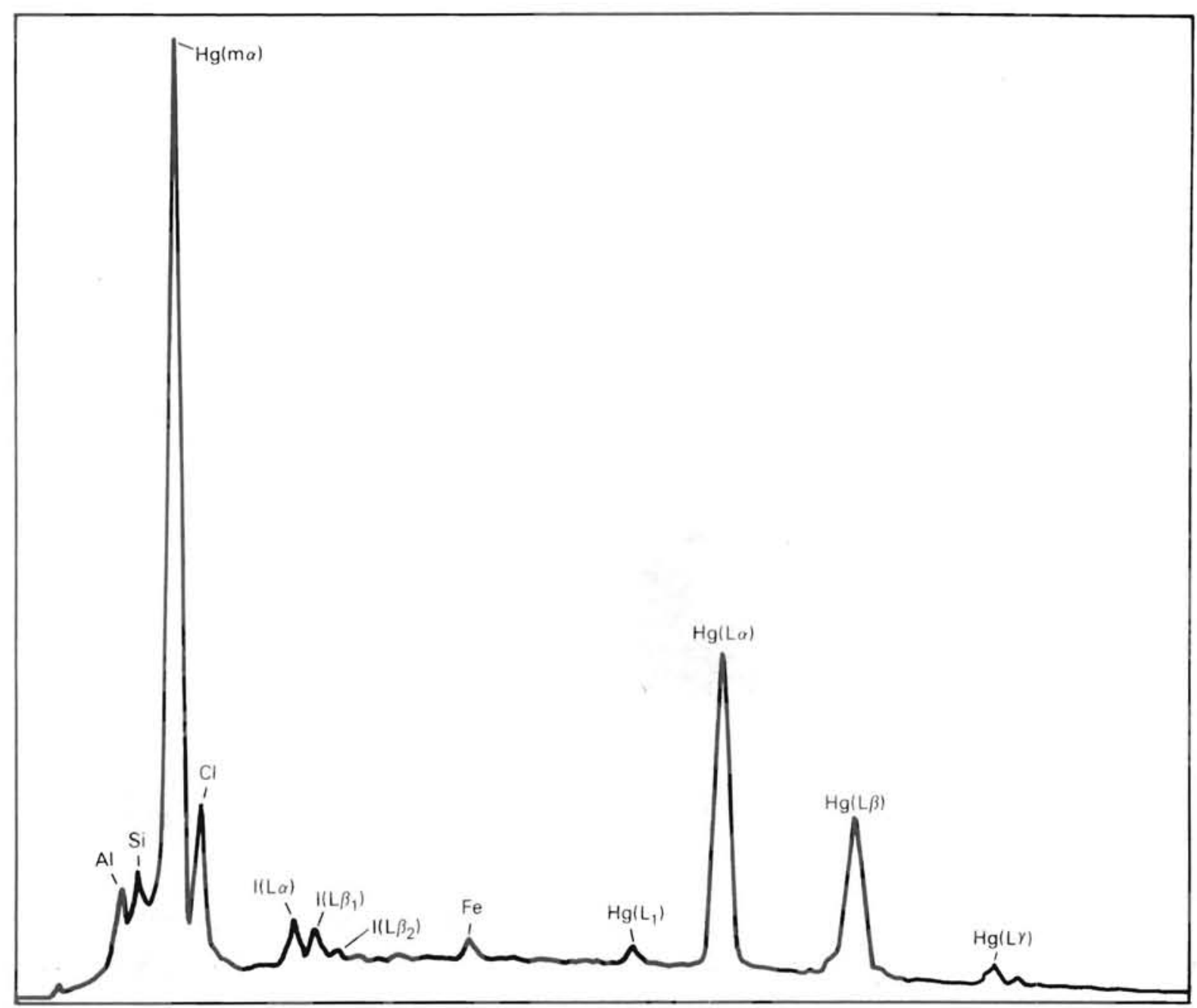

FIGURE 4.7. X-Ray Micrograph of Venturi Solid Sample General Area Scan from Experiment №. 4

(molecular weight 16) cannot not be detected by the $x$-ray microprobe used. The solid sample is comprised of approximately $11 \% \mathrm{HgCl}, 18 \% \mathrm{HgI}$ and the remaining fraction presumed to be $\mathrm{HgO}(71 \%)$.

Photograph 4.3 is of the venturi solids sample recovered from an experiment in which the vitrification atmosphere contained essentially no oxygen, and the molar ratio of total halogen present to total mercury was low (Experiment No. 5). This sample shows that metallic mercury as round beads can be formed. The size of the mercury beads is 1 to $2 \mu \mathrm{m}$. The amorphous material is the 


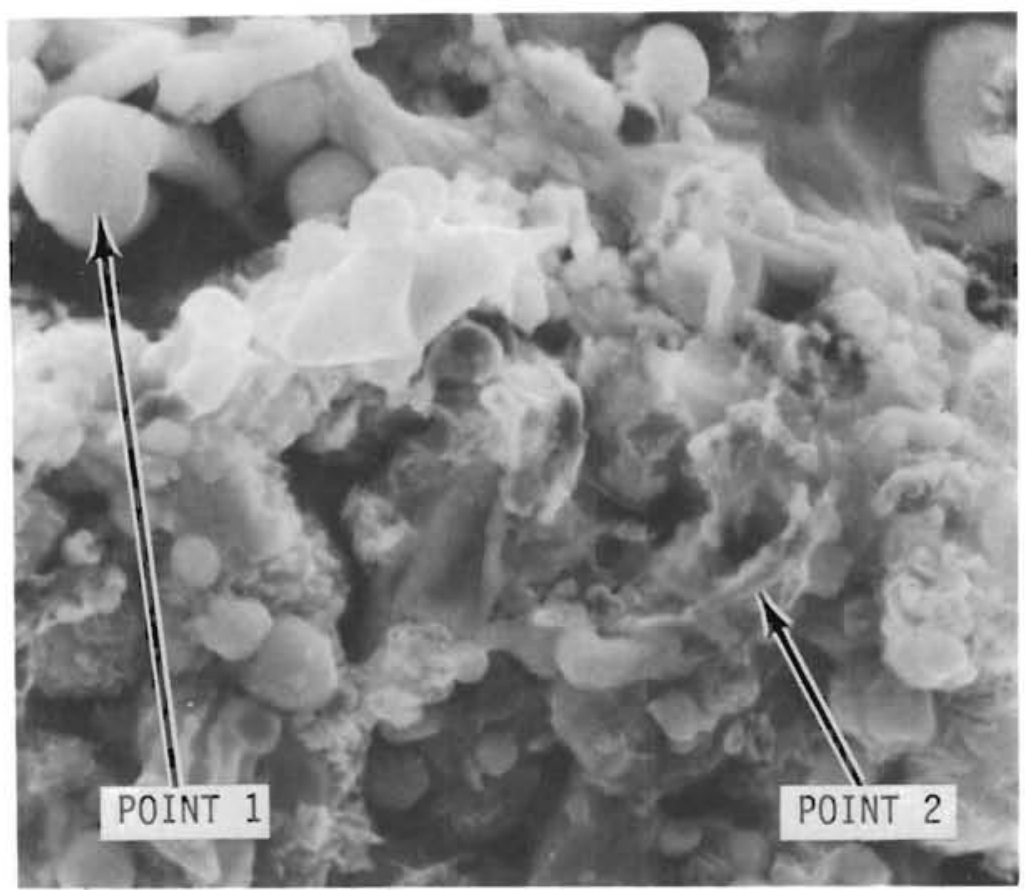

PHOTO 4.3. Photograph of Mercury Solids Collected From Venturi Solution, Experiment No. 5 Showing Mercury Metal and HgI (10,000X)

background is believed to be comprised primarily of mercury oxide $(\mathrm{Hg} 0)$ and mercury iodide $(\mathrm{HgI})$. Figure 4.8 and 4.9 are $x$-ray micrographs of some features of the solid. These micrographs indicate that the sample is comprised primarily of mercury and $\mathrm{HgI}$. The percent of $\mathrm{HgI}$ in the sample is approximately $53 \%$, and the $\mathrm{HgCl}$ concentration approximately $2 \%$.

Photograph 4.4 displays the difference in physical structure between $\mathrm{HgCl}$ and $\mathrm{HgI}$. These solids were recovered from an experiment in which essentially no oxygen was present in the vitrification off gas (Experiment No. 7). The mercury iodide indicated by Point 1 is a structure having an amorphous form. The mercury chloride particle is more geometric in shape. No metallic mercury was found in this sample even though the atmospheric conditions contained essentially little or no oxygen. This may be because the mercury in the sample has evaporated in the SEM. The solid sample is comprised of approximately $17 \%$ $\mathrm{HgI}, 2 \% \mathrm{HgCl}$ and the remainder mercury metal or mercury oxide. Figures 4.10 and 4.11 are x-ray micrographs of the same solid features of this sample. 


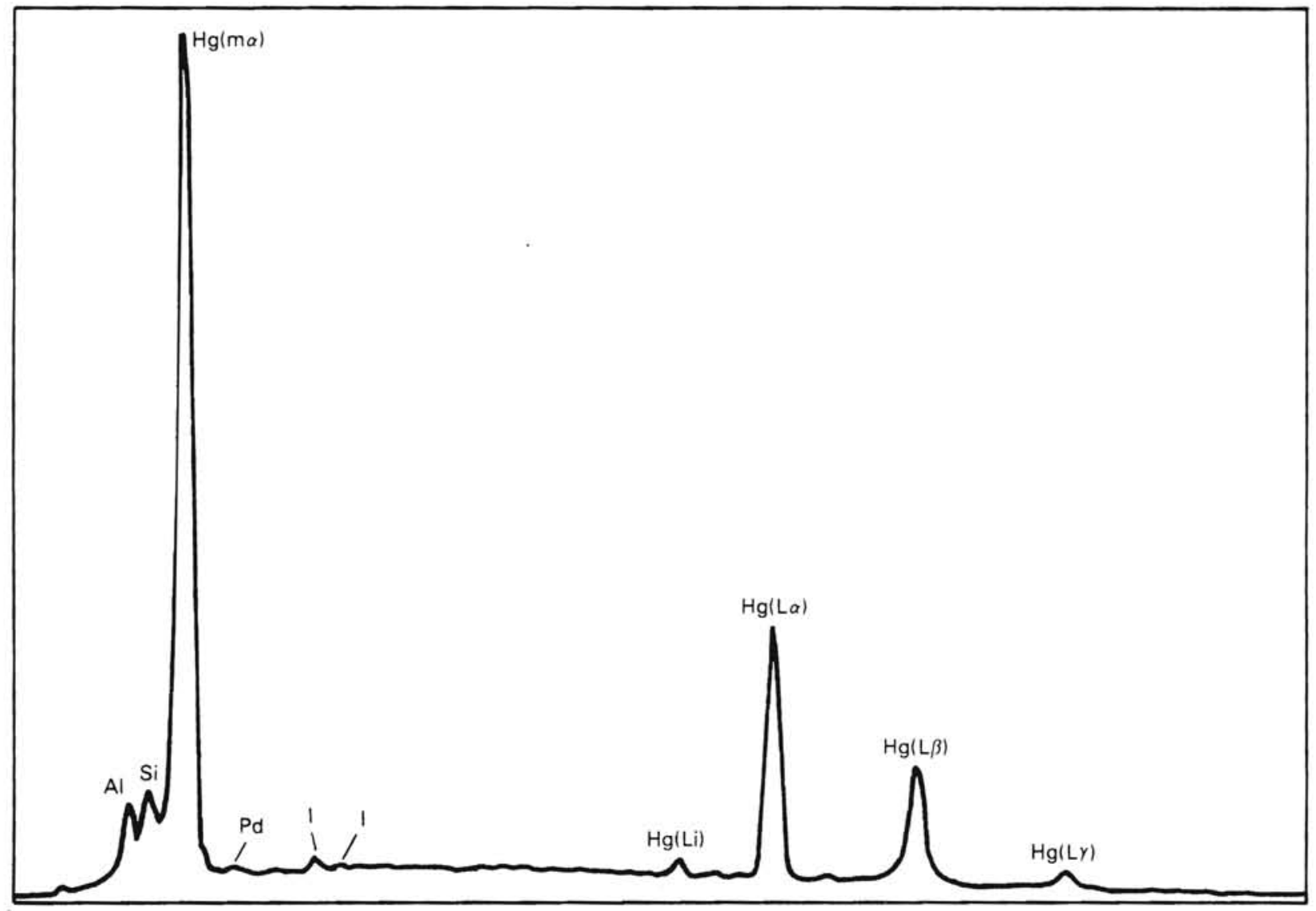

FIGURE 4.8. X-Ray Micrograph of Venturi Solid Sample Amorphous Feature (Point Number 1) from Experiment No. 5

Photograph 4.5 shows the venturi solids recovered from an experiment in which little or no oxygen was present, the iodine to mercury ratio was 0.90 , and the outlet off-gas temperature was $600^{\circ} \mathrm{C}$. The $x$-ray micrograph (Figure 4.12) indicates that the sample is comprised primarily of $\mathrm{HgI}$ and $\mathrm{Hg}$. The chemical composition of this sample is approximately $23 \% \mathrm{HgI}, 3 \% \mathrm{HgCl}$ and the remainder $\mathrm{HgO}$ or $\mathrm{Hg}$ metal. The amorphous character of the solid sample is due to the relatively high $\mathrm{HgI}$ concentration and the large yet unidentified concentration of $\mathrm{HgO}$ and $\mathrm{Hg}$ metal.

\subsection{DISCUSSION OF EXPERIMENTAL RESULTS}

As shown, the chemical behavior of mercury and iodine in the vitrification system is dependent upon the three process variables evaluated ( $\mathrm{I} / \mathrm{Hg}$ ratio in 


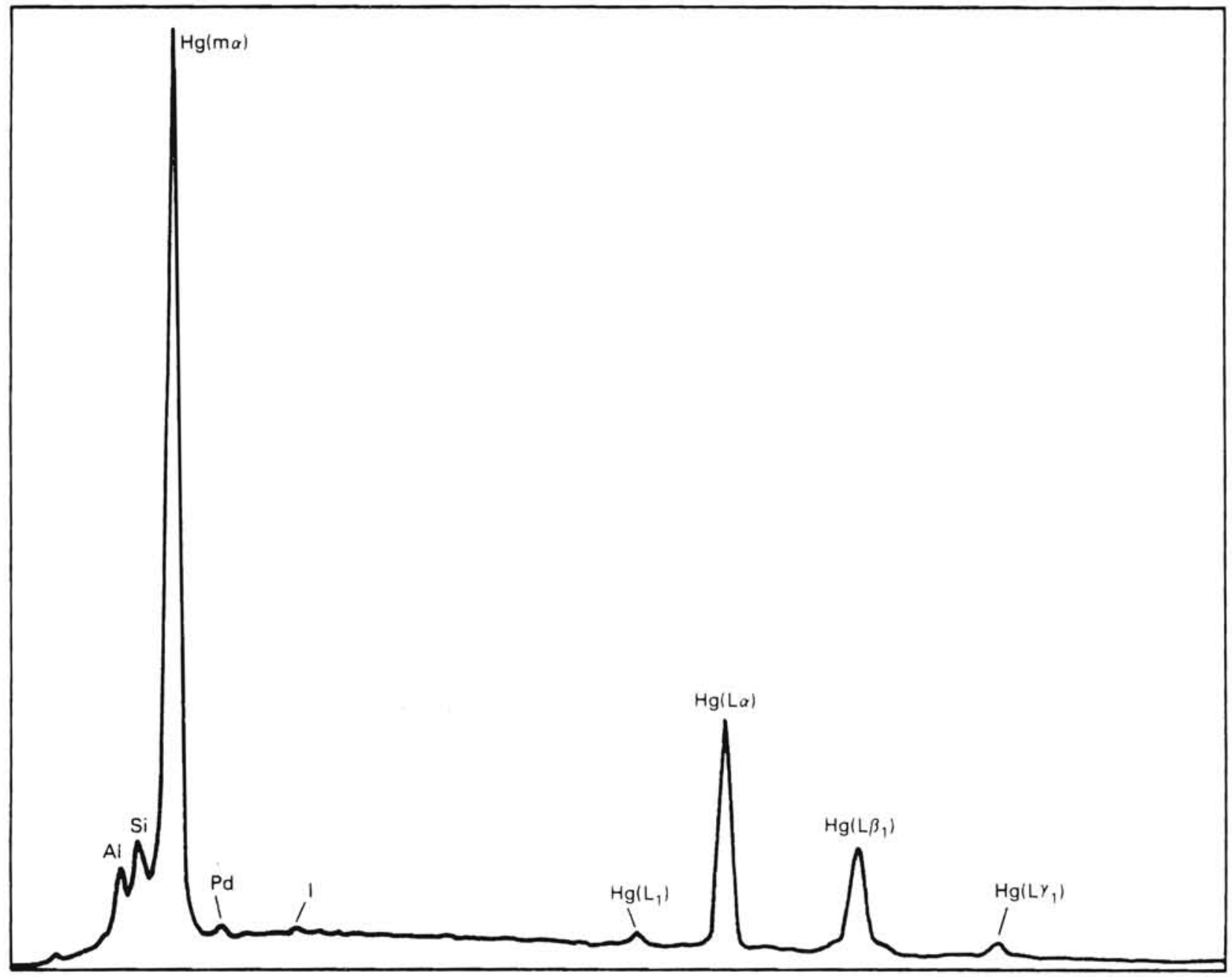

FIGURE 4.9. X-Ray Micrograph of Venturi Solid Sample Flat Feature (Point Number 2) from Experiment No. 5

the simulated waste, off-gas outlet temperature, and oxygen content in system atmosphere). The variation in oxygen content of the vitrification system atmosphere produced the greatest difference in chemical behavior of mercury and iodine. This is a result of iodine and chlorine formation which are dependent on the gas phase composition.

Mercury is essentially completely volatized from the vitrification system. Mercury reacts strongly with iodine formed from iodide oxidation, chlorine from chloride oxidation, and oxygen. At low ratios of iodine to mercury (0.1) the reaction between mercury and iodine is essentially complete. At high iodine 


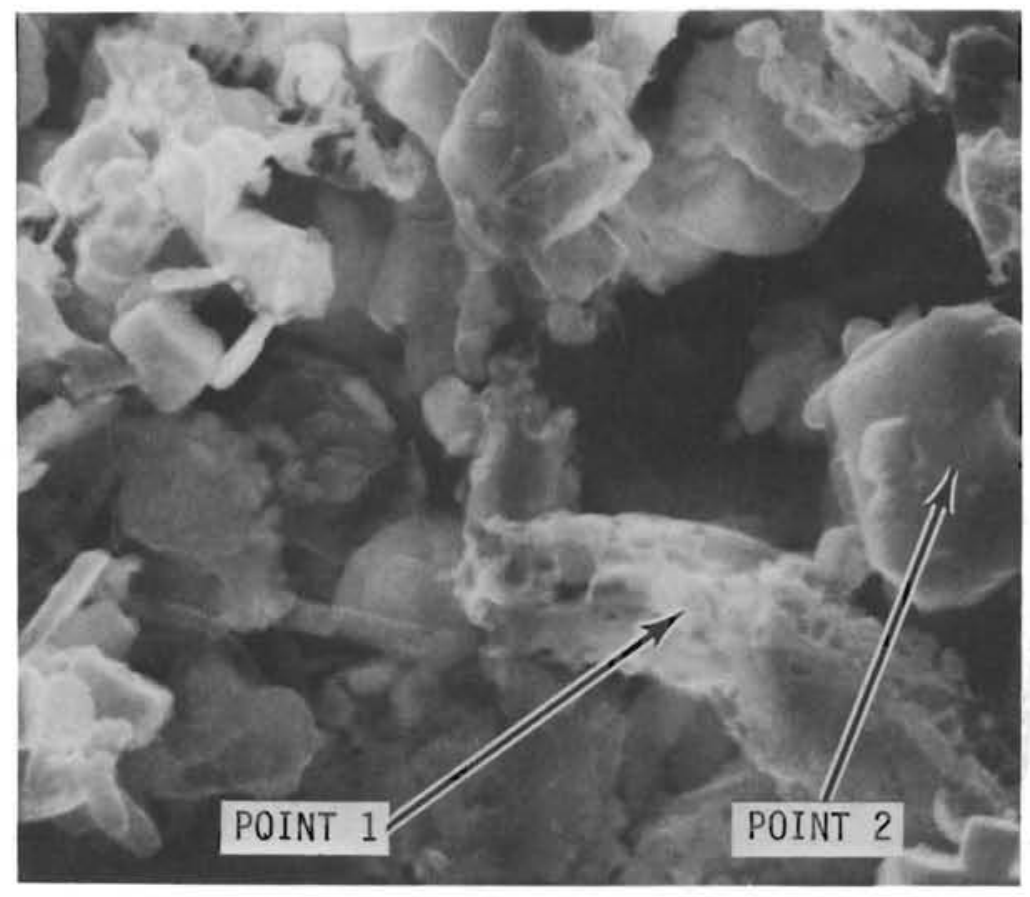

PHOTO 4.4. Photograph of Mercury Solids Collected From Venturi Solution, Experiment No. 7 Showing $\mathrm{HgCl}$ and $\mathrm{HgI}$ Particulate $(10,000 \mathrm{X})$

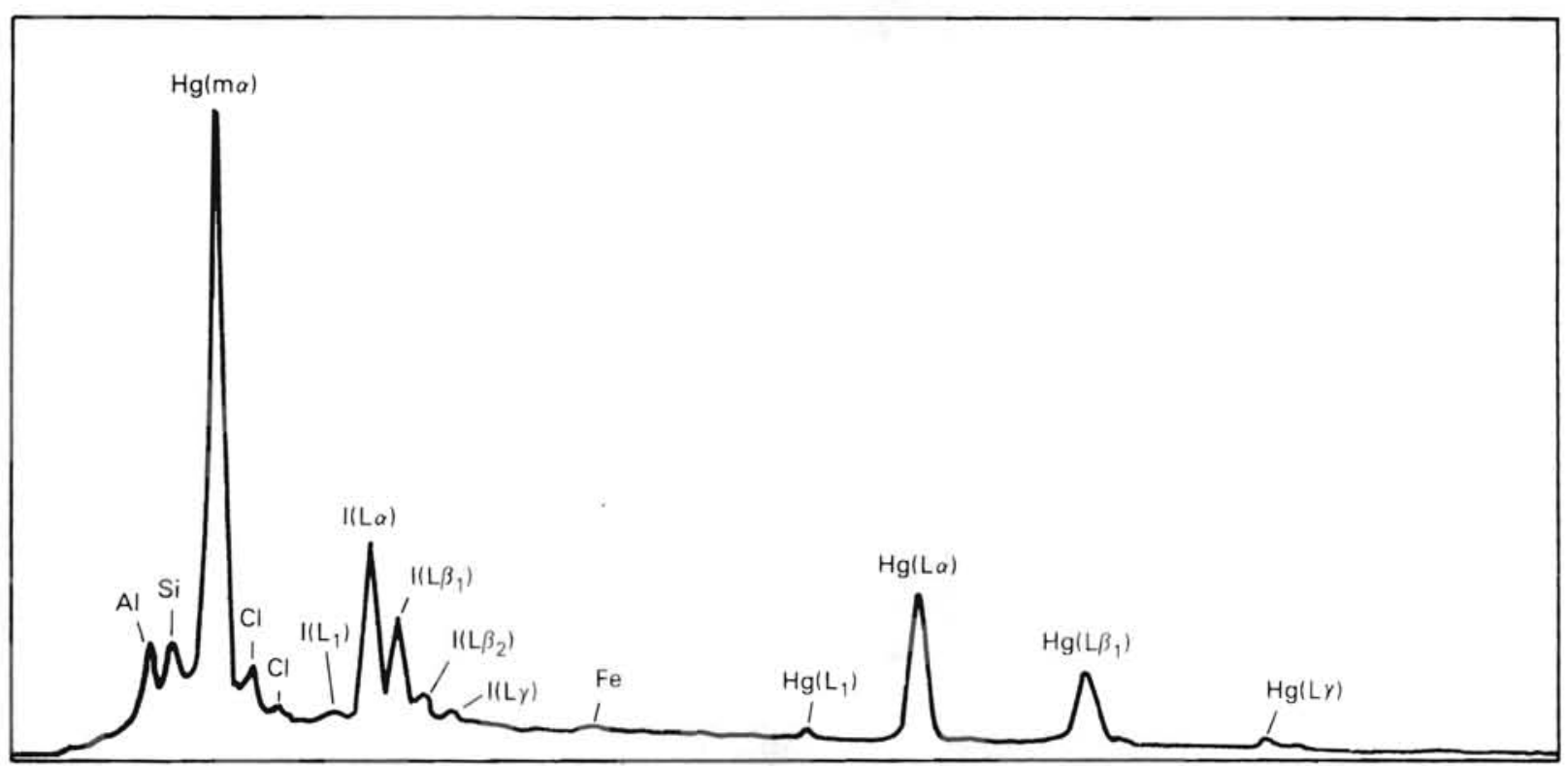

FIGURE 4.10. X-Ray Micrograph of Venturi Solid Sample, HgI Particle from Experiment No. 7 (Point Number 1) 


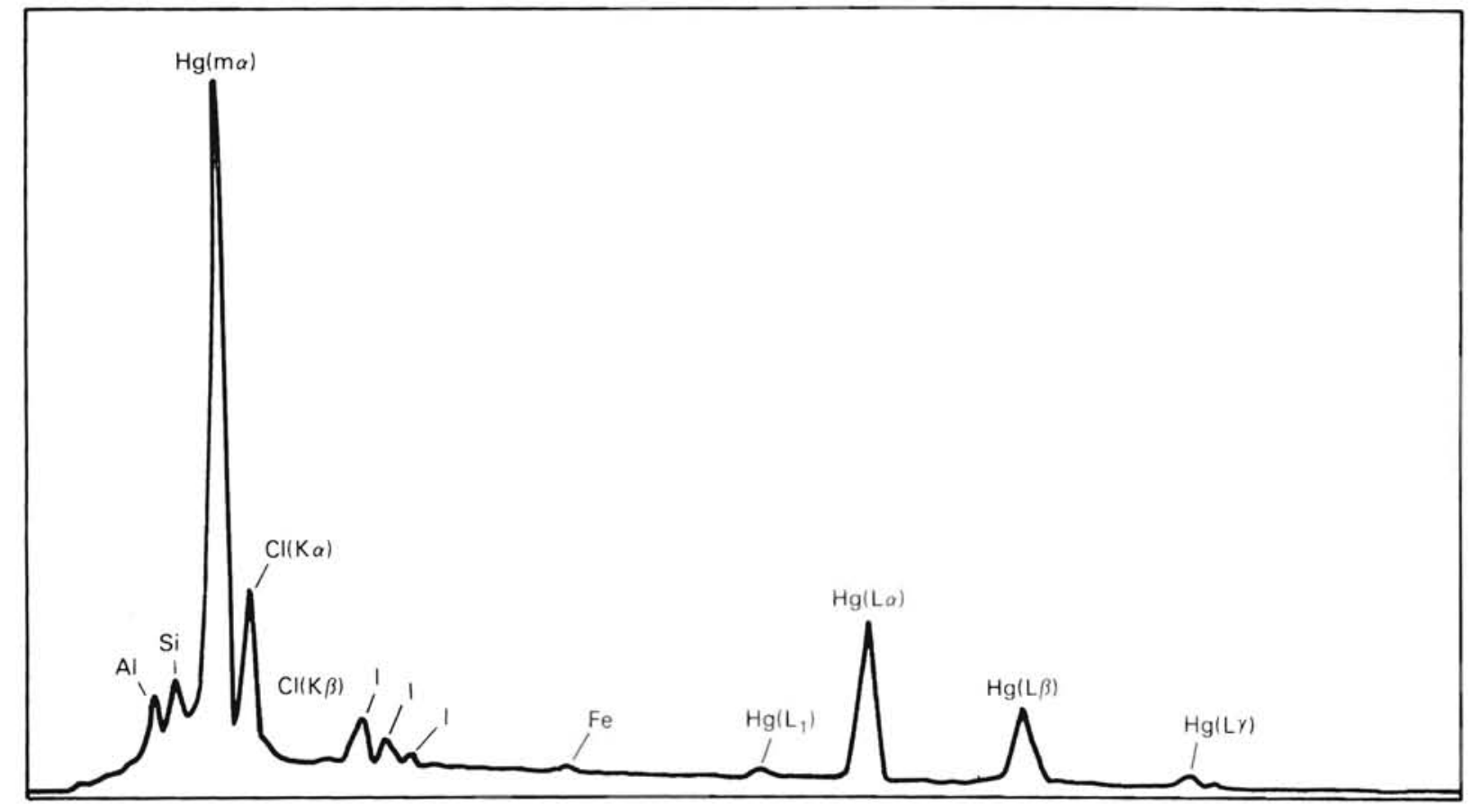

FIGURE 4.11. X-Ray Micrograph of Venturi Solid Sample, HgCl Particle from Experiment No. 7 (Point Number 2)

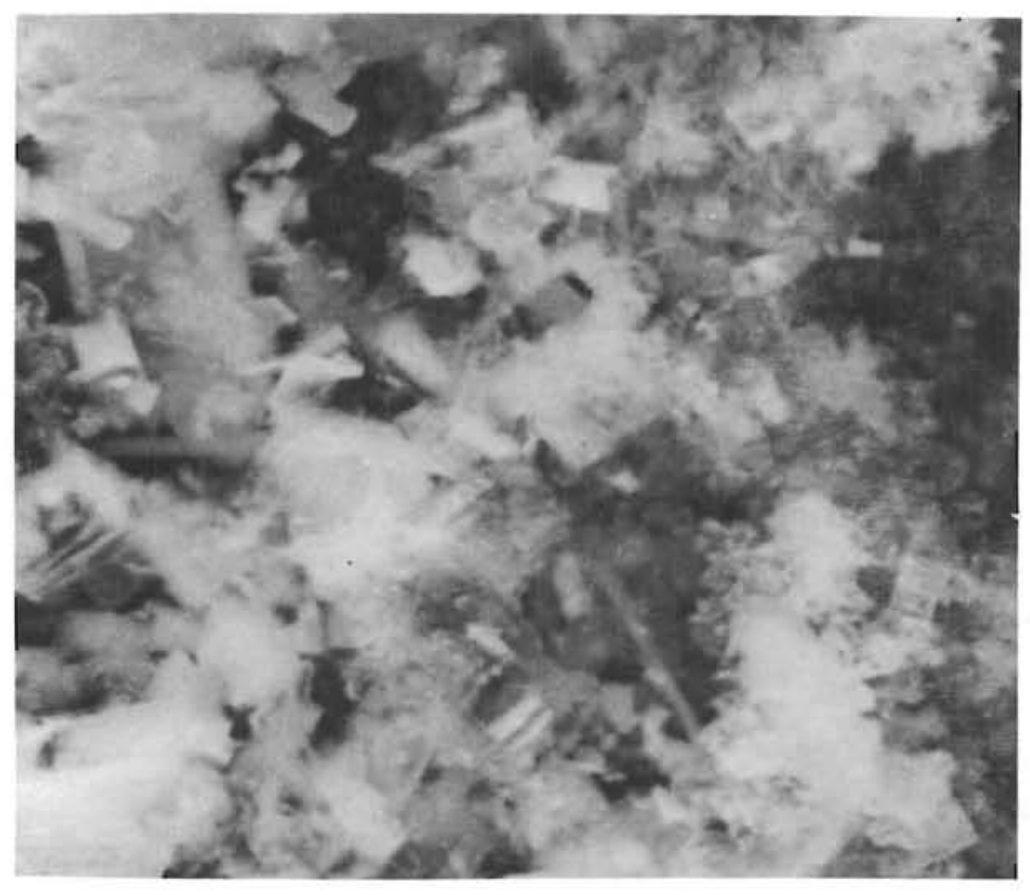

PHOTO 4.5. Photograph of Mercury Solids Collected From Venturi Solution, Experiment No. 8 Showing HgI Particulate $(10,000 \mathrm{X})$ 


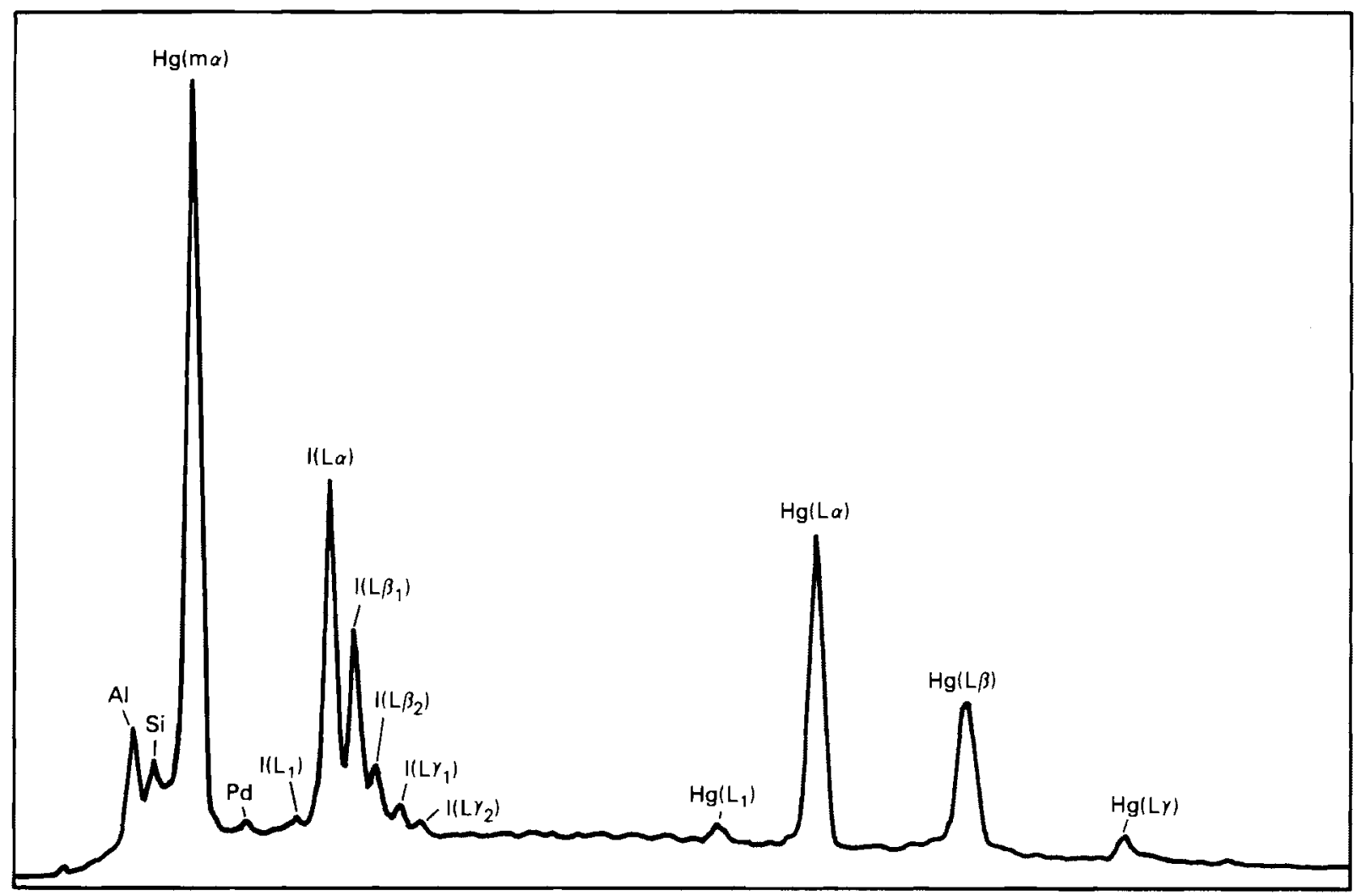

FIGURE 4.12. X-Ray Micrograph of Venturi Solid Sample and General Area Scan from Experiment Number 8

to mercury ratios (0.9), the interaction between mercury and iodine is only partially complete. This is the result of competition between chlorine and iodine for reaction with mercury.

The iodide chemical behavior is strongly dependent upon the vitrification system atmosphere. A vitrification system atmosphere containing 20 vol\% oxygen tends to oxidize the majority ( 85 to $97 \%$ ) of the iodide to iodine. The iodine volatizes from the vitrification process. The majority of the iodine reacts with mercury and consequently is trapped as a particulate. The remainder of the iodine ( 10 to $30 \%$ ) was estimated to be volatized from the off-gas cleanup process based upon material balances. Iodide not oxidized, representing 3 to 15 wt\% remains in the vitreous product.

Operating the vitrification system at conditions where little oxygen is present tends to keep the iodide in the reduced state. The majority (27 to $55 \mathrm{wt} \%)$ of the iodide remains with the vitreous product. The remainder of the 
iodide is oxidized and volatized to react with mercury in the gas phase. The mercuric iodide is recovered by off-gas scrubbing or deposited within the offgas piping.

Scrub solution solids collected from the experiments in which there was a low oxygen content in the vitrification system atmosphere contained higher concentrations of mercury. Metallic mercury was also present in these solids in small concentrations. The exact quantity of metallic mercury could not be determined.

The majority of the mercury recovered from the scrub solution was in the mercurous or plus one oxidation state. Based on thermodynamics the mercurous state is unstable at the vitrification system temperatures of 700 to $1100^{\circ} \mathrm{C}$. The following explanation may account for these observations. Mercury ion may be reduced to mercury metal by nitrate decomposition within the calcine particles (as shown in the reaction below). Iodide ion is oxidized by the oxygen present forming volatile $\mathrm{I}_{2}$. Mercury metal reacts directly with $\mathrm{I}_{2}$ in the gas phase, forming $\mathrm{HgI}_{2}$ which then volatizes.

$$
\mathrm{Hg}^{+2}+\mathrm{NO}_{3}^{-}-\mathrm{Hg}^{\mathrm{O}}+\mathrm{NO}_{2}+\frac{1}{2} \mathrm{O}_{2}
$$

Upon condensation in the scrub solution, the mercuric iodide disproportionates via the following reaction, limited by the excess mercury metal $\left(\mathrm{Hg}^{\circ}\right)$ in the system.

$$
\mathrm{Hg}^{\mathrm{O}}+\mathrm{HgI}_{2}=\mathrm{Hg}_{2} \mathrm{I}_{2}
$$

The $\mathrm{Hg}_{2} \mathrm{I}_{2}$ compound is much more insoluble forming a precipitate. The disproportionation reaction is driven to the right by the low solubility of the $\mathrm{Hg}_{2} \mathrm{I}_{2}$ compound and the predominance of the mercury metal in the system. A similar mechanism is proposed for the pressure of the mercurous chloride compound. Only small quantities of mercury were detected in the solution above the solids (conc $\sim 100 \mathrm{ppm}$ ). This indicates that the disproportionation is essentially complete. 
Recoveries of mercury and iodide in the experimental system were not quantitative. Unrecovered mercury ranged from 37 to $90 \mathrm{wt} \%$. It is believed that all the mercury was contained in the vitrification system by the cold trap created with the off-gas condenser. The unrecovered mercury is deposited in the off-gas piping as solid material similar in composition to the recovered solids. Some of the iodide not recovered is tied up with the mercury. The deposition of these mercury solids may lead to off-gas plugging problems in long-term operations. 


\subsection{DEVELOPMENT WORK NEEDED}

The experimental results have indicated the need for further development and verification testing. Areas needing study include:

1) Assess the buildup of the mercury solids in the vitrification system off-gas piping.

2) Develop methods for quantitative recovery of mercury from the alkaline Purex waste prior to vitrification.

3) Mercury corrosion potential in the exposed metal in the vitrification and off-gas system.

4) Evaluate methods to separate the mercury solids from the scrub solution, and to recover mercury from the scrub solution solids. 


\subsection{REFERENCES}

Cochran, W. G. and G. M. Cox. 1957. Experimental Designs. Second Edition. John Wiley and Sons, Inc., New York, New York.

Cotton, F. A. and G. Wilkinson. 1972. Advanced Inorganic Chemistry. Third Edition. Wiley-Interscience, New York, New York.

E. I. duPont deNemours and Co. 1980. Preliminary Technical Data Summary for the Defense Waste Processing Facility, Stage 1. DPSTD-80-38, Savannah River Laboratory, Aiken, South Carolina.

Gray, L. W., M. Y. Donnan, B. Y. Okamoto. 1979. Chemical Characterization of SRP Waste Tank Sludges and Supernates. USDOE Report DP-1483, E. I. duPont deNemours and Company, Savannah River Laboratory, Aiken, South Carolina.

Hepler, L. G. and G. 0lofsson. 1975. "Mercury: Thermodynamic Properties, Chemical Equilibria and Standard Potentials," Chem. Rev. 75(5)585-602.

King, E. J. 1959. Qualitative Analysis and Electrolyte Solutions. Harcourt, Brace and World, Inc., New York, New York.

Koch, W. H. and W. Licht. 1980. "New Design Approach Boosts Cyclone Efficiency," Separation Techniques 2: Gas/Liquid/Solid Systems, McGraw-Hill Publishing Company, New York, New York.

Landon, L. F. 1980. Preliminary Technical Data Summary No. 3 for the Defense Waste Processing Facility. DPSTD-77-13-3. Savannah River Laboratory, Aiken, South Carolina.

Lindsay, W. L. 1979. Chemical Equilibria in Soils. Wiley-Interscience, New York, New York.

Ondrejcin, R. S. 1974. Chemical Compositions of Supernates Stored in SRP High-Level Waste Tanks, USAEC Report DP-1374, E. I. duPont deNemours and Company, Savannah River Laboratory, Aiken,. South Carolina..

Stone, J. A. 1976a. Sampling and Analyses of SRP High-Level Waste Sludges. USERDA Report DP-1399, E. I. duPont deNemours and Company, Savannah River Laboratory, Aiken, South Carolina..

Stone, J. A. 1976b. Separation of SRP Waste Sludge and Supernate. USERDA Report DP-1441, E. I.. duPont deNemours and Company, Savannah River Laboratory, Aiken, South Carolina.

Stone, J. A., S. T. Goforth, Jr., P. K. Smith. 1979. Preliminary Evaluation of Alternative Forms for Immobilization of Savannah River Plant High-Level Waste. USDOE Report DP-1545, E. I. duPont deNemours and Company, Savannah River Laboratory, Aiken, South Carolina. 
Stul1, D. R. and H. Prophet. 1971. JANAF Thermochemical Tables, Second Edition, NBS-37, National Bureau of Standards, Washington, D.C.

Weast, R. C. 1968. Handbook of Chemistry and Physics. Forty-ninth Edition. Chemical Rubber Company, Cleveland, Ohio.

Wicks, C. E. and F. E. Block. 1963. Thermodynamic Properties of 65 Elements-Their 0xides, Halides, Carbides and Nitrides. BuTletin 605, Bureau of Mines, Washington, DC. 
APPENDIX A

SIMULATED WASTE PREPARATION 



\section{SIMULATED WASTE PREPARATION}

Simulated alkaline waste for the vitrification process was prepared by precipitation of metallic nitrates and batch washing of the resultant sludge to remove $\mathrm{Na}^{+}, \mathrm{NO}_{3}{ }^{-}, \mathrm{NO}_{2}^{-}$and $\mathrm{SO}_{4}{ }^{-2}$. The physical and chemical characteristics of of the precipitated feed are anticipated to be similar to actual SRP waste.

The procedure for the precipitated waste preparation was based on information obtained from D. W. Jones of Savannah River Laboratory along with chemical adjustments required to more accurately represent a reference SRP alkaline waste composition.

Three, 300-L simulated waste batches were prepared for the experimental study. Each $300 \mathrm{~L}$ waste batch yielded approximately $100 \mathrm{~L}$ of alkaline waste sludge that could be used in the mercury study experiments. The procedure utilized for preparation of a 300-L batch of precipitated waste is outlined below.

\section{A.1 PRECIPITATION OF $\mathrm{MnO}_{2}$}

$2.16 \mathrm{~L}$ of $50 \% \mathrm{Mn}\left(\mathrm{NO}_{3}\right)_{2}$ solution is mixed with $20.4 \mathrm{~L}$ of water (the resultant blend is transferred to a $300-\mathrm{L}$ tank). $948 \mathrm{~g}$ of $\mathrm{KMnO}_{4}$ is dissolved in $19.8 \mathrm{~L}$ of water. While agitating the $\mathrm{Mn}\left(\mathrm{NO}_{3}\right)_{2}$ solution, the $\mathrm{KMnO}_{4}$ solution is added.

\section{A.2 METALLIC NITRATE AND SODIUM SALT PREPARATION}

The following metallic nitrates and sodium salts are added to $25.2 \mathrm{~L}$ of water. The solution is warmed to $35^{\circ} \mathrm{C}$ and agitated. The resultant chemical blend is added to the $\mathrm{MnO}_{2}$ slurry prepared in Step A.1.

\begin{tabular}{|c|c|}
\hline Compound & Weight, $g$ \\
\hline $\mathrm{Al}\left(\mathrm{NO}_{3}\right)_{3}-9 \mathrm{H}_{2} \mathrm{O}$ & 11,400 \\
\hline $\mathrm{NaNO}_{3}$ & 3,360 \\
\hline $\mathrm{FeSO}_{4}-7 \mathrm{H}_{2} \mathrm{O}$ & 13,800 \\
\hline $\mathrm{Ca}\left(\mathrm{NO}_{3}\right)_{2}-4 \mathrm{H}_{2} \mathrm{O}$ & 1,380 \\
\hline
\end{tabular}




$$
\begin{array}{lr}
\text { Compound } & \text { Weight, } \mathrm{g} \\
{\left(\mathrm{NO}_{3}\right)_{2}-6 \mathrm{H}_{2} \mathrm{O}} } & 2,220 \\
\mathrm{Fe}\left(\mathrm{NO}_{3}\right)_{2}-6 \mathrm{H}_{2} \mathrm{O} & 17,400 \\
\mathrm{Hg}\left(\mathrm{NO}_{3}\right)_{2} & 1,280
\end{array}
$$

\section{A.3 PRECIPITATION OF SLUDGE}

$120 \mathrm{~kg}$ of $50 \% \mathrm{NaOH}$ solution is added to $78 \mathrm{~L}$ of water. The solution is allowed to cool and is then added to the solution formed by mixing the solutions from Steps A.1 and A.2. The combined solution is agitated and cooled, as necessary, to maintain the temperature at 35 to $40^{\circ} \mathrm{C}$ during caustic addition.

\section{A.4 ADDITION OF NONREACTANTS AND FISSION PRODUCT}

The following nonreactive chemicals and fission product elements are added to $22 \mathrm{~L}$ of water. The mixture is agitated and the chemicals are allowed to dissolve. The mixture is combined with the simulated waste blend.

\begin{tabular}{lll}
\multicolumn{1}{c}{ Compound } & & \multicolumn{2}{c}{ Weight, $\mathrm{g}$} \\
$\mathrm{NaNO}_{2}$ & & 9,360 \\
$\mathrm{Na}_{2} \mathrm{CO}_{3}$ & & 2,520 \\
$\mathrm{SiO}_{2}$ & 1,260 \\
$\mathrm{Sr}\left(\mathrm{NO}_{3}\right)_{2}$ & & 3,360 \\
$\mathrm{Cs}\left(\mathrm{NO}_{3}\right)$ & & 1,260 \\
$\mathrm{Ru}\left(\mathrm{NO}^{\prime}\right)\left(\mathrm{NO}_{3}\right)$ & & $1,800 \mathrm{ml}(70 \mathrm{gm} \mathrm{Ru})$ \\
$\mathrm{Ba}\left(\mathrm{NO}_{3}\right)_{2}$ & 540 \\
$\mathrm{Ce}\left(\mathrm{NO}_{3}\right)_{3}-6 \mathrm{H}_{2} \mathrm{O}$ & 3,000 \\
$\mathrm{TeO}$ & & 1,740
\end{tabular}

\section{A.5 SLUDGE WASHING}

The blended chemical solution is agitated for approximately $1 \mathrm{~h}$. The agitator is then turned off, and the solids formed from neutralization reactions are allowed to settle for about $48 \mathrm{~h}$. A sludge layer settles to approximately $50 \%$ of the tank volume during this time. The supernate above the sludge 
containing cesium, sodium, nitrate and sulphate is sampled and pumped out of the tank. The precipitated sludge was then agitated and sampled. Water was added to double the volume, and the mixture was agitated for approximately $45 \mathrm{~min}$. The solution was allowed to settle, and the sampling/sludge-washing procedure continued until the sodium, nitrate and sulphate concentrations fell below limits of $5 \mathrm{wt} \%, 10 \mathrm{wt} \%$, and $3 \mathrm{wt} \%$, respectively on a dry-weight basis in the sludge. Six or seven wash steps were required to meet this specification.

The settling rates for the sludge mixtures are shown graphically in Figure A.1 and A.2. The sludge-settling rates increase as the difference in specific gravity between the sludge and supernate increases, which occurs with each wash step. The specific gravity of the sludge and supernate are shown graphically in Figure A.3 as a function of wash step.

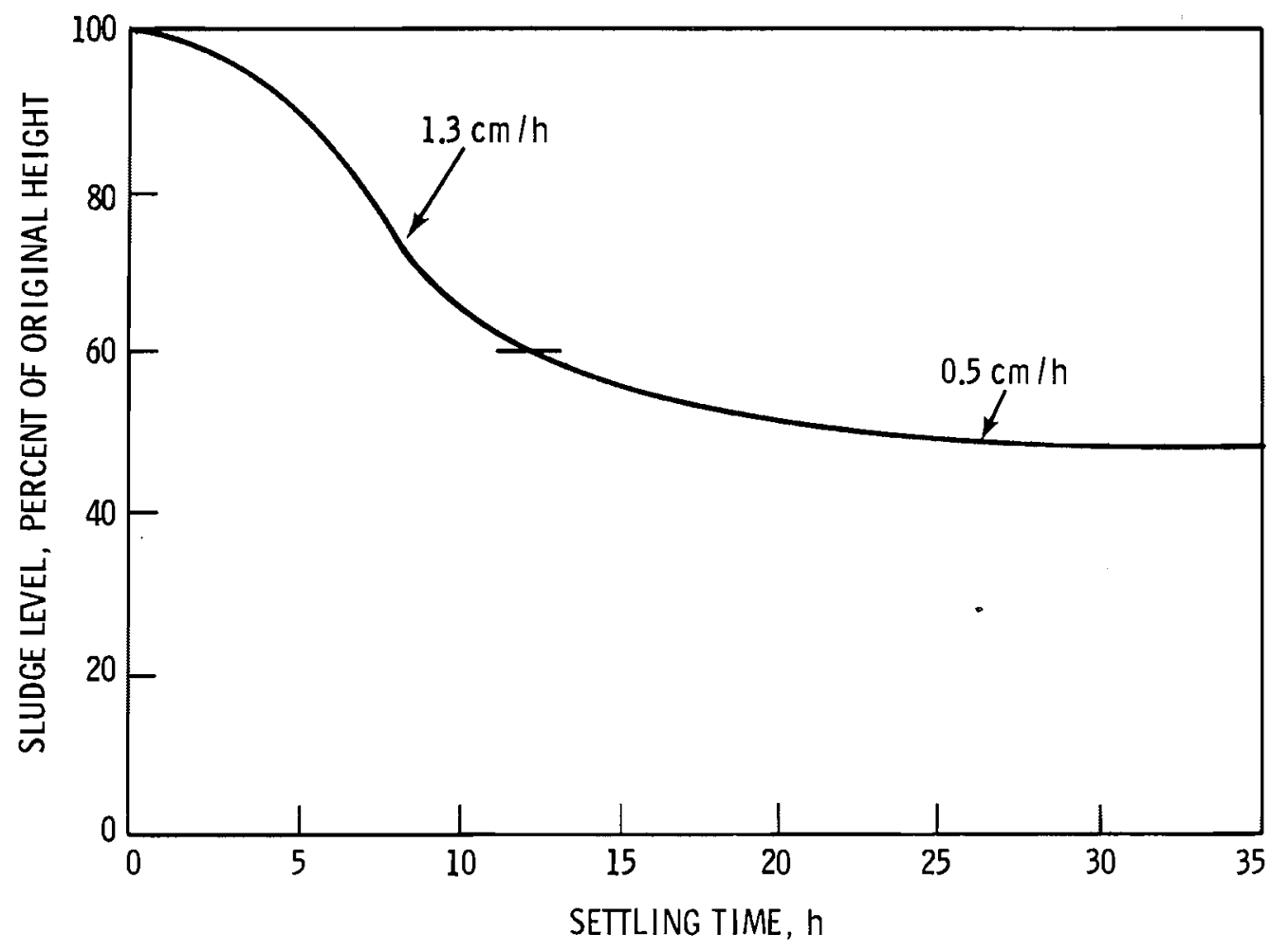

FIGURE A.1. Sludge Settling During Initial and First Washing 


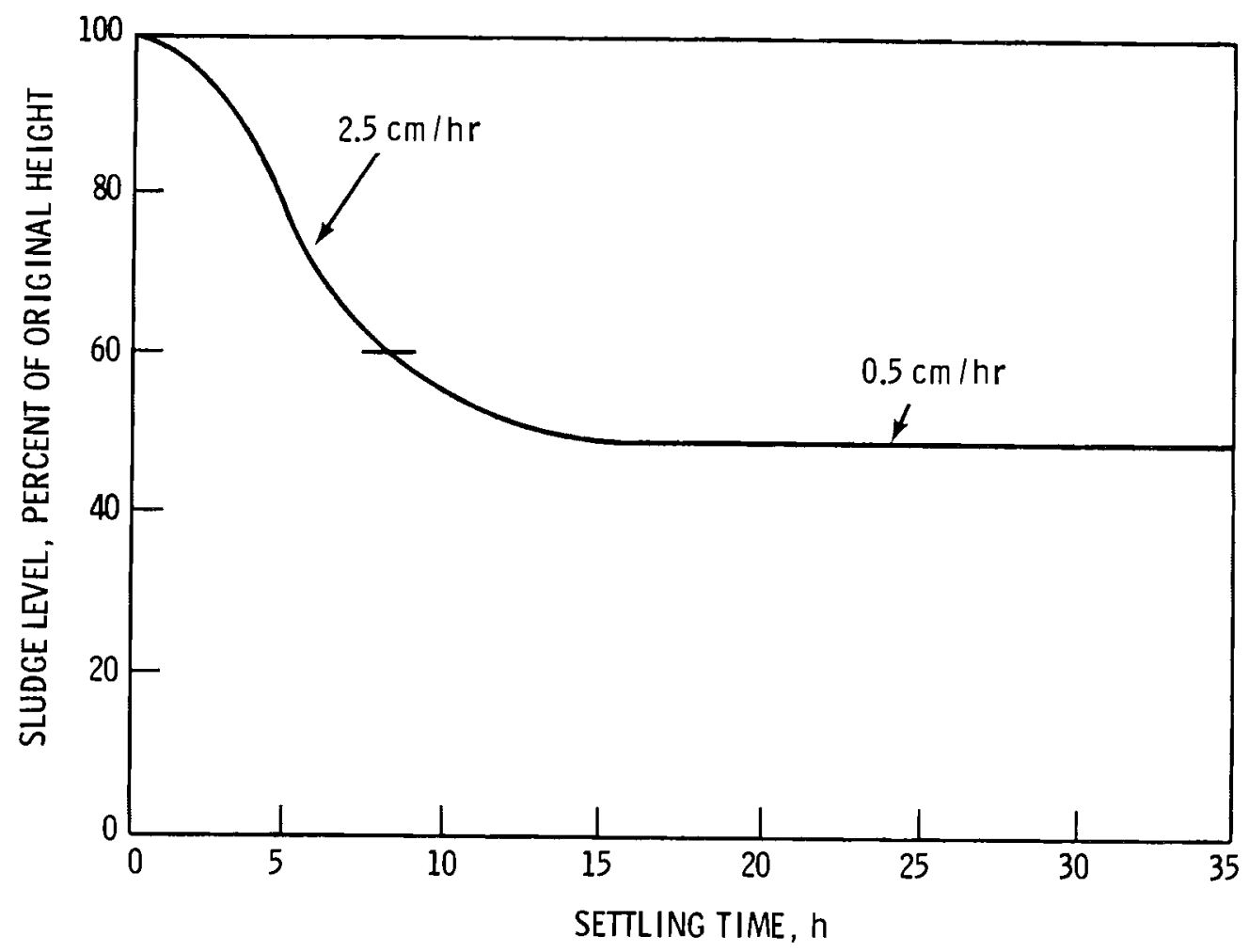

FIGURE A.2. Sludge Settling During Second to Sixth Washing

The weight of select soluble cations and anions in the sludge are shown in Figure A.4 and A.5 as a function of wash step for a typical feed batch. Soluble chemical components are sodium potassium, sulfate nitrate, and nitrite. Slightly soluble chemical components are cesium, aluminum and tellurium. Components which are insoluble included cerium, manganese, ruthenium, mercury, nickel, barium, strontium and calcium.

The $\mathrm{pH}$ of the solution during sludge washing varied from 13.5 during initial separation to 12.0 during the seventh wash step. Buffering action due to the presence of carbonate in the sludge is thought to keep the $\mathrm{pH}$ relatively constant between each wash step.

The electrical conductivity of the supernate as a function of wash step is shown in Figure A.6. This data indicates that the use of a conductivity probe to determine the relative amount of soluble species in the supernate is possible. This technique can be used rather than chemical analysis to determine when sludge washing is sufficiently complete to meet required specifications. 


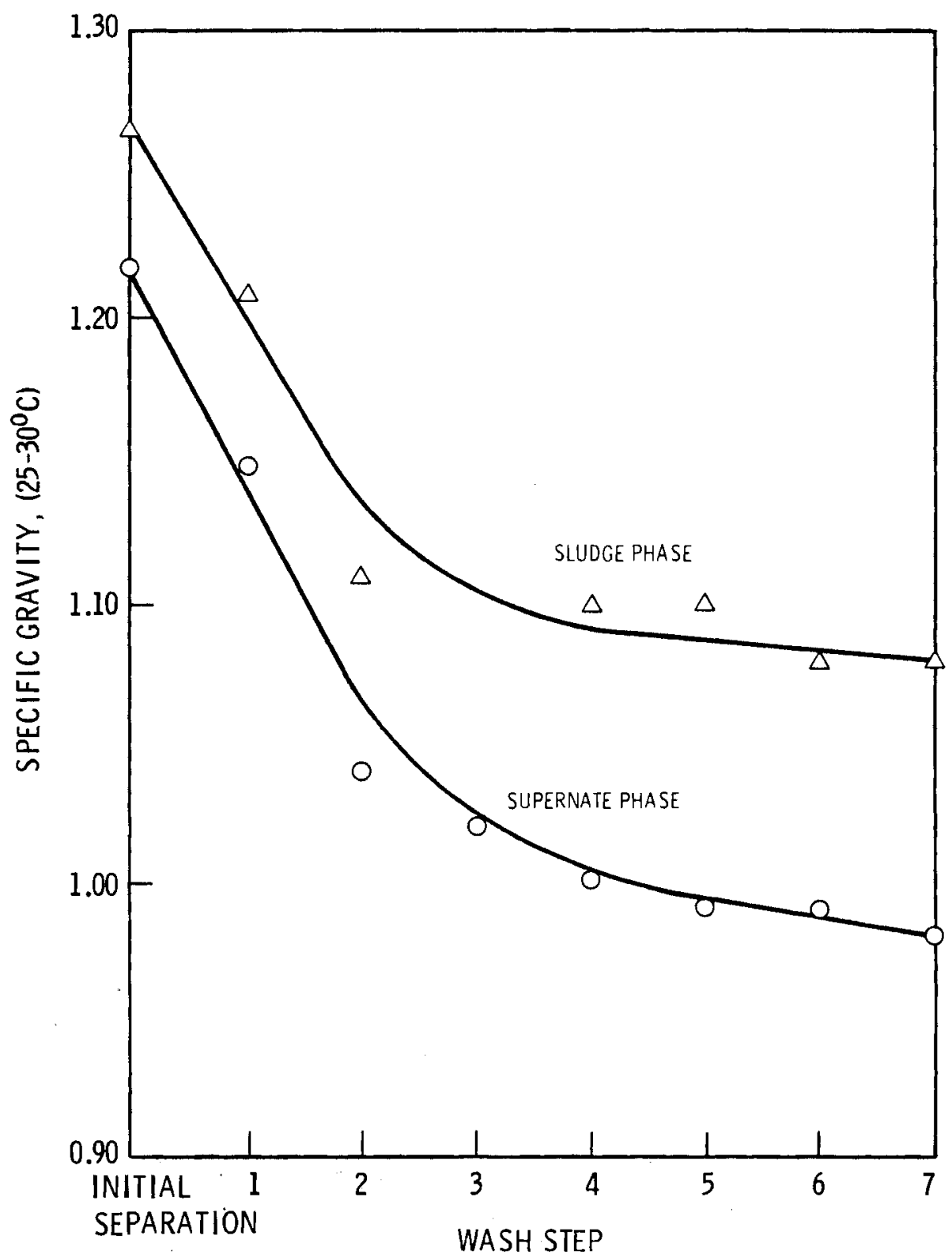

FIGURE A.3. Specific Gravity of Supernate and Sludge as a Function of Wash Step

The simulated alkaline waste composition is compared with the waste composition taken from the reference Defense Waste Processing Facility Flowsheet (DWPF) (DPSTD-77-13-3) and the reference DWPF Flowsheet for Stage 1 (DPSTD 80-30) in Table A.1. In general, the concentration of each chemical constituent in the simulated feed is 40 to $60 \%$ below the reference flowsheet composition. This is due to the dilute nature of the simulated waste. 


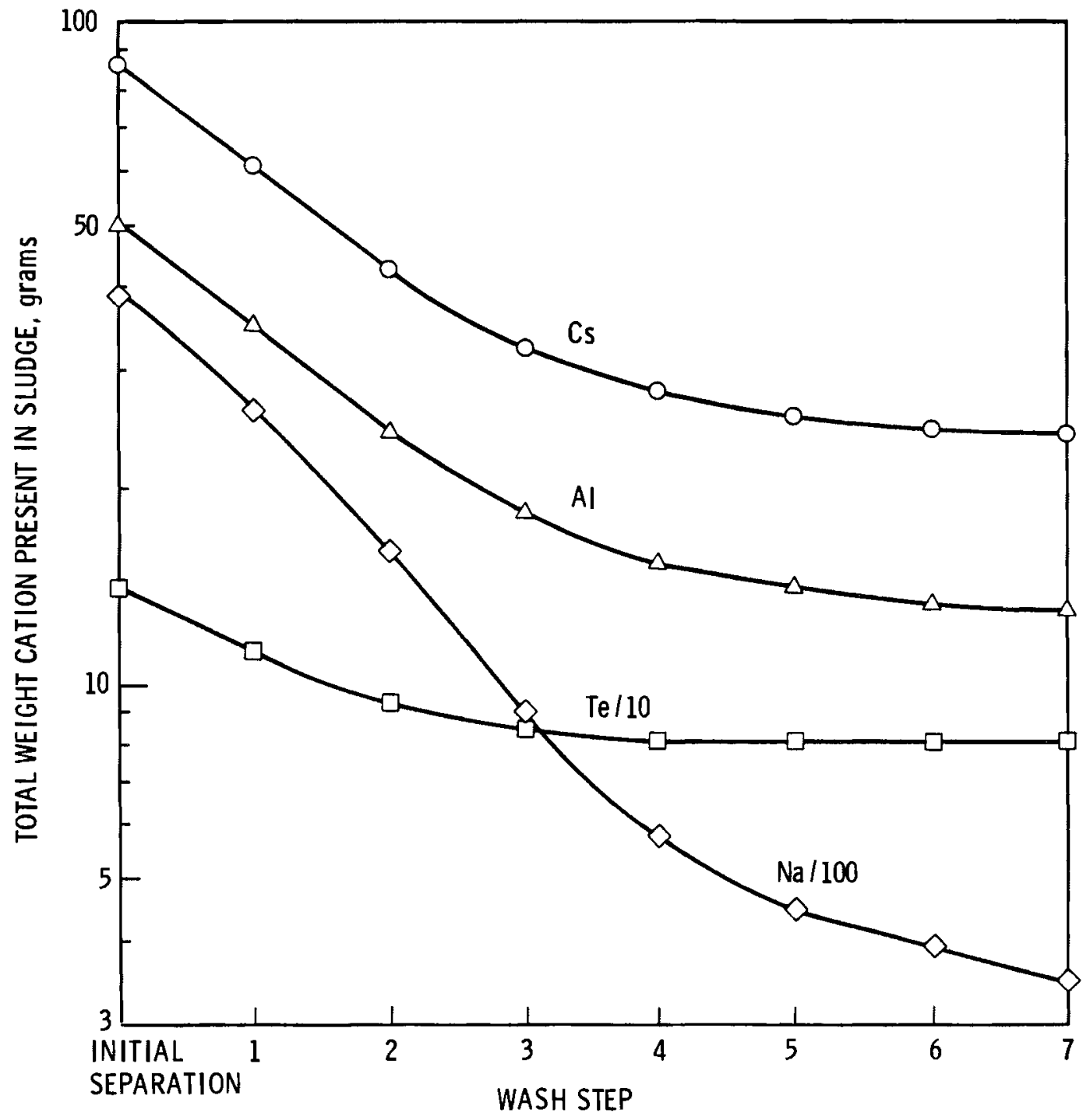

FIGURE A.4. Weight of Soluble Cation Versus Wash Step

Adjustments were made in the simulated feed composition to adjust key chemical components to reference flowsheet levels. Chemical components routinely added in these adjustment were chloride, iodide, and fluoride. 


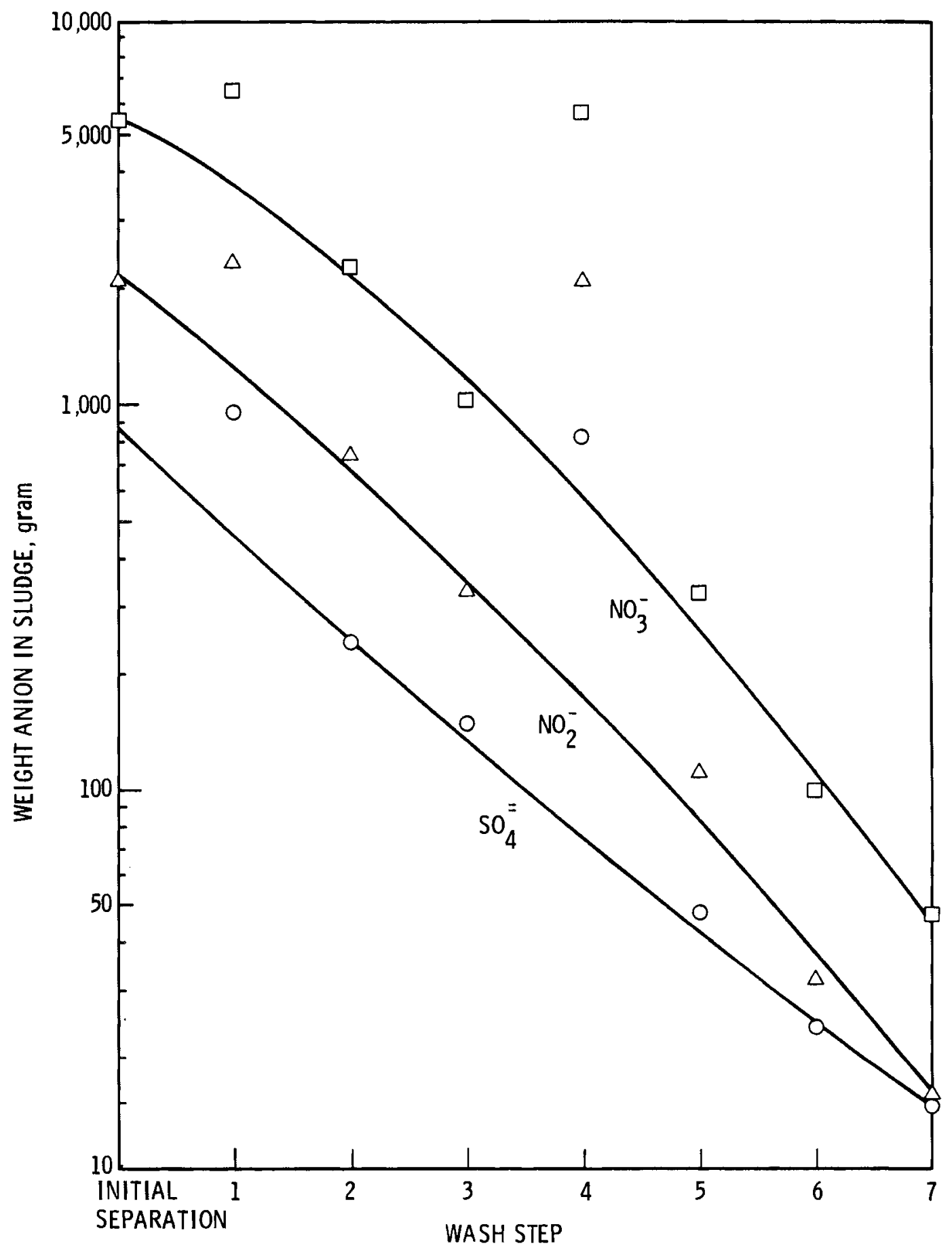

FIGURE A.5. Weight of Soluble Anion Versus Wash Step 


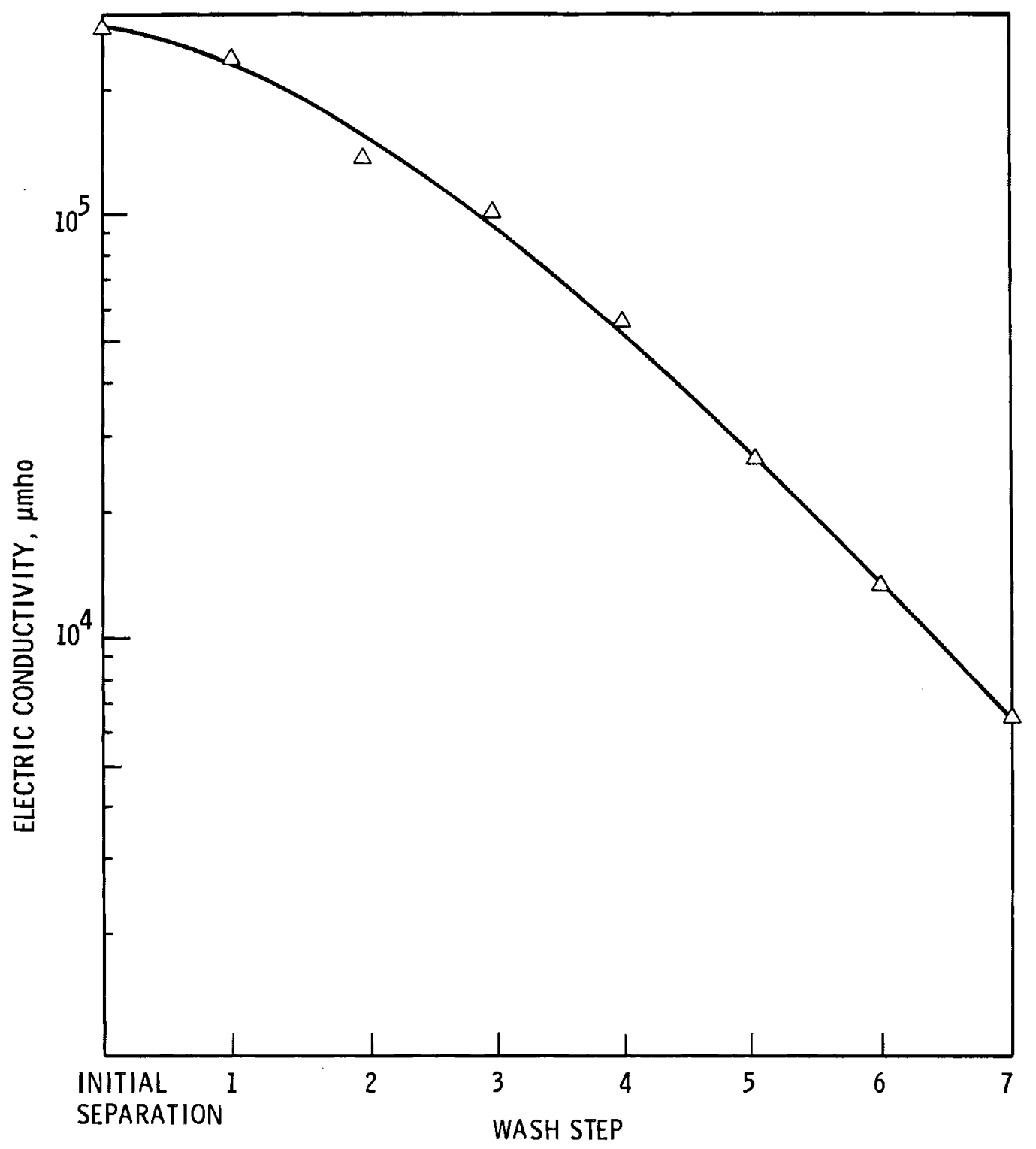

FIGURE A.6. Electric Conductivity of Supernate as a Function of wash Step, Sludge Washing Experiments 
TABLE A.1. Comparison of Reference Alkaline Waste Compositions With Simulated Alkaline Waste Composition Range

\begin{tabular}{|c|c|c|c|}
\hline $\begin{array}{l}\text { Chemical } \\
\text { Component }\end{array}$ & $\begin{array}{c}\text { Reference }(a, b) \\
\text { Composition, } \\
\mathrm{g} / \mathrm{L} \\
\end{array}$ & $\begin{array}{c}\text { Reference }(a, c) \\
\text { Composition, } \\
\mathrm{g} / \mathrm{L} \\
\end{array}$ & $\begin{array}{c}\text { Simulated Alkaline } \\
\text { Waste Composition } \\
\text { Range, } g / L \\
\end{array}$ \\
\hline Al & 6.6 & 8.6 & 0.35 to 0.49 \\
\hline $\mathrm{Ca}$ & 3.2 & 4.3 & 1.3 to 2.9 \\
\hline $\mathrm{Fe}$ & 42.7 & 57.1 & 25 to 41 \\
\hline $\mathrm{Na}$ & 1.6 & 2.0 & 1.6 to 8.2 \\
\hline Mn & 10.9 & 14.2 & 4.1 to 6.6 \\
\hline $\mathrm{Ni}$ & 5.9 & 7.9 & 2.4 to 3.1 \\
\hline Si & 1.9 & - & 0.15 to 0.61 \\
\hline $\mathrm{Hg}$ & 6.0 & 3.4 & 3.4 to 6.2 \\
\hline $\mathrm{Cl}$ & 1.2 & 1.3 & 0.02 to 4.0 \\
\hline $\mathrm{F}$ & 0.13 & 0.16 & 0.001 to 0.8 \\
\hline I & 4.5 & 0.60 & 0.09 to 3.0 \\
\hline $\mathrm{NO}_{3}$ & 0.60 & 0.46 & 0.25 to 4.0 \\
\hline $\mathrm{NO}_{2}$ & 0.20 & 0.17 & 0.10 to 0.90 \\
\hline $\mathrm{SO}_{4}$ & 0.12 & 0.096 & 0.10 to 0.83 \\
\hline Cs & 0.01 & 0.025 & 0.02 to 0.18 \\
\hline $\mathrm{Sr}$ & 0.06 & 0.01 & 7.2 to 9.4 \\
\hline $\mathrm{Ru}$ & 0.54 & 0.09 & 0.25 to 0.30 \\
\hline $\mathrm{Ba}$ & 0.006 & 0.014 & 1.6 to 2.0 \\
\hline $\mathrm{Ce}$ & 0.14 & 0.026 & 7.4 to 8.8 \\
\hline Te & 0.02 & 0.004 & 4.0 to 4.7 \\
\hline
\end{tabular}

(a) Fission product compositions, excluding iodine, based on 5-yr aged waste.

(b) Landon, L.F. 1980. Preliminary Technical Data Summary No. 3 for the Defense Waste Processing Facility. DPSTD-77-13-3, Savannah River Laboratory, Aiken, South Carolina.

(c) E.I. duPont de Nemours \& Co. 1980. Preliminary Technical Data Summary for the Defense Waste Processing Facility, Stage 1. DPSTD-80-38, Savannah River Laboratory, Aiken, South CaroTina. 


\section{APPENDIX B}

SUMMARY OF EXPERIMENTAL RUNS 
.

$\because$ 
APPENDIX B

\section{SUMMARY OF EXPERIMENTAL RUNS}

Process data from the twelve experimental runs completed during this study is summarized in this appendix. This data was included to provide the reader with information on system operating performance.

Summarized in Table B.1 is the lab-scale spray calciner/in-can melter system operating performance. Experimental tests had an averaged five hours in length, during which an average 18-L of simulated waste was solidified producing an average of $6.2 \mathrm{~kg}$ of glass product.

Waste feed rates varied throughout the testing due to the different spray nozzles used and modification made to the nozzles. Better overall performance in the spray calciner spraying system was achieved during the latter runs when the nozzle dimensions had been optimized. The simulated feed slurry contained many solids, resulting in frequent nozzle pluggage. An automatic cleanout needle was used to keep the feed flow as continuous as possible. However, the best performance was achieved by enlargement of the orifice on the fluid cap. Upper limits on the waste feed rate are controlled by the power output of the calciner furnace used to dry the waste. Because of this small volume atomizing nozzles are required.

The calciner furnace has five separate heating zones powered by the same power source. Temperature control was provided by a thermocouple located in Zone-4, and controlled at a temperature of 750 to $800^{\circ} \mathrm{C}$. Because of this there is a wide variation in the temperature profile in the calciner barrel. The lower temperatures are at the top where the heat load due to waste drying is greatest. Controlling the temperature by the upper zone would provide excessive heating on the bottom zones limiting the heater lifetime.

There is a wide variation in temperature within the filter housing. The influence of the calciner barrel heating the filters is seen by the higher temperatures on the bottom of the filters. The filter heaters were automatically controlled by a thermocouple located in the off-gas of the filter outlet to the 
required temperature. The filter material used was Incone1-600. The operating temperature 1 imit of $600^{\circ} \mathrm{C}$ on the filter material was exceeded during those tests when an off-gas outlet temperature of $600^{\circ} \mathrm{C}$ was used. No excessive damage to the filters was noticed during the relatively short experimental project.

Table B.2 summarizes the waste compositions for each experiment. A comparison of these composition ranges with the reference SRP waste compositions was presented in Appendix A. The iodide composition was the only composition intentionally varied. This was done to adjust the iodide to mercury molar ratio.

TABLE B.2. Chemical Composition of Simulated Alkaline Purex Wastes for Mercury Study Experiments

Average Concentrations ( $\mathrm{g} / \mathrm{L})$

Experiment Number

\begin{tabular}{|c|c|c|c|c|c|c|c|c|c|c|c|c|}
\hline $\begin{array}{c}\begin{array}{c}\text { Element } \\
\text { ion }\end{array} \\
\end{array}$ & 1 & 2 & 3 & 4 & 5 & 6 & 7 & 8 & 9 & 10 & 11 & 12 \\
\hline $\mathrm{A} 1$ & 0.44 & 0.39 & 0.44 & 0.49 & 0.44 & 0.42 & 0.48 & 0.49 & 0.45 & 0.35 & 0.46 & 0.49 \\
\hline $\mathrm{Ba}$ & 2.0 & 1.9 & 2.0 & 2.06 & 1.81 & 1.72 & 1.9 & 1.9 & 2.0 & 1.6 & 2.0 & 2.2 \\
\hline $\mathrm{Ca}$ & 1.6 & 1.5 & 1.8 & 1.91 & 2.27 & 2.81 & 3.0 & 2.9 & 1.7 & 1.3 & 1.74 & 1.8 \\
\hline $\mathrm{Fe}$ & 27 & 25.6 & 28.1 & 40.9 & 36.9 & 35.0 & 39.1 & 37.2 & 25.0 & 20.0 & 26.8 & 27.7 \\
\hline $\mathrm{Hg}$ & 6.2 & 4.1 & 4.3 & 5.2 & 4.7 & 4.8 & 5.1 & 5.4 & 4.5 & 3.4 & 4.6 & 4.5 \\
\hline K & 0.40 & 0.70 & 0.46 & 0.09 & 0.04 & 0.06 & 1.0 & 1.0 & 0.13 & 0.64 & 0.8 & 0.8 \\
\hline $\mathrm{Mg}$ & 0.09 & 0.07 & 0.07 & 0.09 & 0.08 & 0.08 & 0.09 & 0.09 & 0.09 & 0.07 & 0.08 & 0.09 \\
\hline$M n$ & 8.1 & 5.7 & 6.4 & 5.9 & 5.6 & 5.4 & 6.2 & 6.6 & 5.2 & 4.1 & 5.4 & 5.6 \\
\hline $\mathrm{Na}$ & 3.6 & 3.4 & 4.3 & 4.06 & 4.6 & 5.5 & 8.2 & 7.2 & 2.2 & 1.56 & 3.7 & 4.2 \\
\hline $\mathrm{Ni}$ & 3.1 & 2.5 & 3.4 & 3.08 & 2.71 & 2.58 & 2.9 & 2.8 & 3.1 & 2.4 & 3.2 & 3.3 \\
\hline $\mathrm{Si}$ & 0.15 & 0.20 & 0.20 & 0.39 & 0.20 & 0.16 & 0.25 & 0.50 & 0.52 & 0.61 & 0.7 & 1.2 \\
\hline $\mathrm{Cl}$ & 1.21 & 0.93 & 0.86 & 0.013 & 0.057 & 0.33 & 3.2 & 3.96 & 2.1 & 0.93 & 1.54 & 0.77 \\
\hline $\mathrm{F}$ & 0.082 & 0.067 & 0.067 & 0.001 & 0.003 & 0.006 & 0.14 & 0.18 & 0.80 & 0.40 & 0.080 & 0.055 \\
\hline I & 1.0 & 0.14 & 0.84 & 0.27 & 0.09 & 0.09 & 2.6 & 2.9 & 0.29 & 1.6 & 2.3 & 0.32 \\
\hline $\mathrm{NO}_{3}$ & 2.5 & 1.47 & 1.47 & 3.4 & 1.9 & 4.3 & 2.9 & 3.0 & 0.50 & 0.25 & 0.34 & 0.80 \\
\hline $\mathrm{NO}_{2}$ & 0.30 & $N P$ & $N P$ & 0.41 & 0.32 & 0.90 & 0.90 & $N P$ & 0.20 & 0.10 & 0.08 & 0.03 \\
\hline $\mathrm{SO}_{4}$ & 0.35 & $N P$ & NP & 0.60 & 0.50 & 0.83 & 0.50 & 0.50 & 0.23 & 0.10 & 0.23 & 0.49 \\
\hline Cs & 0.056 & 0.035 & 0.02 & 0.032 & 0.16 & 0.18 & 0.15 & 0.18 & 0.02 & 0.017 & 0.016 & 0.020 \\
\hline $\mathrm{Sr}$ & 9.4 & 9.1 & 10.3 & 9.2 & 8.1 & 7.7 & 8.7 & 8.3 & 9.3 & 7.2 & 9.6 & 10.0 \\
\hline
\end{tabular}

NP--Analysis not performed 
TABLE B.1. Summary of Lab-Scale Spray Calciner/In-Can Melter Operating Performance

\begin{tabular}{|c|c|c|c|c|c|c|c|c|c|c|c|c|}
\hline$\frac{\text { Exper iment Number }}{\text { Date Conducted }}$ & $\frac{\text { LSSC-01 }}{12 / 31 / 80}$ & $\frac{\text { LSSC-02 }}{1 / 7 / 81}$ & $\frac{\text { LSSC- } 03}{1 / 9 / 81}$ & $\frac{\text { LSSC-04 }}{1 / 19 / 81}$ & $\frac{L S S C-05}{1 / 30 / 81}$ & $\frac{\text { LSSC-06 }}{2-4-81}$ & $\frac{\text { LSSC- } 07}{2-13-81}$ & $\frac{\text { LSSC-08 }}{2 / 18 / 81}$ & $\begin{array}{l}\text { LSSC-09 } \\
1 / 26 / 81\end{array}$ & $\frac{\text { LSSC-10 }}{3 / 2 / 81}$ & $\frac{L S S C-11}{3 / 5 / 81}$ & $\frac{\text { LSSC-12 }}{3 / 31 / 81}$ \\
\hline \multicolumn{13}{|l|}{ Waste Feed Data } \\
\hline \multirow{2}{*}{ 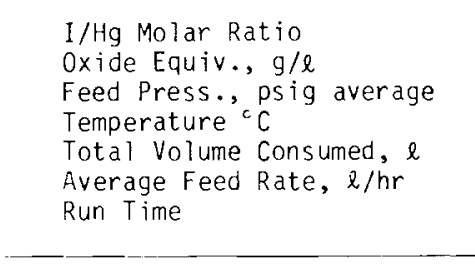 } & 0.9 & \multirow{2}{*}{$\begin{array}{l}0.1 \\
89 \\
20 \\
20 \\
13.9 \\
2.8 \\
5 \mathrm{hr} 23 \mathrm{~min}\end{array}$} & \multirow{2}{*}{$\begin{array}{l}0.9 \\
82 \\
20 \\
15 \\
16 \\
4.2 \\
4 \text { hr } 35 \mathrm{~min}\end{array}$} & \multirow{2}{*}{$\begin{array}{l}0.1 \\
150 \\
18 \\
28 \\
18.4 \\
3.8 \\
6 \mathrm{hr} 10 \mathrm{~min}\end{array}$} & 0.1 & 0.1 & 0.9 & 0.9 & 0.1 & 0.9 & 0.9 & 0.1 \\
\hline & $\begin{array}{l}20 \\
19 \\
13.2 \\
2.4 \\
6 \mathrm{hr}\end{array}$ & & & & $\begin{array}{l}16 \\
35 \\
21.7 \\
4.0 \\
5 \mathrm{hr} 45 \mathrm{~min}\end{array}$ & $\begin{array}{l}14 \\
34 \\
17.4 \\
3.9 \\
5 \mathrm{hr}, 32 \mathrm{~min}\end{array}$ & $\begin{array}{l}14 \\
33 \\
15.9 \\
3.9 \\
5 \mathrm{hr} 15 \mathrm{~min}\end{array}$ & $\begin{array}{l}14 \\
36 \\
17.7 \\
4.7 \\
5 \mathrm{hr}\end{array}$ & $\begin{array}{l}23 \\
30 \\
18.8 \\
5 \\
4 \mathrm{hr}\end{array}$ & $\begin{array}{l}21 \\
19 \\
18.6 \\
4.56 \\
4 \text { hr } 18 \mathrm{~min}\end{array}$ & $\begin{array}{l}18 \\
28 \\
25.4 \\
5.5 \\
4 \mathrm{hr} 25 \mathrm{~min} \\
\end{array}$ & $\begin{array}{l}17 \\
24 \\
23.2 \\
4.9 \\
6 \mathrm{hr}\end{array}$ \\
\hline \multicolumn{13}{|l|}{ Feed Nozzile } \\
\hline $\begin{array}{l}\text { Manuf acture Spray Systems } \\
\text { Air cap. No. } \\
\text { Fluid Cap No. } \\
\text { Atomizing Gas } \\
\text { Atom Air Press., psig } \\
\text { Atom Air Flow, scfm }\end{array}$ & $\begin{array}{l}73160 \mathrm{SS}(\mathrm{a}) \\
2850 \mathrm{SS}(\mathrm{d}) \\
\text { Air } \\
20 \\
0.57-0.68\end{array}$ & $\begin{array}{l}73160 \mathrm{Ss}(\mathrm{d}) \\
2850 \mathrm{SS}(\mathrm{d}) \\
\text { Air } \\
22 \\
1.1\end{array}$ & $\begin{array}{l}73160 \mathrm{SS}(\mathrm{a}) \\
2850 \mathrm{SS}(\mathrm{d}) \\
\text { Air } \\
20 \\
1.1-1.25\end{array}$ & $\begin{array}{l}73160 \mathrm{Ss}(\mathrm{a}) \\
2850 \mathrm{SS}(\mathrm{d}) \\
\text { Air } \\
23 \\
0.6-0.8\end{array}$ & $\begin{array}{l}73160 \mathrm{SS}(\mathrm{a}) \\
2850 \mathrm{SS}(\mathrm{e}) \\
95 \% \mathrm{Ar}, 5 \% \mathrm{H}_{2} \\
20 \\
0.65-0.9\end{array}$ & $\begin{array}{l}.73160 \mathrm{Ss}(\mathrm{a}) \\
2850 \mathrm{SS}(\mathrm{e}) \\
95 \% \mathrm{Ar}, 5 \% \mathrm{H} 2 \\
22 \\
0.9\end{array}$ & $\begin{array}{l}73160 \mathrm{SS}(\mathrm{a}) \\
2850 \mathrm{SS}(\mathrm{e}) \\
\mathrm{Ar} 95 \% \mathrm{H}_{2} 5 \% \\
22 \\
0.9\end{array}$ & $\begin{array}{l}73160 \mathrm{Ss}(\mathrm{a}) \\
2850 \mathrm{SS}(\mathrm{e}) \\
\mathrm{Ar} 95 \% \mathrm{H}_{2} 5 \% \\
22 \\
0.85\end{array}$ & $\begin{array}{l}67147(\mathrm{~b}) \\
2850 \mathrm{Ss}(\mathrm{e}) \\
\text { Air } \\
25 \\
0.5\end{array}$ & $\begin{array}{l}67147(\mathrm{~b}) \\
2850 \mathrm{SS}(\mathrm{e}) \\
\text { Air } \\
25 \\
0.6-0.8\end{array}$ & $\begin{array}{l}67147(\mathrm{c}) \\
2850 \mathrm{Ss}(\mathrm{e}) \\
\text { Air } \\
20 \\
0.5-0.8\end{array}$ & $\begin{array}{l}67147(\mathrm{c}) \\
285 \mathrm{SS}(\mathrm{e}) \\
\mathrm{Ar} 95 \% \mathrm{H}_{2} 5 \% \\
25 \\
0.7\end{array}$ \\
\hline \multicolumn{13}{|l|}{ Frit } \\
\hline $\begin{array}{l}\text { Total Frit ysed, } \mathrm{kg} \\
\text { Average Frit Rate, } \\
\text { Frit to Feed Ratio, } \mathrm{g} / \mathrm{h}\end{array}$ & $\begin{array}{l}2.1 \\
350 \\
148\end{array}$ & $\begin{array}{l}1.65 \\
306 \\
110\end{array}$ & $\begin{array}{l}1.6 \\
350 \\
85\end{array}$ & $\begin{array}{l}5.5 \\
892 \\
232\end{array}$ & $\begin{array}{l}2.5 \\
435 \\
110\end{array}$ & $\begin{array}{l}2.85 \\
515 \\
134\end{array}$ & $\begin{array}{l}4.25 \\
810 \\
252\end{array}$ & $\begin{array}{l}2.2 \\
440 \\
108\end{array}$ & $\begin{array}{l}2.3 \\
575 \\
116\end{array}$ & $\begin{array}{l}1.7 \\
395 \\
86\end{array}$ & $\begin{array}{l}2.2 \\
518 \\
90\end{array}$ & $\begin{array}{l}2.7 \\
450 \\
93\end{array}$ \\
\hline \multicolumn{13}{|l|}{ Spray calciner } \\
\hline \multirow{3}{*}{ 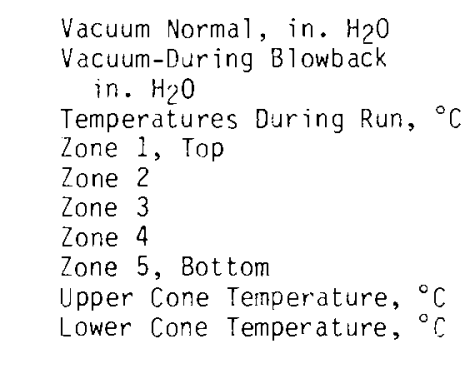 } & $6-10.8$ & 5 & 4.5 & 4 & 6 & 5 & 1.5 & 4 & 5 & 4 & 5 & 3 \\
\hline & 1 & 1 & 1 & 1 & 2 & 1 & 0 & 0 & 1 & 0 & 1 & 0 \\
\hline & $\begin{array}{l}480-575 \\
620=685 \\
710=740 \\
750=805 \\
735=810 \\
325=375 \\
340=375\end{array}$ & $\begin{array}{l}500-610 \\
605=700 \\
675=735 \\
705=750 \\
700=715 \\
260=330 \\
280=340\end{array}$ & $\begin{array}{l}520=620 \\
630=715 \\
715=750 \\
750=790 \\
710=805 \\
290=370 \\
330=390\end{array}$ & $\begin{array}{l}515-640 \\
615=710 \\
720=765 \\
735=770 \\
725=780 \\
170=365 \\
160-370\end{array}$ & $\begin{array}{l}470-570 \\
590=650 \\
705=745 \\
750=800 \\
715=820 \\
250=320 \\
265=335\end{array}$ & $\begin{array}{l}460=580 \\
510=665 \\
700=740 \\
750=780 \\
710=790 \\
230=315 \\
240=310\end{array}$ & $\begin{array}{l}400-475 \\
525-620 \\
775-720 \\
740=800 \\
710=815 \\
245-345 \\
265-340\end{array}$ & $\begin{array}{l}425-590 \\
500=670 \\
670=770 \\
735=805 \\
740=835 \\
300=410 \\
335=400\end{array}$ & $\begin{array}{l}450-580 \\
565-660 \\
720=735 \\
740=760 \\
690=770 \\
215=320 \\
240-320\end{array}$ & $\begin{array}{l}480-580 \\
565=650 \\
690=725 \\
730=780 \\
685=805 \\
360=395 \\
285=385\end{array}$ & $\begin{array}{l}490-555 \\
545=625 \\
660=710 \\
715=775 \\
670=795 \\
220=325 \\
235-340\end{array}$ & $\begin{array}{l}485-555 \\
540=620 \\
665=715 \\
710=790 \\
670=815 \\
265=360 \\
295-365\end{array}$ \\
\hline \multicolumn{13}{|l|}{ In Can Melter } \\
\hline $\begin{array}{l}\text { Top Zone Temp. },{ }^{\circ} \mathrm{C} \\
\text { Lower Zone Temp., }{ }^{\circ} \mathrm{C}\end{array}$ & $\begin{array}{r}880-907 \\
1015-1040\end{array}$ & $\begin{array}{r}895-910 \\
1020=1050\end{array}$ & $\begin{array}{r}925-955 \\
1040-1060\end{array}$ & $\begin{array}{l}865-905 \\
925-1035\end{array}$ & $\begin{array}{r}900-935 \\
1035-1050\end{array}$ & $\begin{array}{r}890-930 \\
1010-1050\end{array}$ & $\begin{array}{r}855-925 \\
1000-1055\end{array}$ & $\begin{array}{r}935-940 \\
1045-1055\end{array}$ & $\begin{array}{r}880-925 \\
1010-1040\end{array}$ & $\begin{array}{r}850-890 \\
1000-1030\end{array}$ & $\begin{array}{r}890-925 \\
1030-1040\end{array}$ & $\begin{array}{r}885-915 \\
1025-1045\end{array}$ \\
\hline
\end{tabular}

(a) Factory air cap opening $0.059 \mathrm{in}$.

c) Factory air cap drilled out to 0.052 in.

(d) Factory fluid cap opening 0.0176 in. 

TABLE B.1. (contd)

\begin{tabular}{|c|c|c|c|c|c|c|c|c|c|c|c|c|}
\hline Experiment Number & LSSC-01 & LSSC-02 & LSSC-03 & LSSC-04 & LSSC-05 & LSSC-06 & LSSC -07 & LSSC-08 & LSSC-09 & LSSC-10 & LSSC-11 & LSSC-12 \\
\hline \multicolumn{13}{|l|}{ Canister } \\
\hline \multirow{2}{*}{$\begin{array}{l}\text { Canister Number } \\
\text { Weight of Glass Produced, } \mathrm{kg} \\
\text { Weight of Loose Material } \mathrm{kg} \\
\text { Weight of Nonvitifified Material } \\
\text { in - Barrel-Cone-Canister, } \mathrm{g}\end{array}$} & \multirow[t]{2}{*}{$\begin{array}{l}1 \\
6.48 \\
0.05\end{array}$} & \multirow[t]{2}{*}{$\begin{array}{l}2.9 \\
0.98 \\
0.06\end{array}$} & $\begin{array}{l}3 \\
4.0 \\
0.08\end{array}$ & \multirow[t]{2}{*}{$\begin{array}{l}4 \\
7.85 \\
0.27\end{array}$} & $\begin{array}{l}5 \\
3.96 \\
-\end{array}$ & $\begin{array}{l}6 \\
6.01 \\
0.43\end{array}$ & $\begin{array}{l}7 \\
5.67 \\
0.24\end{array}$ & \multirow[t]{2}{*}{$\begin{array}{l}8 \\
4.19 \\
0.40\end{array}$} & \multirow[t]{2}{*}{$\begin{array}{l}9 \\
4.43 \\
0.51\end{array}$} & \multirow[t]{2}{*}{$\begin{array}{l}10 \\
2.98 \\
0.24\end{array}$} & \multirow[t]{2}{*}{$\begin{array}{l}11 \\
4.41 \\
0.19\end{array}$} & \multirow[t]{2}{*}{$\begin{array}{l}12 \\
4.9\end{array}$} \\
\hline & & & 166.5 & & 735.5 & 712.8 & 242 & & & & & \\
\hline \multicolumn{13}{|l|}{ Sc off-Gas Filters } \\
\hline \multirow{2}{*}{$\begin{array}{l}\text { Bottom Filter Temperature, }{ }^{\circ} \mathrm{C} \\
\text { Middle Fitter Temperature, }{ }^{\circ} \mathrm{C} \\
\text { Top Filter Temperature, }{ }^{\circ} \mathrm{C} \text {. } \\
\text { Filter Outlet Temperature, }{ }^{\circ} \text {. } \\
\text { Filter Pressure Drop Max. } \\
\text { in. } \mathrm{H}_{2} \mathrm{O}\end{array}$} & $\begin{array}{l}305-375 \\
305=405 \\
195=240 \\
300\end{array}$ & $\begin{array}{l}325=390 \\
330=410 \\
210=250 \\
300\end{array}$ & $\begin{array}{l}410=575 \\
510=700 \\
300=450 \\
600\end{array}$ & $\begin{array}{l}480=630 \\
620=725 \\
320=480 \\
600\end{array}$ & $\begin{array}{l}520-580 \\
660=720 \\
380=470 \\
600\end{array}$ & $\begin{array}{l}235-330 \\
290=340 \\
175=240 \\
300\end{array}$ & $\begin{array}{l}300-320 \\
300=390 \\
200-220 \\
300\end{array}$ & $\begin{array}{l}550=700 \\
560=760 \\
350=450 \\
600\end{array}$ & $\begin{array}{l}300=360 \\
280=402 \\
190=235 \\
300\end{array}$ & $\begin{array}{l}690=730 \\
525=680 \\
370=450 \\
600\end{array}$ & $\begin{array}{l}325=370 \\
270=330 \\
220=250 \\
300\end{array}$ & $\begin{array}{l}650-750 \\
500-625 \\
350-475 \\
600\end{array}$ \\
\hline & 1.6 & 1.6 & 5.6 & 5.6 & 5.2 & 2 & 2 & 5.2 & 4.8 & 4.8 & 4.6 & 6.6 \\
\hline \multicolumn{13}{|l|}{ Venturi } \\
\hline $\begin{array}{l}\text { Vacuum prior to venturi } \\
\text { in of } \begin{array}{l}\text { H } 20 \\
\text { Out let Temperature, }{ }^{\circ} \mathrm{C}\end{array}\end{array}$ & $\begin{array}{l}12 \\
59\end{array}$ & $\begin{array}{l}8.5 \\
39-61.5\end{array}$ & $\begin{array}{l}8 \\
57-74\end{array}$ & $\stackrel{9}{42}-55$ & $\begin{array}{l}8 \\
41-55\end{array}$ & $\begin{array}{l}7.5 \\
49-53\end{array}$ & $\begin{array}{l}2.5-4.5 \\
39-51\end{array}$ & $\begin{array}{l}9 \\
50-59\end{array}$ & $\begin{array}{l}9 \\
59-80\end{array}$ & $\begin{array}{l}10 \\
42-56\end{array}$ & $\frac{11.5}{45-49}$ & $\begin{array}{l}10 \\
50\end{array}$ \\
\hline \multicolumn{13}{|l|}{ Scrub Solution (Water) } \\
\hline \multirow{3}{*}{$\begin{array}{l}\text { Temperature o } \\
\text { Initial Volume (1iters) } \\
\text { Volume Increase } \\
\text { Flow Rate to venturi, } \ell / h \\
\text { Press of Liquid to } \\
\text { Venturi, } i \text { psig } \\
\text { weight of } H_{g} \text { Solids } \\
\text { Collected, } g\end{array}$} & $\begin{array}{l}16 \\
10.2 \\
99.6 \\
12.3\end{array}$ & $\begin{array}{l}24 \\
10 \\
11.9 \\
29.1\end{array}$ & $\begin{array}{l}25 \\
11.9 \\
14.5 \\
32.9\end{array}$ & $\begin{array}{l}24 \\
10 \\
19.4 \\
34.8\end{array}$ & $\begin{array}{l}18 \\
10 \\
17.6 \\
29.1\end{array}$ & $\begin{array}{l}18 \\
10 \\
16.2 \\
29.1\end{array}$ & $\begin{array}{l}19 \\
10 \\
12.3 \\
29.1\end{array}$ & $\begin{array}{l}25 \\
9.4 \\
13.3 \\
35.0\end{array}$ & $\begin{array}{l}29 \\
10 \\
19.8 \\
34.0\end{array}$ & $\begin{array}{l}29 \\
9.8 \\
14.6 \\
37.1\end{array}$ & $\begin{array}{l}35 \\
9.4 \\
19.4 \\
34.8\end{array}$ & $\begin{array}{l}41 \\
10.0 \\
27.7 \\
36.7\end{array}$ \\
\hline & 21 & 20 & 20 & 20 & 22 & 22 & 22 & 22 & 22 & 23 & 23 & 23 \\
\hline & 10.3 & 12.4 & 26.4 & 20 & 25.2 & 17 & 26.5 & 21.8 & 39.4 & 63.6 & 63.1 & 22 \\
\hline \multicolumn{13}{|l|}{ Cyclone } \\
\hline \multirow{2}{*}{ 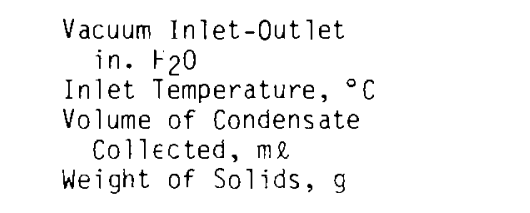 } & $40-64$ & $\begin{array}{l}9.5-10 \\
40-61\end{array}$ & $\begin{array}{l}10.5-11 \\
57-74\end{array}$ & $\begin{array}{l}10.5-{ }^{11.2} \\
58-76\end{array}$ & $\begin{array}{l}10 \\
67-76\end{array}$ & $\begin{array}{l}9-9.5 \\
66-71\end{array}$ & $\begin{array}{l}3-5.5 \\
55-71\end{array}$ & $\frac{12}{71-78}$ & $\begin{array}{l}10-17.511-18 \\
59-81\end{array}$ & $\begin{array}{l}15 \\
58-71\end{array}$ & $\begin{array}{l}17.5-18 \\
64-75\end{array}$ & $\begin{array}{l}17-17.50 \\
72-81\end{array}$ \\
\hline & $\begin{array}{l}255 \\
0.32\end{array}$ & $\begin{array}{l}165 \\
0.55\end{array}$ & $\begin{array}{l}320 \\
0.80\end{array}$ & $\begin{array}{l}450 \\
0.696\end{array}$ & $\begin{array}{l}440 \\
1.58\end{array}$ & $\begin{array}{l}225 \\
1.78\end{array}$ & $\begin{array}{l}200 \\
0.206\end{array}$ & $\begin{array}{l}265 \\
0.080\end{array}$ & $\begin{array}{l}170 \\
0.127\end{array}$ & $\begin{array}{l}180 \\
0.379\end{array}$ & $\begin{array}{l}225 \\
0.036\end{array}$ & $\begin{array}{l}335 \\
0.001\end{array}$ \\
\hline \multicolumn{13}{|l|}{ Condenser } \\
\hline $\begin{array}{l}\text { Inlet lacuum in. } \mathrm{H}_{2} \mathrm{O} \\
\text { Temperiture, Iniet-out let, } \\
\text { Volume of Condensate, ml } \\
\text { weight of Solids, } 9\end{array}$ & $\begin{array}{l}12 \\
42-59,12 \\
1700 \\
0.58\end{array}$ & $\begin{array}{l}11 \\
37-53,12 \\
1540 \\
0.99\end{array}$ & $\begin{array}{l}10-12 \\
57=71,11 \\
2125 \\
0.96\end{array}$ & $\begin{array}{l}15 \\
52-70,13 \\
3460 \\
0.254\end{array}$ & $\begin{array}{l}11 \\
61-71,12 \\
2690 \\
1.30\end{array}$ & $\begin{array}{l}10 \\
63-67,13 \\
2483 \\
3.75\end{array}$ & $\begin{array}{l}6 \\
52-67,8 \\
1855 \\
0.57\end{array}$ & $\begin{array}{l}14 \\
65-69,13 \\
2310 \\
0.96\end{array}$ & $\begin{array}{l}11-14 \\
52=71,11 \\
1960 \\
1.18\end{array}$ & $\begin{array}{l}16 \\
54-65,13 \\
1920 \\
0.94\end{array}$ & $\begin{array}{l}19 \\
47-65,13 \\
1890 \\
0.33\end{array}$ & $\begin{array}{l}18 \\
64-78,7 \\
3460 \\
1.31\end{array}$ \\
\hline \multicolumn{13}{|l|}{ Off-Gas Out let } \\
\hline Flow, (SCFM) & $1.3-1.65$ & 1.55 & $0.9-2.2$ & $0.75-1.5$ & $0.9-1.4$ & $1-1.1$ & 1.2 & $1-1.2$ & 0.9 & 1.2 & 1.2 & 1.2 \\
\hline
\end{tabular}



No. of

Copies

\section{OFFSITE}

A. A. Churm

DOE Chicago Patent Group

9800 South Cass Avenue

Argonne, IL 60439

R. Y. Lowrey/A. L. Taboas

DOE Albuquerque Operations Office

P.0. Box 5400

Albuquerque, NM 87185

S. A. Mann

DOE Chicago Operations and Region Office

Argonne, IL 60439

J. 0. Neff

Department of Energy

Columbus Program Office

505 King Avenue

Columbus, $\mathrm{OH} 43201$

W. E. Mott

DOE Division of Environmental Control Technology

Washington, DC 20545

J. P. Hamric/J. B. Whitsett

DOE Idaho Operations Office

550 2nd St.

Idaho Falls, ID 83401

R. Chitwood

DOE Nuclear Waste Management Programs

NE-341, GTN

Washington, DC 20545

C. R. Cooley/D. G. Boyer

DOE Nuclear Waste Management

Programs

NE-331, GTN

Washington, DC 20545
No. of

Copies

G. H. Daly/J. E. Dieckhoner DOE Nuclear Waste Management Programs

NE-322, GTN

Washington, DC 20545

C. H. George/C. A. Heath

DOE Nuclear Waste Management

Programs

NE-342, GTN

Washington, DC 20545

R. D. Walton

MSB-107

Division of Waste Products

US DOE

Germantown, MD 20545

D. J. McGoff/V. Trice

DOE Nuclear Waste Management Programs

NEW, B-107, HQ

Washington, DC 20545

2 S. Meyers/R. Romatowski

DOE Nuclear Waste Management Programs

NE-30, GTN

Washington, DC 20545

G. Oertel

DOE Nuclear Waste Management

Programs

NE-320, GTN

Washington, DC 20545

3 A. F. Perge/R. W. Ramsey, Jr. DOE Nuclear Waste Management

Programs

NE-301, GTN

Washington, DC 20545 
No. of

Copies

D. L. Vieth

DOE Nuclear Waste Management

Programs

NE-332, GTN

Washington, DC 20545

Office of the Assistant Manager for Energy Research and.

Development

DOE Oak Ridge Operations Office P.0. Box E

Oak Ridge, TN 37830

S. G. Harbinson

DOE San Francisco Operations Office

1333 Broadway

Oakland, CA 94612

2 W. B. Wilson/E. S. Goldberg/

R. P. Whitfield/

T. B. Hindman, Jr.

DOE Savannah River Operations Office

P.0. Box A

Aiken, SC 29801

Los Alamos Scientific Laboratory

P.0. Box 1663

Los Alamos, NM 87544

D. B. Rohrer/R. D. Smith

Division of Waste Management

Nuclear Regulatory Commission

Washington, DC 20555

R. E. Cunningham

Office of Nuclear Safety

Materials and Safeguards

Nuclear Regulatory Commission

Room 562, 7915 Eastern Avenue

Silver Springs, MD 20910

Beverly Rawles

Battelle Memorial Institute

Office of Nuclear Waste Isolation

505 King Avenue

Columbus, $\mathrm{OH} 43201$
No. of

Copies

27 DOE Technical Information Center

J. A. Buckham/A. Williams

Allied-General Nuclear Services

P.0. Box 847

Barnwe11, SC 29812

M. J. Steindler/L. E. Trevorrow/

J. H. Kittel

Argonne National Laboratory

9700 South Cass Avenue

Argonne, IL 60439

W. Carbiener/N. E. Carter

Battelle Memorial Institute

Office of Nuclear Waste Isolation

505 King Avenue

Columbus, $\mathrm{OH} 43201$

Research Library

Battelle Memorial Institute

505 King Avenue

Columbus, $\mathrm{OH} 43201$

R. Maher, Program Manager

Waste Management Programs

Savannah River Plant

E. I. Du Pont de Nemours \& Co.

Aiken, SC 29801

2 M. D. Boersma/H. L. Hull

E. I. Du Pont de Nemours \& Co.

Savannah River Laboratory

Aiken, SC 29801

J. L. Cranda11/R. G. Garvin

E. I. Du Pont de Nemours \& Co.

Savannah River Laboratory

Aiken, SC 29801

L. W. Meyer

E. I. Du Pont de Nemours \& Co.

Savannah River Laboratory

Aiken, SC 29801 
No. of

Copies

D. L. McIntosh/J. Kelley

E. I. Du Pont de Nemours \& Co.

Savannah River Laboratory

Aiken, SC 29801

S. Mirshak

E. I. Du Pont de Nemours \& Co. Savannah River Laboratory

Aiken, SC 29801

G. B. Woolsey

I. E. Du Pont de Nemours \& Co. Savannah River Laboratory

Aiken, SC 29801

A. L. Ayers/G. B. Levin

$E G$ \& G Idaho

P.0. Box 1625

Idaho Falls, ID 83415

R. Williams

Electric Power Research Institute

$3412 \mathrm{Hillview} \mathrm{Avenue}$

Palo Alto, CA 94304

J. L. Larocca, Chairman

Engineering Research and Development Authority

Empire State Plaza

Albany, NY 12223

2 Environmental Protection Agency

Technological Assessment Division (AW-559)

Office of Radiation Programs

U.S. Environmental Protection Agency

Washington, DC 20460

J. R. Berreth

Exxon Nuclear Idaho

P.0. Box 2800

Idaho Falls, ID 83401
No. of

Copies

File Copy

Exxon Nuclear Idaho

P.0. Box 2800

Idaho Falls, ID 83401

J. Campbe11/ J. D. Tewhey

Lawrence Livermore Laboratory

P.0. Box 808

Livermore, CA 94550

R. Roy

202 Materials Research Laboratory

Pennsylvania State University

University Park, PA 16802

C. J. Kershner

Monsanto Research Corporation

Mound Laboratory

P.0. Box 32

Miamisburg, $\mathrm{OH} 45342$

J. P. Duckworth

Plant Manager

Nuclear Fuels Services, Inc. P.0. Box 124

West Valley, NY 14171

R. E. Blanco/J. 0. Blomeke/

D. E. Ferguson/A. L. Lotts/

R. S. Lowrie

Oak Ridge National Laboratory

P.0. Box Y

Oak Ridge, TN 37830

A. B. Mart in

Rockwe 11 International

Energy Systems Group

8900 DeSoto Avenue

Canoga Park, CA 91304

H. Recht

Dept. 737-710

Atomics International Division

Rockwe 11 International

Box 309

Canoga Park, CA 91304 
No. of

Copies

W. S. Bennett/Paul Hagen

Rockwe 11 International

Rocky Flats Plant

P.0. Box 464

Golden, CO 80401

R. G. Kepler/D. R. Anderson

0 . E. Jones/W. Weart

Organic and Electronic Dept. 5810

Sandia Laboratories

Albuquerque, NM 87185

D. E. Harrison

Westinghouse Electric Corp.

P.0. Box 355

Pittsburgh, PA 15230

P. B. Macedo

Keane Hall

Vitreous State Laboratory

The Catholic University of America

Washington, DC 20017

R. G. Post

College of Engineering

University of Arizona

Tucson, AZ 85721

L. L. Hench

Dept. of Materials Science and Engineering

University of Florida

Gainesville, FL 32611

Dr. Hayne Palmour III

2140 Burlington Engineering Laboratories

North Carolina State University

Raleigh, NC 27607

\section{ONSITE}

5 DOE Richland Operations Office

J. J. Schreiber (3)

M. W. Shupe (2)
No. of

Copies

4 Rockwell Hanford Operations

I. E. Reep

D. D. Wodrich

M. J. Kupher

W. W. Schultz

UNC United Nuclear Industries

F. H. Bouse

Westinghouse Hanford Company

A. G. Blasewitz

37 Pacific Northwest Laboratory

W. J. Bjorklund

W. F. Bonner

R. A. Brouns

L. L. Burger

T. D. Chikalla

R. D. Dierks

M. S. Hanson

$F$. E. Haun

L. K. Holton (10)

D. E. Knowlton

C. A. Knox

W. L. Kuhn

L. T. Lakey

D. E. Larson

J. L. McElroy

G. B. Mellinger

R. E. Nightingale

R. D. Peters

D. H. Siemens

R. L. Treat

H. H. Van Tuyl

Technical Information (5)

Publishing Coordination (2) 